\title{
Fekete Rita
}

fekete.rita@lib.pte.hu

Változások és lehetöségek a tudományos publikálásban A tudományos folyóirat-kiadás tendenciái

\section{A tananyagról...}

A tananyag a formális publikációs szinteken történő változásokat veszi górcső alá. A bevezető leckében foglalkozunk a folyóirat-kiadás kezdeteivel és a tudományos közösségek életében betöltött szerepével. Áttekintjük a folyóiratkrízis kialakulásának okait és azokat az igényeket, amelyek előidézték az Open Access Mozgalom irányelveinek megfogalmazódását. Ezt követően bemutatjuk az Open Access Mozgalom törekvéseit, a legfontosabb szereplöket, kezdeményezéseket és dokumentumokat, továbbá részletesen foglalkozunk a tudományos publikálásra gyakorolt hatásaival is. A folytatásban a publikálásban csapdát jelentő predátor kezdeményezések típusait és jellemzöit, valamint a szélhámosok ellen alkalmazható jó gyakorlatokat ismertetjük. Végül igyekszünk összegyüjteni a tudományos lektorálás általános jellemzőit, típusait, valamint a müködésével szemben megfogalmazott kritikákat. A leckékben jelentős szerepet kap a témakörökhöz kapcsolódó fogalmak részletes definiálása. A hallgató a tananyag feldolgozásával új kontextusba helyezheti a tudományos publikálás egészét.

\section{A TUDOMÁNYOS PUBLIKÁLÁS VÁLTOZÁSAI}

\section{Bevezetö gondolatok}

A tananyag válogatott szakirodalom feldolgozásával mutatja be a folyóirat-kiadás szerepét a tudományos kommunikációban. A tudományos akadémiák által gondozott és kiadott folyóiratok megjelenése olyan fórumot biztosított a publikáló akadémikusok számára, amit korábban semmilyen más közlési módszer nem tudott. A 19. század végégig kialakuló kiadási modell évszázadokig változatlanul müködött. S habár a publikálási eljárás nem igazán, de a gazdaság, a kiadói üzletpolitikák, az akadémiai és felsőoktatási intézmények elvárásai és a technológiai lehetőségek változtak. Ezek a változások a 20. század 
közepétől a folyóirat-kiadásra is hatással vannak. A hagyományos folyóirat-kiadásnak egyre több nem kívánt mellékhatása van, amit már a tudományos élet szereplői is kezdenek felismerni. A hallgató a lecke feldolgozása közben válaszokat kap arra, hogy a tudományos közösségek életében miért nélkülözhetetlenek a folyóiratok, hogy milyen kiváltó okai lehetnek az évtizedek óta tartó folyóiratkrízis kialakulásának, és milyen igények megfogalmazása mentén vált egyértelmüvé a paradigmaváltás szükségessége.

\section{Célok, megszerezhetö kompetenciák}

A leckében összegzett elméleti ismeretek átfogó képet nyújtanak a tudományos szakfolyóiratok szerepéröl. A tananyag olyan összefüggésekre világít rá, melyek a kurzus során a későbbi leckék elsajátításának alapját képzik és hasznosak az ok-okozati viszonyok megértésében. A lecke mindenekelőtt a résztvevő kritikai gondolkodásmódját fejleszti.

Szükséges eszközök, források

Jól müködő asztali vagy hordozható számítógép és internetkapcsolat.

Feldolgozási idö

- 90 perc

\section{Témakörök}

- Bevezetés

- A tudományos közösségektől a folyóirat-kiadásig,

- A folyóiratkrízis kialakulásának okai

- A hagyományos kiadási modell buktatói és új eszmék a születése

- A lecke ismeretlen fogalmainak magyarázata

\section{Irodalmak}

- Ana Maria Ramlho Correia, José Carlos Teixeira: Reforming scholarly publishing and knowledge communication. From the advent of the scholarly journal to the challenges of open access. = A tudományos publikálás és kommunikáció megújulása/ Tóth Máté (ford.). In: Tudományos és Müszaki Tájékoztatás vol. 53. iss. 10. pp. 471473. http://bit.ly/3rRIXlt"

- A szövegben előforduló összes internetes hivatkozás letöltési és ellenőrzési dátuma 2021. május 1. 
- Bikádi Katalin: Trendek a tudományos publikálásban. In: Orvosi könyvtárak: a Magyar Orvosi Könyvtárak Szövetségének hivatalos lapja vol. 11. iss. 2. pp. 11. 2014. http://bit.ly/2OUqki4

- Nancy Fjällbrant: Scholarly Communication - Historical Development and New Possibilities. In: Proceedings of the IATUL Conferences. 1997. Paper 5. http://bit.ly/2Nj4dSd

- Sipos Anna Magdolna: A folyóiratkrízisről. A szakfolyóiratok kiadási modelljének változásairól és áremelkedési tendenciáról könyvtáros szemmel. 1. rész. In: Könyvtári Figyelő vol. 63. iss. 1. pp. 9-30. 2017. https://bit.ly/3qHyHec

- Tomasz Gábor: Átalakulóban a tudományos folyóiratok kiadási modellje. In: Educatio vol. 22. iss. 3. 2013. https://bit.ly/3lkBjhc

- Varga Máté: A tudomány publikációs válsága (és egy lehetséges kiút). In: sciencemeetup.444.hu 2016. április 4. http://bit.ly/3bMqKA2

- Világok harca - Kutatók vs. Elsevier. In: criticalmass.blog.hu 2012.02.12. http://bit.ly/2Q5yViI

\subsection{Bevezetés}

A folyóirat-kiadás kezdetei a 17. századig vezethetők vissza. Két kiadási modellt különböztethetünk meg, melyek közül, az egyik a magántulajdonú kiadóivállalkozásokkal, a másik az akadémiák létrejöttével hozható összefüggésbe. Az első európai tudományos folyóiratokat 1665-ben adták ki. A francia Journal des Scavans Denis de Sallo alapításában, magánvállalkozás keretében jelent meg 1665 januárjában. Még ez év márciusában a brit Royal Society is kiadta a Philosophical Transactions.` A Royal Society mintájára a legtöbb akadémia, mintegy két évszázaddal később pedig a nagyobb egyetemek is megkezdték a saját tudományos folyóirataiknak a kiadását. Több száz éven át ezek az intézményesült tudományos, kutatói közösségek voltak azok, akik uralni tudták a tudományos folyóiratkiadást. A kereskedelmi kiadói vállalatoknak csupán csak a 20. században sikerült igazán teret nyerniük. A folyóiratok szerepének felértékelődésével, vagyis a tudományos mérőszámok megjelenésével szinte egy időben kiaknázták a lehetőségeiket és megerösítették a pozíciójukat. Hibás lenne azt a következtetést levonni, hogy a tudományos publikálás változásának hátterében egyetlen szereplő, mégpedig a kiadóvállalatok állnak. Tény, hogy profitorientált szemlélet módjuk erősen befolyásoló tényezőként van jelen, mégis ki kell hangsúlyoz-

- A folyóiratok digitalizált változatai a következő úton érhetőek el: https://bit.ly/3rOGacR / https://bit.ly/3lj5uFb 
nunk, hogy a tudományos közösségeknek ugyanakkora felelösségük van a publikálási modell változásaiban. ${ }^{1}$

\subsection{Tudományos kommunikáció}

\section{A tudományos kommunikáció szintjei}

Tudományos kommunikáció ${ }^{2}$ alatt a kutatási módszerek és eredményeik széles körben történő áramlását értjük. A tudományos kommunikációban (1) informális kommunikációs és (2) formális publikációs szintet szokás megkülönböztetni. Az informális kommunikáció általában intézményesült keretek nélkül alakul ki az adott tudományvagy szakterület képviselői között. Lehet verbális vagy írott formája is. Előbbi általában személyes kapcsolatok révén konferenciákon, szemináriumokon, előadásokon, de akár értekezleteken és megbeszéléseken is kialakulhat. Utóbbi általában a levélváltásokat vagy a személyes kapcsolattartásra alkalmas archiválható módszereket jelenti, például webinárokat. Előnye az információ gyors, szinte azonnali terjedése és a könnyü használata. Ugyanakkor nem minden formája alkalmas a széleskörü tájékoztatásra. Az információ csere ezen a szinten általában zárt közösségek között zajlik. A formális publikációs szint egészen az elektronikus kiadványok megjelenéséig hagyományosan a nyomtatott anyagokat jelentette. Ma már az internet segítségével elérhető előfizethető és vásárolható elektronikus folyóiratokat és könyveket is ide sorolhatjuk. Tehát tulajdonképpen kiadásban megjelent írott, ingyenes, előfizethető vagy megvásárolható tartalmakról beszélünk, melyek szakmai ellenőrzésen, vagyis lektoráláson estek át. Képes a tudományos közösségek széleskörű tájékoztatására. Biztosítja a részletes információátadást: kutatási módszer, elemzések, összehasonlítások, eredmények, illusztrációk, a kutatási adatok táblázatos vagy diagramos megjelenítése. Könnyen hivatkozható, ami egyes tudományterületeken jelentős szerepet játszik a kutatók szakmai megítélésében.

1 Schubert András: A folyóirat-kiadás szereplöi a társadalom- és orvostudományokban. In: Orvosi Hetilap vol. 156. iss. 16. pp. 650-653. 2015. http://bit.ly/3eELnjK

2 Nancy Fjällbrant: Scholarly Communication - Historical Development and New Possibilities. In: Proceedings of the IATUL Conferences. 1997. Paper 5. http://bit.ly/2Nj4dSd 


\section{A tudományos folyóirat publikálás kezdetei}

A folyóiratok, ahogy napjainkban úgy a 17. században sem voltak egyeduralkodók. A tudományos kommunikációnak léteztek más formái is. Ilyenek voltak a tudósok közti (sokszor rejtjeles szövegezéssel küldött anagrammák) levelezések, amikre azért volt szükség, hogy a szerzők titokban tudják tartani az eredményeiket, ezáltal megőrizve a kutatási elsőséget, továbbá a szakkönyvek és az újságok.

Ezek közül egyértelmủen az anagrammák, vagyis a rejtjeles szövegezések és a tudósok közti levelezések voltak leginkább alkalmatlanok a tudás széleskörü terjesztésére, vagyis a tudomány egészének nemzetköziesedésére. Ugyanakkor ez nem jelenti azt, hogy nem volt erős hatásuk a tudományos diskurzusokban. Néhány folyóirat még napjainkban is kizárólag „letter” típusú publikációkat közöl. A szakkönyvek a folyóiratokhoz képest szintén alkalmatlannak bizonyultak a legfontosabb igények kielégítésére. Egyrészt költséges volt az elöállításuk és sokba került a beszerzésük, másrészt időigényes volt a megjelentetésük, ami megint csak ahhoz vezetett, hogy a szerzők nem tudták az elsőségre fenntartott igényeiket érvényesíteni. A könyvek kapcsán két dolgot fontos kiemelnünk. Az egyik, hogy a könyv, mint fontos információhordozó eszköz nem vesztett a jelentőségéből. A természettudományokban, azon belül is a fizika területén a 18. századtól egészen a 19. század közepéig a folyóiratcikkek mellett meglehetősen népszerü volt a legfontosabb kutatási eredményeket tudományos monográfiák formájában is közölni. Mi sem bizonyítja ezt jobban, mint hogy a tudóstársaságok a folyóiratok mellett könyvek kiadásával is foglalkoztak. A másik, hogy bizonyos tudományterületeken még ma is fontos szerepük van a szakkönyveknek, hiszen a könyvben történő publikálás más közlési céllal, más funkciók betöltésére alkalmas, mint a folyóiratokcikkek, ezért összehasonlításuk nehézkes és helyenként erőltetett is lehet.

Néhány mondatban érdemes összegezni azokat az igényeket, amelyek kielégítésével a tudományos folyóiratok a legtöbb tudományterületen a formális publikálás elfogadott és leginkább preferált módjává váltak. A (1) szerzők igényeit a következőképpen fogalmazhatjuk meg: a tudományos elsőség, a szakterületi kutatások eredményeinek „tulajdonjoga” iránti kívánalom. A tudományos ismeretek megosztása a nemzetközi tudós közösségek között. Bizonyos eredmények kereskedelmi hasznosításának a lehetőségei. A rendszeres és lehetőség szerinti gyors megjelenés, valamint a hozzáférés biztosítása. Továbbá a minőségi ellenőrzés lehetősége. A (2) kereskedelmi és az akadémiák által múködtetett kiadók számára a minőségi szempon- 
toknak történő megfelelés, illetve az olcsó és gyors előállítás volt az elsődleges cél.

A folyóiratok a gyors megjelenéssel és a magasabb példányszámmal lehetővé tették, hogy a szerzők megszerezzék magunknak a kívánt nemzetközi hírnevet. Periodicitása garantálta a naprakész és rendszeresen történő információátadást. Képes volt egy szakterületen belül többféle kutatási kérdés eredményeinek összegyüjtésére. A tudós társaságok gondozásában megjelent publikációk pedig minőségi védjegyet hordoztak magukon.

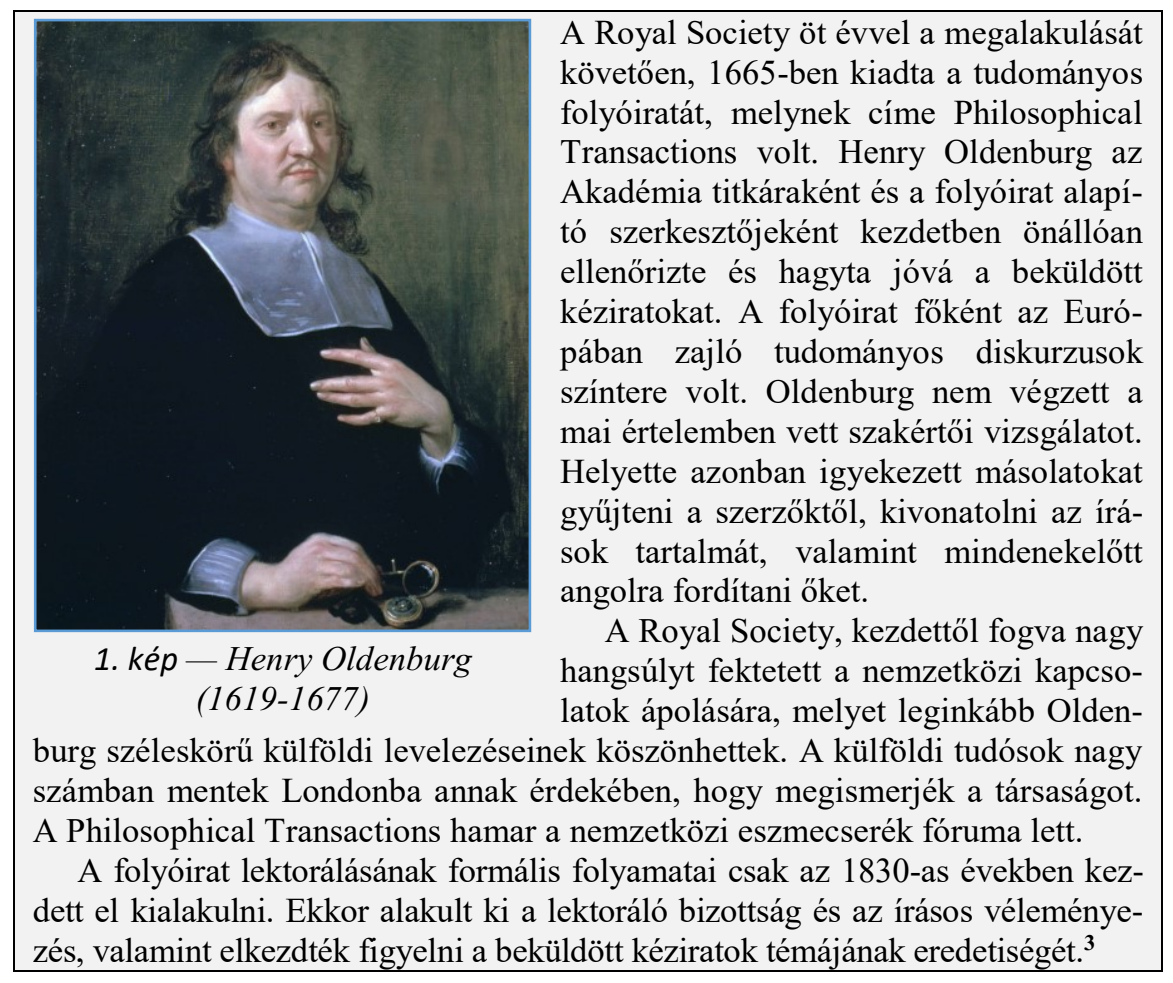

\subsection{A folyóiratkrízis kialakulásának okai}

Hiba lenne azt állítani, hogy három évszázad alatt nem történt változás a folyóirat-kiadásban. Azonban ezek az átalakulások elsősorban nem a kiadás modelljére - amivel a tananyagunk foglalkozik -, ha-

3 Alice Meadows: Journals Peer Review: Past, Present, Future. In: The Scholarly Kitchen 2017. szept. 14. http://bit.ly/3eF5fmU; Kornis Gyula: Az akadémiák. In: Tudomány és társadalom. A tudomány szociológiája 1. kötet. Budapest: FranklinTársulat, 1944. pp. 431-440. 
nem a technika fejlődésében voltak érzékelhetők. A folyóirat-kiadás válságának első jelei már az 1960-as évek óta megfigyelhetőek. A II. világháborút követően megnőtt a kutatási aktivitás és a kutatók száma is. Az Amerikai Egyesült Államokban szintén ebben az időszak kezdtek nagy hangsúlyt fektetni a felsőoktatás és a tudományos kutatások állami támogatására. Ennek következtében több felsőoktatási intézmény státusza kutató egyetemmé alakult át. Az aktív kutatói munka eredménye a publikációk növekedéséhez vezetett, melyek megjelentetése egyre nagyobb költségekkel és több munkával járt, ezzel párhuzamosan az átfutási idő is hosszabb lett, ami a közlésben jelentett késéseket. A kereskedelmi kiadók hamar realizálták a helyzetet és sok tudományos akadémia gondozásában lévő folyóirat kiadását vállalták át, a meglévő folyóiratok mellett pedig újakat hoztak létre. A tudományos folyóirat-kiadás megtérülő befektetésnek bizonyult. Az 1980-as évekre a ma is ismert legnagyobb nemzetközi kiadók fúziók révén monopolhelyzetbe kerültek. Legnagyobb bázisukat a természettudományi, müszaki, valamint orvostudományi (STM-science, technology, medical) területekről merítették. ${ }^{4}$

„Az 1980-as évekre a tudományos folyóiratcikkek 42\%-át 3 kiadói csoport, a Reed Elsevier, a Wiley és a Springer adta ki. Ilyen mértékü piaci dominanciájuk torzulást okozott mind az előfizetési árakban, mind a tudományos folyamatokban. A Nobel-díjas Randy Schekman kiáltványszerü cikkben hívta fel a közvélemény figyelmét az utóbbi torzulásokra, majd bejelentette, hogy emiatt laboratóriuma a továbbiakban nem publikál a Nature, Cell és Science folyóiratokban."5

Mindezen állítások mögött van néhány érdekes jelenség, amit a folyóiratkrízis jellemzőiként tartanak számon, s amivel érdemes mélyrehatóbban foglalkoznunk annak érdekében, hogy megértsük hogyan jutottunk el a tudományos publikálás megújítására törekvő eszmékig.

4 Ana Maria Ramlho Correia, José Carlos Teixeira: Reforming scholarly publishing and knowledge communication. From the advent of the scholarly journal to the challenges of open access. = A tudományos publikálás és kommunikáció megújulása Tóth Máté (ford.). In: Tudományos és Müszaki Tájékoztatás vol. 53. iss. 10. pp. 471-473. 2006. http://bit.ly/3rRIXlt; Börzsönyi Nóra: Hozzáférhető tudomány: Az open access és az értéknövelt publikációk világa a könyvtári gyakorlat tükrében. https://bit.ly/2Oyqb43

5 Bikádi Katalin: Trendek a tudományos publikálásban. In: Orvosi könyvtárak: a Magyar Orvosi Könyvtárak Szövetségének hivatalos lapja vol. 11. iss. 2. pp. 11. 2014. http://bit.ly/2OUqki4 


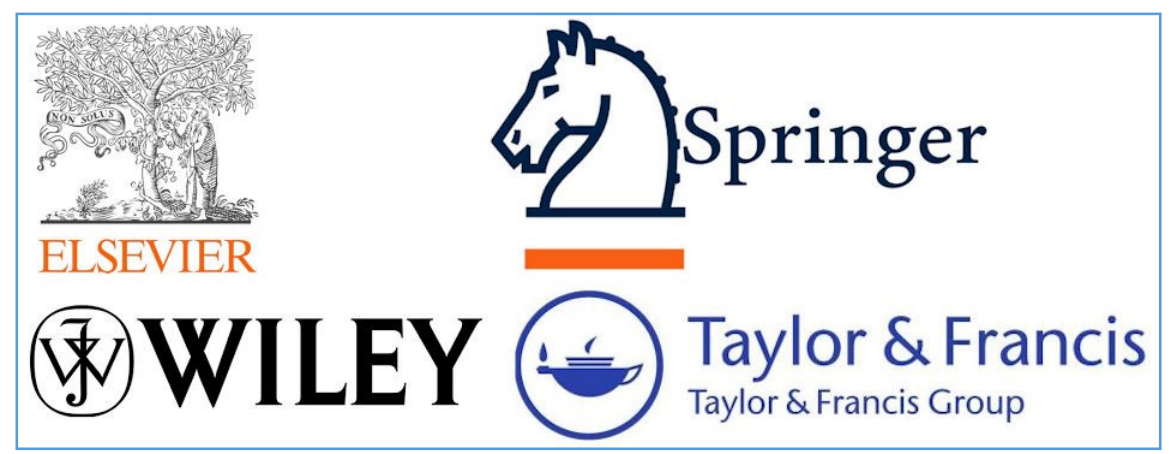

2. kép - A legismertebb nemzetközi kiadók

\section{A folyóiratok szerepének felértékelödése}

Az internet megjelenése elött a tudományos közlés naprakészségét a folyóiratok periodicitása garantálta. Mindenkori aktualitása mellett ez biztosította a nyilvános kommunikációt a különböző régiókban élő tudós közösségek között. Az akadémiák által közreadott folyóiratok már a lektorálás kialakulása előtt is szakmailag megbízható fórumként voltak számon tartva. A hozzájuk rendelt népszerüségi- valamint presztízsmutatók megjelenése (a kiadók nagy örömére) még inkább felértékelte a szerepüket. Aligha fogunk találni olyan pályázati kiírást, ahol nem kérik számon az impakt faktor vagy kvartilis értékkel rendelkező publikációk számát.

„Egyrészről a kutatók olyan, a szakmai presztízsüket, előmenetelüket, boldogulásukat nagymértékben meghatározó fórumokként kezelik azokat, amelyek publikációs lehetőséget is biztosítanak számukra, másrészről pedig ezek révén hozzájuthatnak a kutatásaikhoz feltétlenül szükséges friss információkhoz, amelyek nélkül munkájukat, kutatásaikat nem tudják folytatni."”

\section{A publikációs kényszer}

Bizonyára mindenki hallotta már a publikációs kényszerrel azonosított jelmondatot: „Publish or Perish!”, magyarul „Publikálj vagy pusztulj!”. Közhelyesnek hangzik a régóta és sokat emlegetett szlogen, de eddig még senki nem talált olyat, ami ennél érthetőbben és rövidebben írja le a szerzőkre nehezedő nyomást. Hazánkban a doktori iskolák az abszolutórium és a fokozat megszerzéséhez is a szükséges követelmé-

6 Sipos Anna Magdolna: A folyóiratkrízisről. A szakfolyóiratok kiadási modelljének változásairól és áremelkedési tendenciáról könyvtáros szemmel. 1. rész. In: Könyvtári Figyelö vol. 63. iss. 1. pp. 26. 2017. https://bit.ly/3qHyHec 
nyek között határozzák meg, hogy a hallgatóknak milyen publikációs teljesítménymutatókkal kell rendelkezniük. A doktori iskola elvégzését követően a pályán elhelyezkedett, aktív kutató, tudós számára nincs megállás. Munkájuk minőségét és szakmai sikerességüket a publikációik és a rájuk történő hivatkozások számában mérik.

„A megjelentetésre szánt közleményözönt részben az egyéni ambíciók fütik, részben pedig a tudósok teljesítményeire is ható külső kényszerek okozzák. Az utóbbiak közül most csupán a legfontosabbakat emeljük ki. A nemzetközi szinten történő, a kvantálhatóságra alapozott személyi és intézményi minősítések, valamint a hozzájuk kapcsolódó anyagi és szakmai egzisztenciális, illetve presztízs kérdések, az egyetemi rangsorolásokhoz, a kutatásokhoz ma már szorosan hozzátartozó egyéni és csoportos pályázatok. Mindezek együttesen meglódították a publikációk számát, amely azonban több nemkívánatos jelenséget is magával hozott. Ilyenek például az egy publikációra eső szerzők számának növekedése, a szerzői státusz és tekintély inflálódása, a publikációk tartalmának felhígulása, a lektorálás felszínessé, felületessé válása, a publikációk tartalmi hibái, hiányosságai, a hanyagul kezelt hivatkozások, a plagizálás, a hivatkozásokkal történő manipulációk, a folyóiratok minősítésének mesterséges úton való feljavítására irányuló machinációk, a csalások (mint például a parazita folyóiratok megjelenése), és a sort az ezekkel a kérdésekkel foglalkozók saját tapasztalataik alapján bizonyára tovább is tudnák bővíteni."”

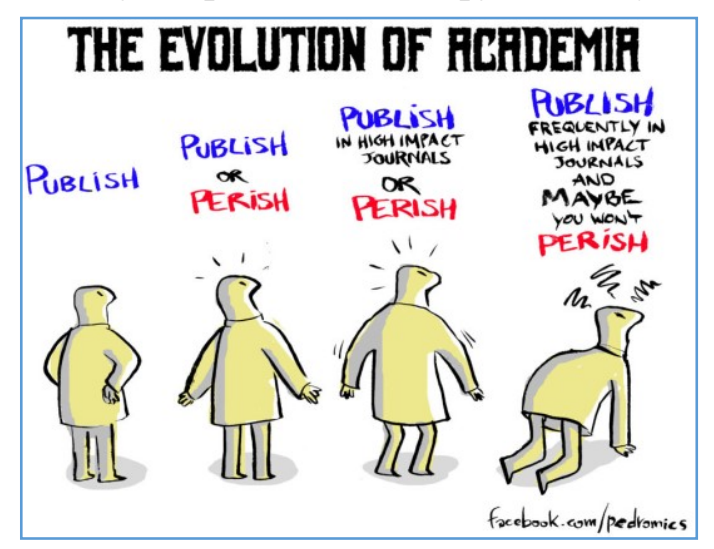

Több, eddig egyelöre megválaszolatlan, de jogosnak ítélhető kérdés is felmerül a ,publish or perish" iránymutatása kapcsán. Meddig tarthatóak és elégíthetőek ki ezek a publikációs elvárások? Ilyen nyomás alatt tud-e jól müködni a publikálási rendszer? Hol a határ?

7 Sipos Anna Magdolna: A folyóiratkrízisről. A szakfolyóiratok kiadási modelljének változásairól és áremelkedési tendenciáról könyvtáros szemmel. 1. rész. In: Könyvtári Figyelö vol. 63. iss. 1. pp. 11. 2017. https://bit.ly/3qHyHec 


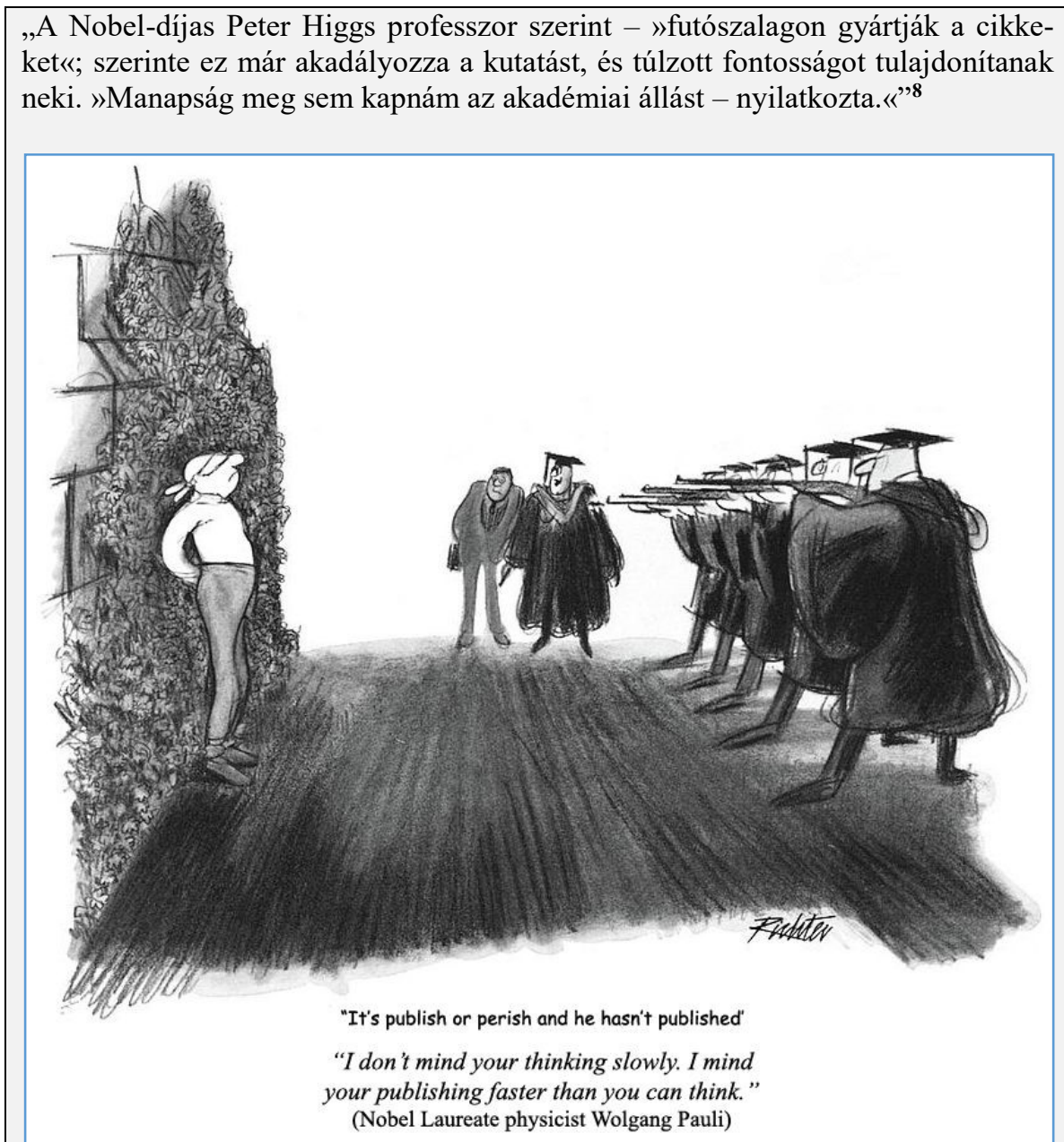

A folyóiratok számának növekedése

Korántsem biztos, hogy a folyóiratok széleskörü választékának kedvező hatása van a tudományos publikálás világára. A legtöbb szerzőnek már a pályája elején kialakulnak a publikációs szokásai. Ennek befolyásoló tényezői között lehetnek a következő szempontok: hol publikálnak a mentorai és társszerzői; melyik a szakterülete által nagy történeti múltra visszatekintő, elismert, és lehetőség szerint tudománymetriai mutatóval rendelkező folyóirat. Mindez azt jelenti, hogy - érthető módon - a szerzők nem használják ki a rendelkezésükre álló

8 Bikádi Katalin: Trendek a tudományos publikálásban. In: Orvosi könyvtárak: a Magyar Orvosi Könyvtárak Szövetségének hivatalos lapja vol. 11. iss. 2. pp. 10-11. 2014. http://bit.ly/2OUqki4 
összes folyóiratot. Valójában a szakterületek meghatározó folyóiratai és az abban publikáló szerzők között folyik a tényleges verseny az eredetiség és elsőség szempontjából. Azonban a növekvő választék a szakmai bírálati rendszerek differenciálódásával és a népszerüségük földrajzi megosztottságával veszélyforrást jelenthet a minőség fenntartásában is. ${ }^{9}$

„Az UNESCO periodikákra vonatkozó nyilvántartását végző ISSN-Központ (International Identifier for Serials International Centre) 2015-ben 1118940 élő ISSN-rekordot tartott nyilván, az éves gyarapodás, vagyis az újonnan induló időszaki kiadványok száma pedig 60-70 ezer körül mozog."10

„A folyóiratok számának növekedése és más tényezők, különösen a világháló tudományos célú alkalmazása révén az utóbbi években a gyorsulás jelei tapasztalhatók a publikálás mennyiségében is. Például míg 2003-ban a tudományos publikációk száma mintegy 1,3 milliót tett ki, addig 2013-ra ez a mennyiség csaknem megduplázódott, 2,4 millióra emelkedett, ami éves átlagban 110 ezres gyarapodást (mintegy 8-8,5\%) jelent. Ennek okát az International Association of Scientific, Technical and Medical Publishers nemzetközi szervezet a kutatók létszámának növekedésében látja, ami - attól függően, hogy hol húzzuk meg a kutatói kategória határait - globálisan 7 és 9 millió között mozog."11

\section{A folyóiratok árának növekedése}

A leckének nem célja feltárni, hogy miért emelkednek folyamatosan a tudományos folyóiratok előfizetési díjai, ezt csupán a folyóiratkrízis kialakulása és tetőzése egyik kiváltó, valamint fenntartó okaként említi. Ugyanakkor röviden, két egyszerü összefüggést érdemes megemlítenünk. Az első szerint a kiadók valójában felismerték, hogy a kutatók igénye olyan erős a nemzetközi tudományos tartalmak iránt, amiböl érdemes hasznot húzniuk. A második szerint nem a folyóiratot vagy a kiadásával járó költségeket fizetik meg az intézmények, hanem a folyóiratok brandjét és presztízs értékét. ${ }^{12}$

A folyóirat-kiadás résztvevőinek körében közismert tény, hogy a legnagyobb nemzetközi kiadócég, az Elsevier évente megközelítőleg

9 Tomasz Gábor: Átalakulóban a tudományos folyóiratok kiadási modellje. In: Educatio vol. 22. iss. 3. pp. 354. 2013. https://bit.ly/3lkBjhc

10 Sipos Anna Magdolna: A folyóiratkrízisről. A szakfolyóiratok kiadási modelljének változásairól és áremelkedési tendenciáról könyvtáros szemmel. 1. rész. In: Könyvtári Figyelő vol. 63. iss. 1. pp. 12. 2017., uő. pp. 17.

11 Uott. https://bit.ly/3qHyHec

12 Kolozsi Ádám: A kazah kalózlány esete a forrongó tudósokkal. In: index.hu 2016.06.17. http://bit.ly/30GhFTa; Tomasz Gábor: Átalakulóban a tudományos folyóiratok kiadási modellje. In: Educatio vol. 22. iss. 3. pp. 355. 2013. https://bit.ly/31kBjhc 
40\%-os haszonkulccsal dolgozik, mint ahogy az is, hogy a kiadók által megnövelt elöfizetési díjakat olyan nagyobb egyetemek is képtelenek finanszírozni mint a Harvard vagy a Cornell. ${ }^{13}$

„A Harvard 2012-ben 3,5 millió dollárt fizetett a folyóirat-előfizetésekért összesen, és már akkor panaszkodott, hogy ez fenntarthatatlan helyzet. A Harvard akkori belső feljegyzésében az állt, hogy az online elérhető cikkek ára az azt megelőző hat évben 145 százalékkal nőtt, ami nemcsak az általános fogyasztóiárindex alakulásánál volt jelentősen nagyobb, hanem a felsőoktatási szolgáltatások és a könyvtári szolgáltatások árindex-alakulásánál is."14

A kiadók kissé megtévesztő módon olyan "kihagyhatatlan" ajánlatokat kínálnak az intézményeknek, melyek keretében valójában folyóiratcsomagokat állítanak össze. Ennek következtében az egyetemek és a kutatóintézetek fontos és nélkülözhetetlen folyóiratok mellett olyanokra is kénytelenek előfizetni, amit alig vagy szinte egyáltalán nem fognak használni.

„Ennek a hozzáállásnak a bicskanyitogató pofátlanságát David Colquhoun, a University College London (UCL) egyik professzora részletezte pár hónapja a blogjában: a UCL az Elsevier 2068 lapjára fizet elő évi 1.25 millió euró értékben. Ha csak a legolvasottabbakat nézzük, akkor jól látható, hogy évi sok tízezres olvasottsággal azok nyilvánvalóan fontos kellékei az egyetem falai között zajló akadémiai életnek. Azonban, ha azt nézzük, hogy átlagosan hányszor olvassák az Elseviercsomagban levő lapokat („Average” az alábbi ábrán), akkor már azt látjuk, hogy alig pár ezerszer (ami egy UCL méretü egyetem esetében nagyon kevés).”

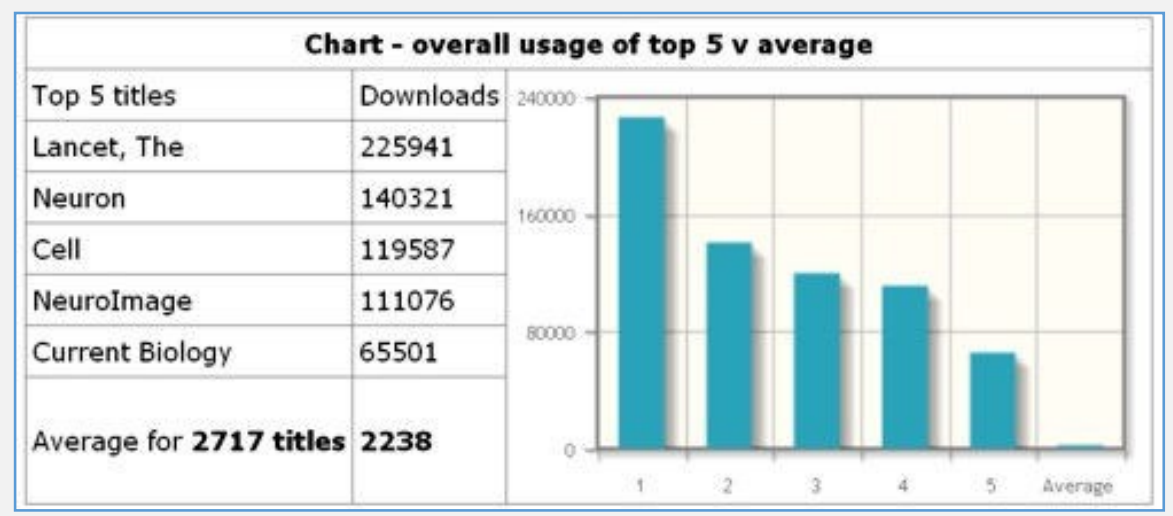

Az előfizetett lapok közül 251-et sosem nyitott meg senki az egyetemen, és a lapok 60\%-át kevesebb mint 300 alkalommal, ami aligha tenné indokolttá az előfi-

13 Varga Máté: A tudomány publikációs válsága (és egy lehetséges kiút). In: sciencemeetup.444.hu 2016. április 4. http://bit.ly/3bMqKA2

14 Bátorfy Attila: 47 millió cikket lopott eddig el, hogy ingyenesen közzétegye öket. In: vs.hu 2016. február 19. http://bit.ly/3lsZlXr 
zetést. De, mint említettem, az Elsevier nem teszi lehetővé csak egyes lapok lemondását, ha valaki túl sokat reklamál, a teljes előfizetést megvonja. Hiába szeretne az egyetem lényeges pénzt megspórolni ezen, nem teheti."15

\section{Adatok az áremelkedésről:}

„Az International Association of Scientific, Technical and Medical Publishers 2013-ra vonatkozó beszámolója szerint önmagában az angol nyelvü STM (science, technology, medical - természettudományi, müszaki, orvosi) szakfolyóiratpiac éves árbevétele mintegy 10 milliárd dollárt tesz ki. A piac növekedésének ütemét jól szemlélteti, hogy 2008-ban ez az összeg még csak 8 milliárd dollárra rúgott, vagyis öt év alatt 2 milliárddal, mintegy $20 \%$-kal emelkedett." 16

\subsection{A hagyományos kiadási modell buktatói, amik új irányelvek eszméinek a megszületéséhez vezettek}

\section{A tudományos közösségek szereplöi}

\section{A felsöoktatási intézmények és könyvtárak már nem tudnak és nem is akarnak ennyit fizetni}

A folyóiratkrízis, melynek kezdetei egészen a 20. század közepére vezethetők vissza egyelőre szünni nem akaró jelenségnek látszik. A felsőoktatási szférában müködő intézmények (főiskolák, könyvtárak, kutatóintézetek) számára egyre nagyobb kiadási költséget jelent előfizetni az időszaki kiadványokra és a szakirodalmi adatbázisokra. Lássuk be, hogy a legtöbb felsőoktatási és szakkönyvtár tudományos folyóiratok előfizetése nélkül (akár nyomtatott akár elektronikus formátumról beszélünk) nehezen vagy egyáltalán nem tudja ellátni a profiljához tartozó feladatokat.

„Az elmúlt évtizedekben azonban valami elromlott és ahogy napjaink egyik legendás genetikusa, Alfonso Martinez-Arias fogalmaz, a tudományos újságkiadás a kutatók publikálását elősegítő médiumból egy fogyasztói termékké változott, ami nem kiszolgálja a kutatókat, hanem ki- és felhasználja azokat az üzleti modelljéhez. Ráadásul paradox módon úgy történt mindez, hogy napjaink technológiájával szinte teljesen megkerülhetővé vált a kiadók szerepe."17

15 Világok harca - Kutatók vs. Elsevier. In: criticalmass.blog.hu 2012.02.12. http://bit.ly/2Q5yViI

16 Sipos Anna Magdolna: A folyóiratkrízisről. A szakfolyóiratok kiadási modelljének változásairól és áremelkedési tendenciáról könyvtáros szemmel. 1. rész. In: Könyvtári Figyelő vol. 63. iss. 1. pp. 14. 2017. https://bit.ly/3qHyHec

17 Varga Máté: A tudomány publikációs válsága (és egy lehetséges kiút). In: sciencemeetup.444.hu 2016. április 4. http://bit.ly/3bMqKA2 
A probléma világméretü, de nagyon úgy fest, hogy patthelyzet állt elö. Az intézményeknek továbbra is szükségük van a tudományos tartalmakra, viszont a kiadók továbbra sem változtatnak agresszív üzleti politikájukon.

\section{A hagyományos kiadási modell hátrányai a kutatók számára}

A tudományos közösség tagjait számos szempont szerint lehetne csoportosítani. A teljesség igénye nélkül gondoljuk végig, hogy az intézmények demográfiai és gazdasági helyzete, valamint a szerzők életkor- és tudományterület-szerinti vizsgálata, akár egy önálló tanulmány kutatási kérdésköre is lehetne. Ebben a leckében erre nem vállalkozunk. Már csak azért sem, mert a tágabb kontextusban megfogalmazott problémák elegendő információval szolgálnak és érhetővé teszik a hagyományos kiadási modell gyengeségeit.

A jelentősebb kutatási eredményekhez történő hozzáférés hiánya, ami leginkább a korábban már említett magas előfizetési díjakból adódik, megnehezíti a kutatók munkáját, főleg olyan kutatási területeken, ahol naprakész információkra lenne szükség. A hozzáférési korlátok miatt egy fejlődő országban tevékenykedő kutatócsoport például könnyüszerrel lemaradhat vagy - ami még rosszabb - kimaradhat a kutatásokból. Tomasz Gábor Atalakulóban a tudományos folyóiratok kiadási modellje c. cikkének egyik fejezetében jól ismerteti ezt a problémakört, ami leginkább a fejlődő országok kutatóit érinti. Ezeknek a kutatóknak nehéz bejutniuk a nyugati szaklapokba, ha mégis sikerül, akkor általában az intézményeik nem tudnak előfizetni arra a folyóiratra vagy folyóiratcsomagra, amiben a cikkeik megjelennek.

A publikálás világában bizonyos értelemben meglehetősen zárt közösségek, valamint igen erős hagyományok és hierarchiarendszerek müködnek. A kiadóknál hosszú időt kell várni egy cikk bírálatára, a szerkesztőbizottságok sokszor ugyanazokat a szerzőket részesítik előnyben, a lektorálás egyes szintjei ugyancsak manipulálhatják a tudományos közlések kiadásának alakulását.

Mindig is léteztek olyan „láthatatlan egyetemek”, melyeknek tagjai nem várták meg a publikáció megjelentetési folyamatának a végét. Helyette lektoráltan kéziratok formájában osztották meg egymással a kutatási eredményeket. A technológia fejlődése, egészen konkrétan az internet megjelenése hatékony platformot biztosított (és biztosít) ennek a módszernek. 
A publikáló szerzők és a lektorok nem részesülnek juttatásban. Az idő előrehaladtával a közvetett haszon számukra továbbra is a karrierjükben bekövetkező elörelépés lehetőségében rejlik.

A hagyományos publikálási modellben a szerzői jogok teljes mértékben a kiadókhoz kerülnek. Ez nem egy szerencsés állapot föleg nem abban az esetben, ha a szerző azt szeretné, hogy minél többen hivatkozzanak müvére. ${ }^{18}$

\section{A tudás mindenkié, de leginkább azé, aki fizet érte}

Igazán szép eszméje a tudományos kommunikáció forradalmárainak az, hogy az államilag („közpénzből”) finanszírozott kutatási eredmények köztulajdont képeznek, emiatt teljesen érthetetlen, hogy pont az adófizetők azok, akik nem férnek hozzá azokhoz az eredményekhez, melyeket valójában ők fizettek. Korábban a folyóiratok megjelentetésének igen magas elóállítási és kiadási költségei voltak, amiket valakinek meg kell térítenie. Ugyanakkor ne feledjünk két fontos tényt: az egyik, hogy a lektorokat és a szerzőket anyagilag nem (vagy nem minden esetben) honorálják a kiadók. A másik, hogy az internet megjelenésével és a technológia fejlődésével minimálisra csökkent a folyóiratok előállítási költsége. Azaz, ma már leginkább a kiadó nevét és a folyóirat presztízsértékét fizettetik meg azokkal az állami tulajdonban lévő felsőoktatási intézményekkel, könyvtárakkal és kutatóintézetekkel, amiket az adófizető állampolgárok pénzéből tartanak fent. ${ }^{19}$

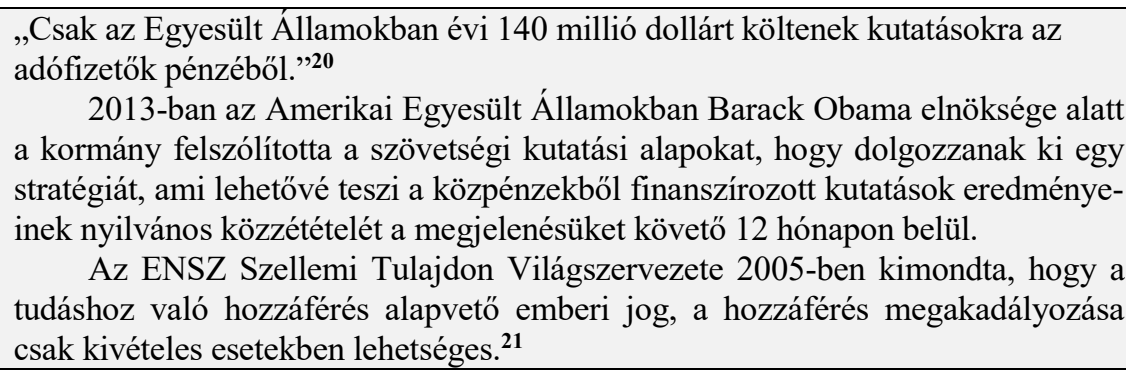

2013-ban az Amerikai Egyesült Államokban Barack Obama elnöksége alatt a kormány felszólította a szövetségi kutatási alapokat, hogy dolgozzanak ki egy stratégiát, ami lehetővé teszi a közpénzekből finanszírozott kutatások eredményeinek nyilvános közzétételét a megjelenésüket követő 12 hónapon belül.

Az ENSZ Szellemi Tulajdon Világszervezete 2005-ben kimondta, hogy a tudáshoz való hozzáférés alapvető emberi jog, a hozzáférés megakadályozása csak kivételes esetekben lehetséges. $^{21}$

18 Tomasz Gábor: Átalakulóban a tudományos folyóiratok kiadási modellje. In: Educatio vol. 22. iss. 3. pp. 358-359. 2013. https://bit.ly/3lkBjhc

19 Horváth Bence: Fellázadtak a német egyetemek és könyvtárak a szabad tudásért. In: 444.hu 2016. december 22. http://bit.ly/2OV1SgM

20 Bátorfy Attila: 47 millió cikket lopott eddig el, hogy ingyenesen közzétegye öket. In: vs.hu 2016. február 19. http://bit.ly/31sZlXr

21 Tomasz Gábor: Átalakulóban a tudományos folyóiratok kiadási modellje. In: Educatio vol. 22. iss. 3. pp. 356. 2013. https://bit.ly/3lkBjhc 


\subsection{A lecke ismeretlen fogalmainak magyarázatai}

\section{A folyóiratok teljesitménymutatói}

A folyóiratok rangsorolására alkalmas mutatók. A jelenleg elterjedt mérőszámok a folyóirat közleményeinek idézettségén alapulnak. Az egyes mérőszámok között erős korreláció figyelhető meg. A teljesítmény szempontjából megkülönböztetünk népszerüségi és presztízsmutatókat. Előbbi kategóriába tartozik például a sokak által jól ismert impakt faktor (IF), míg utóbbiba a SCImago Journal Rank (SJR). ${ }^{22}$

\section{Impakt faktor}

„Az impakt faktor (IF) a Clarivate Analytics által indexelt folyóiratok tudományos színvonalának fokméröje: megmutatja, hogy adott folyóirat cikkeit más folyóiratok milyen mértékben idézték. Az IF érték a folyóirat hatásmutatója, melyből a tudományos közösség hajlamos az adott cikk (és szerző) minőségére következtetni, helytelenül. Az IF értékek más, a folyóiratok jellemzésére használt mutatókkal együtt évente kerülnek kiszámításra és a Journal Citation Reports-ban (JCR) jelennek meg.” ${ }^{23}$ Számítása: „a folyóirat két egymást követő évfolyamában közölt cikkeinek - a cikkek számával arányosított - átlagos idézettsége a rákövetkező 3. tárgyévben." ${ }^{24}$

\section{ISSN azonositó}

Az ISSN (International Standard Serial Number) az időszaki kiadványok és egyéb folytatódó dokumentumok nemzetközi szabványos azonosítószáma. Numerikus kód, mely a folytatódó dokumentumok egyértelmü azonosítására szolgál. Az ISSN nyolc számjegyből áll, a numerikus kód elemei - a könyveket azonosító ISBN-től eltérően semmiféle jelentést nem hordoznak, csupán azonosító funkciót töltenek be. Az ISSN alkalmazását az ISO 3297 nemzetközi szabvány, illetve annak honosított változata, az MSZ ISO 3297 írja elö. ${ }^{25}$

22 Szluka Péter: Bibliometriai mérőszámok - elmélet és gyakorlat. előadás https://bit.ly/30LMshj

23 Impakt faktor. SZTE Szerzői eszköztár http://bit.ly/38ILze2

24 Sasvári Péter, Nemeslaki András: Tudományos folyóiratok méltányos rangsorolása az MTA Gazdasági és Jogi Osztályában: mit mutatnak az adatok? In: Magyar Tudomány vol. 178. iss. 1.pp. 80-91. 2017. https://bit.ly/3tlOqBi

25 Gazdag Tiborné (összeállította): Országos Széchényi KönyvtárMagyar ISSN Nemzeti Központ: ISSN útmutató https://bit.ly/38ILW8q 


\section{Láthatatlan egyetem}

Olyan értelmiségiekből álló közösség, akik egy adott szakterület képviselöiként informális módon és intézményesült keretek nélkül tartják a kapcsolatot, valamint megosztják egymással a kutatói munkájuk sarkalatos elemeit.

\section{SCImago Journal Rankings}

„Az SJR komplex mutató, amely az idézések számát súlyozza az idéző folyóiratok idézettségével (,presztizsmutató”). Ez a relatív mutató azt fejezi ki, hogy a vizsgált folyóirat az adott szakterületi kategória kiadványainak mekkora hányadát előzi meg SJR tekintetében.

Módszertanilag ez a közlemények minőségi osztályokba (kvartilisokba) sorolásával történik a közlő folyóiratok saját szakterületükön elfoglalt pozíciói, rangjai alapján:

- Q1: Kiváló folyóiratok, amelyek a szakterületi SJR- (méröszámalapú) rangsor felső 25\%-ához tartoznak.

- Q2: Jó folyóiratok, amelyek a szakterületi SJR-rangsor 5075\%-a közé tartoznak.

- Q3: Közepes folyóiratok, amelyek a szakterületi SJR-rangsor 25-50\%-a közé tartoznak.

- Q4: Gyenge folyóiratok, amelyek a szakterületi SJR-rangsor alsó $25 \%$-ához tartoznak.

Egy folyóiratot több szakterületen is jegyezhetnek, és elöfordulhat az, hogy az egyik szakterületen „kiváló” besorolást kap a szóban forgó folyóirat, míg a másik szakterületen csak a „közepes” vagy akár a „gyenge” kategóriába kerül. ${ }^{26}$

\section{Tudománymetria}

A tudománymetria célja számokkal (tudománymetriai mutatókkal) jellemezni a tudományos teljesítményt elsősorban annak hatása, a kapcsolódó közlemények száma és ezek megjelenési helye alapján - azaz a konkrét kutatási tartalom figyelembe vétele nélkül. Ez természetesen nem lehet egzakt, a legtöbb esetben statisztikára, azaz egyfajta átlagolásra épül és erősen szakterületfüggő, ezért érdemes ennek megfelelöen értelmezni. Ugyanakkor a tudománymetriai mutatókat használják kutatók teljesítményének összevetésekor, pá-

26 Sasvári Péter, Nemeslaki András: Tudományos folyóiratok méltányos rangsorolása az MTA Gazdasági és Jogi Osztályában: mit mutatnak az adatok? In: Magyar Tudomány vol. 178. iss. 1. pp. 80-91. 2017. https://bit.ly/3tlOqBi 
lyázatok elbírálásakor, fokozatszerzések, tudományos előrelépések mérlegelésekor is. Ezek mellett a foglalkoztató intézmény teljesítményének megítélésében is nélkülözhetetlenek." ${ }^{27}$

\section{Tudományos kommunikáció}

„A tudományos kommunikálás magában foglalja a kutatási eredmények publikálását, az információhordozókban való áramlását, az információknak mások által való megismerését, befogadását és a tudományos ismeretanyagba való beépülését." ${ }^{28}$

\subsection{Felhasznált irodalom}

1. Schubert András: A folyóirat-kiadás szereplöi a társadalom- és orvostudományokban. In: Orvosi Hetilap vol. 156. iss. 16. pp. 650653. 2015. http://bit.ly/3eELnjK

2. Nancy Fjällbrant: Scholarly Communication - Historical Development and New Possibilities. In: Proceedings of the IATUL Conferences. 1997. Paper 5. http://bit.ly/2Nj4dSd

3. Alice Meadows: Journals Peer Review: Past, Present, Future. In: The Scholarly Kitchen 2017. szept. 14. http://bit.ly/3eF5fmU; Kornis Gyula: Az akadémiák. In: Tudomány és társadalom. A tudomány szociológiája 1. kötet. Budapest: Franklin-Társulat, 1944. pp. 431-440.

4. Ana Maria Ramlho Correia, José Carlos Teixeira: Reforming scholarly publishing and knowledge communication. From the advent of the scholarly journal to the challenges of open access. = A tudományos publikálás és kommunikáció megújulása Tóth Máté (ford.). In: Tudományos és Müszaki Tájékoztatás vol. 53. iss. 10. pp. 471-473. 2006. http://bit.ly/3rRIXlt; Börzsönyi Nóra: Hozzáférhetö tudomány: Az open access és az értéknövelt publikációk világa a könyvtári gyakorlat tükrében. https://bit.ly/2Oyqb43

5. Bikádi Katalin: Trendek a tudományos publikálásban. In: Orvosi könyvtárak: a Magyar Orvosi Könyvtárak Szövetségének hivatalos lapja vol. 11. iss. 2. pp. 11. 2014. http://bit.ly/2OUqki4

6. Sipos Anna Magdolna: A folyóiratkrízisről. A szakfolyóiratok kiadási modelljének változásairól és áremelkedési tendenciáról könyvtáros szemmel. 1. rész. In: Könyvtári Figyelő vol. 63. iss. 1. pp. 26. 2017. https://bit.ly/3qHyHec

27 Tudománymetria. SZTE Doktori Intézet - Doktoranduszoknak - Publikálás, könyvtári információk http://bit.ly/3vqjqSM

28 Bujdosó Ernő: A tudományos publikálás és kommunikálás. In: Bibliometria és tudománymetria. Budapest: Könyvtártudományi és Módszertani Központ Magyar Tudományos Akadémia Könyvtára, 1986. pp. 65. http://bit.ly/3tpVvkx 
7. Sipos Anna Magdolna: A folyóiratkrízisről. A szakfolyóiratok kiadási modelljének változásairól és áremelkedési tendenciáról könyvtáros szemmel. 1. rész. In: Könyvtári Figyelő vol. 63. iss. 1. pp. 11. 2017. https://bit.ly/3qHyHec

8. Bikádi Katalin: Trendek a tudományos publikálásban. In: Orvosi könyvtárak: a Magyar Orvosi Könyvtárak Szövetségének hivatalos lapja vol. 11. iss. 2. pp. 10-11. 2014. http://bit.ly/2OUqki4

9. Tomasz Gábor: Átalakulóban a tudományos folyóiratok kiadási modellje. In: Educatio vol. 22. iss. 3. pp. 354. 2013. https://bit.ly/3lkBjhc

10. Sipos Anna Magdolna: A folyóiratkrízisről. A szakfolyóiratok kiadási modelljének változásairól és áremelkedési tendenciáról könyvtáros szemmel. 1. rész. In: Könyvtári Figyelő vol. 63. iss. 1. pp. 12. 2017., uö. pp. 17. https://bit.ly/3qHyHec

11. Sipos Anna Magdolna: A folyóiratkrízisről. A szakfolyóiratok kiadási modelljének változásairól és áremelkedési tendenciáról könyvtáros szemmel. 1. rész. In: Könyvtári Figyelő vol. 63. iss. 1. pp. 12. 2017., uö. pp. 17. https://bit.ly/3qHyHec

12. Kolozsi Ádám: A kazah kalózlány esete a forrongó tudósokkal. In: index.hu 2016.06.17. http://bit.ly/30GhFTa (2018.06.02.); Tomasz Gábor: Átalakulóban a tudományos folyóiratok kiadási modellje. In: Educatio vol. 22. iss. 3. pp. 355. 2013. https://bit.ly/31kBjhc

13. Varga Máté: A tudomány publikációs válsága (és egy lehetséges kiút). In: sciencemeetup.444.hu 2016. április 4. http://bit.ly/3bMqKA2

14. Bátorfy Attila: 47 millió cikket lopott eddig el, hogy ingyenesen közzétegye öket. In: vs.hu 2016. február 19. http://bit.ly/31sZ1Xr

15. Világok harca - Kutatók vs. Elsevier. In: criticalmass.blog.hu 2012.02.12. http://bit.ly/2Q5yViI

16. Sipos Anna Magdolna: A folyóiratkrízisről. A szakfolyóiratok kiadási modelljének változásairól és áremelkedési tendenciáról könyvtáros szemmel. 1. rész. In: Könyvtári Figyelö vol. 63. iss. 1. pp. 14. 2017. https://bit.ly/3qHyHec

17. Varga Máté: A tudomány publikációs válsága (és egy lehetséges kiút). In: sciencemeetup.444.hu 2016. április 4. https://bit.ly/3bMqKA2

18. Tomasz Gábor: Átalakulóban a tudományos folyóiratok kiadási modellje. In: Educatio vol. 22. iss. 3. pp. 358-359. 2013. https://bit.ly/3lkBjhc

19. Horváth Bence: Fellázadtak a német egyetemek és könyvtárak a szabad tudásért. In: 444.hu 2016. december 22. https://bit.ly/2OV1SgM

20. Bátorfy Attila: 47 millió cikket lopott eddig el, hogy ingyenesen közzétegye öket. In: vs.hu 2016. február 19. https://bit.ly/31sZ1Xr

21. Tomasz Gábor: Átalakulóban a tudományos folyóiratok kiadási modellje. In: Educatio vol. 22. iss. 3. pp. 356.2013. https://bit.ly/3lkBjhc 
22. Szluka Péter: Bibliometriai mérőszámok - elmélet és gyakorlat. előadás https://bit.ly/30LMshj

23. Impakt faktor. SZTE Szerzői eszköztár http://bit.ly/38ILze2

24. Sasvári Péter, Nemeslaki András: Tudományos folyóiratok méltányos rangsorolása az MTA Gazdasági és Jogi Osztályában: mit mutatnak az adatok? In: Magyar Tudomány vol. 178. iss. 1. pp. 80-91. 2017. https://bit.ly/3tlOqBi

25. Gazdag Tiborné (összeállította): Országos Széchényi KönyvtárMagyar ISSN Nemzeti Központ: ISSN útmutató https://bit.ly/38ILW8q

26. Sasvári Péter, Nemeslaki András: Tudományos folyóiratok méltányos rangsorolása az MTA Gazdasági és Jogi Osztályában: mit mutatnak az adatok? In: Magyar Tudomány vol. 178. iss. 1. pp. 80-91. 2017. https://bit.ly/3tlOqBi

27. Tudománymetria. SZTE Doktori Intézet - Doktoranduszoknak Publikálás, könyvtári információk https://bit.ly/3vqjqSM

28. Bujdosó Ernő: A tudományos publikálás és kommunikálás. In: Bibliometria és tudománymetria. Budapest: Könyvtártudományi és Módszertani Központ - Magyar Tudományos Akadémia Könyvtára, 1986. pp. 65. https://bit.ly/3tpVvkx

\section{7. Összefoglalás}

A folyóiratok megjelenése meghatározó jelentőségü volt a mai értelemben vett tudományos publikálás kialakulásában: a szakmai ismeretek és a kutatási eredmények közlésének leggyorsabb és legmegbízhatóbb fóruma lett. Nemzetközi szinten megkönnyítette a tudományos közösségek számára a kommunikációt, valamint biztosította a kutatási eredmények és a szerzői elsőség azonosítását. Nélkülözhetetlen szerepüket elsősorban a természettudományi, müszaki, valamint orvostudományi (STM-science, technology, medical) területeken vívták ki, de a többi tudományterületen is tekintélyt szereztek maguknak. A legtöbb folyóirat a kezdetben magas színvonalú kiadói gondozásnak és a kvantálhatóságuk által hozzájuk rendelt presztízs mutatóknak köszönhetik az egyre növekvő befolyásukat. Az évek során növekvő elvárások az akadémiai szférában, a kiadók agresszív nyomulása a folyóirat-kínálat és az előfizetési árak folyamatos növelésével, továbbá a technikai lehetőségek fejlődése azonban tarthatatlanná tette a 19. században kialakult és évtizedeken át szinte változatlanul létező kiadási modell fenntartását. A lektorált folyóiratokra továbbra is nagy szükség van, azonban a bekerülési ráta, a publikációk hosszú megjelenési ideje és a magas előfizetési díjak nincsenek kedvező hatással a kiadók, és ezáltal a legnívósabb folyóiratok megítélésére sem. 


\section{8. Önellenőrző kérdések}

Sorolja fel a folyóiratkrízis legfontosabb jellemzőit!

A válaszok a „A folyóiratkrízis kialakulásának okai” c. alfejezetben találhatók.

Összegezze néhány mondatban, hogy milyen gyengeségei vannak a hagyományos folyóirat-kiadás modelljének?

A válaszok „A hagyományos kiadási modell buktatói, amik új irányelvek eszméinek a megszületéséhez vezettek" c. alfejezetben találhatók.

Mit jelent a publikációs kényszer?

A szerzőkre nehezedő teljesítménykényszer, ami arra ösztönzi őket, hogy minél többet publikáljanak az egyéni és a munkáltató intézményének kvantálhatósága és presztízs megítélése érdekében.

Mik a hagyományos kiadási modell hátrányai a kutatók számára?

Hozzáférés hiánya, erős hagyományokra és hierarchikus rendszerekre épülő folyamatok, hosszú átfutási idő, zárt kutatói közösségek, a szerzői jogok a kiadóhoz kerülnek.

\subsection{Tesztkérdések}

1. Melyik évszázadban adták ki az első tudományos folyóiratokat?

[ ] 16. század; [•] 17. század; [ ] 18. század; [ ] 19. század

2. Kezdetben milyen intézmények voltak felelösek a folyóirat-kiadásért?

[ ] Az egyetemek;

[ ] Az egyház;

[•] Az akadémiák és tudós társaságok;

[ ] Mindig is a kiadók voltak

3. Melyik évtizedtöl beszélhetünk folyóiratválságról?

[ ] 1940-es évek; [ ] 1950-es évek; [•] 1960-as évek; [ ] 1970-es évek 


\section{AZ OPEN ACCESS MOZGALOM}

\section{Bevezetö gondolatok}

A tananyag válogatott szakirodalom feldolgozásával mutatja be az Open Access Mozgalom törekvéseit, melyek megértésével a hallgató új kontextusba helyezheti a tudományos publikálás egészét. A tananyag feldolgozása lehetőséget teremt arra, hogy a hallgató a kiadó és a felhasználói oldalról egyaránt betekintést nyerjen a mozgalom okozta változásokba. A feldolgozott ismeretanyag más megvilágításba helyezi a tudományos kommunikáció egyes szereplöit, ami arra ösztönözheti a hallgatót, hogy a továbbiakban is nyomon kövesse az Open Access Mozgalom szakirodalmát.

\section{Célok, megszerezhetö kompetenciák}

A tananyag elsajátítása során a hallgató képessé válik arra, hogy felismerje a különbséget a hagyományos és az open access publikálási modellek között. Az új ismeretek fényében tudatosabban fogja megítélni és megszervezni a saját publikálási tevékenységét. A lecke mindenekelőtt a résztvevő kritikai gondolkodásmódját fejleszti.

Szükséges eszközök, források

Jól működő asztali vagy hordozható számítógép és internetkapcsolat.

Feldolgozási idö

- 90 perc

Témakörök

- Bevezetés

- Az Open Access Mozgalom célja

- Az Open Access Mozgalom úttöröi és fontosabb állomásai

- Fogalommagyarázatok

- Az Open Access Mozgalom hatásai a publikálás világára: a tudományos kommunikáció forradalma

- A lecke ismeretlen fogalmainak magyarázata 


\section{Irodalmak}

- Berlini Nyilatkozat a tudomány nyílt eléréséröl https://bit.ly/38Fqotf

- Bethesda Statement on Open Access Publishing https://bit.ly/3bNZ261

- Bánhegyi Zsolt: Nyílt Hozzáférés Kezdeményezés (Open Access Initiative) - Kitekintés és körkép. In: Tudományos és Müszaki Tájékoztatás vol. 50. iss. 6-7. pp. 236-249. 2003. http://bit.ly/3eFSt7C

- Bátorfy Attila: 47 millió cikket lopott eddig el, hogy ingyenesen közzétegye öket. In: vs.hu 2016. február 19. https://bit.ly/31sZIXr

- Bilicsi Erika, Dér Ádám, Lencsés Ákos: Az Open Access támogatásának közép-európai gyakorlata. In: Könyv, könyvtár, könyvtáros vol. 25. iss. 2. pp. 20-28. 2016. https://bit.ly/3cqaKTq

- Bo-Christer Björk: Open access to scientific articles: a review of benefits and challanged. In: Internal and Emergency Medicine vol. 12. iss. 2. pp. 247-253. 2017. https://bit.ly/2PWpFgC

- Bo-Christer Björk: The open access movement at a crossroads - are the big publishers and academic social media taking over? In: Learned Publishing vol. 29. iss. 2. pp. 131-134. https://bit.ly/30GYRmM

- Budapesti felhívás a szabad hozzáférés érdekében. https://bit.ly/3qNODMa

- Börzsönyi Nóra: Hozzáférhető tudomány. Az open access és az értéknövelt publikációk világa a könyvtári gyakorlat tükrében. Az év fiatal könyvtárosa-díj elnyerésére benyújtott pályamunka. 2015. https://bit.ly/2Oyqb43

- FÁK: Merész német bojkott a helyzetével visszaélő kiadó ellen. In: Index 2016.12.17. http://bit.ly/3qPxiCg

- Holl András: A nyílt hozzáférés nemzetközi és hazai áttekintése. In: Könyv és nevelés vol. 15. iss. 2. pp. 23-28. 2013. https://bit.ly/3tiNRbu

- Holl András: Beszéljünk nyíltan a nyílt hozzáférésröl!: Gondolatok Kovács Kármen A nyílt hozzáférésủ (open access) publikálás néhány bizonytalan következménye címü cikke nyomán. In: Magyar Tudomány vol. 178. iss. 2. pp. 224-227. 2017. https://bit.ly/3bN0CFm

- Holl András, Bilicsi Erika: Az Open Access és a sárgaköves út. In: Tudományos és Müszaki Tájékoztatás vol. 63. iss. 9. pp. 340-343. 2016. http://bit.ly/2Q5Djyd

- Holly Else: Europe's open-access drive escalates as university stand-offs spread. In: Nature 2018. május 17. https://go.nature.com/3qPFWka

- Horváth Bence: Fellázadtak a német egyetemek és könyvtárak a szabad tudásért. In: 444.hu 2016. december 22. https://bit.ly/2OV1SgM

- Horváth Bence: Fél év alatt Budapestről 70 ezren töltöttek le tanulmányokat a legnagyobb tudományos kalózoldalról. In: 444.hu 2016. április 30. http://bit.ly/3bN1AkY

- Karácsony Gyöngyi: A Debreceni Egyetem elektronikus archívuma: a nyílt hozzáférés lehetöségei. In: Tudományos és Müszaki Tájékoztatás vol. 54. iss. 8. pp. 343-351. 2007. http://bit.ly/3qPzGsI 
- Karen Albert: Open access: implications for scholarly publishing and medical libraries. In: Journal of Medical Library Association vol. 94. iss. 3. pp. 253-262. 2006. https://bit.ly/3rQBW4f

- Koltay Tibor, Tóth Erika: A tudományos publikációkhoz való szabad hozzáférés irodalma Magyarországon. In: Tudományos és Müszaki Tájékoztatás vol. 53. iss. 3. pp. 128-132. http://bit.ly/3bNGqTZ

- Kolozsi Ádám: A kazah kalózlány esete a forrongó tudósokkal. In: index.hu 2016.06.17. https://bit.ly/30GhFTa

- Kovács Kármen: A nyílt hozzáférésü (open access) publikálás néhány bizonytalan következménye. In: Magyar Tudomány vol. 178. iss. 1. 71-79. pp. 2017. https://bit.ly/30MhDcl

- Kristin Yiotis: The Open Access Initiative: A new paradigm for scholarly communications $=$ A nyílt hozzáférés kezdeményezés: a tudományos kommunikáció új paradigmája/ (ford.) Bánhegyi Zsolt. In: Tudományos és Müszaki Tájékoztatás vol. 53. iss. 3. pp. 141-142. 2006. http://bit.ly/3bPxux2

- LICA: A tudósok is kénytelenek kalózkodni. In: index.hu 2016.02.15. http://bit.ly/3bNH43B

- Melissa R. Hagemann: Five Years on - The Impact of the Budapest Open Access Initiative. In: Proceedings ELPUB2007 Conference on Electronic Publishing - Vienna, Austria - June 2007 pp. 153-160. 2007. https://bit.ly/2Q6upR5

- Stevan Harnad: The implementation of the Berlin Declaration on Open Access. Report on the Berlin 3 Meeting Held 28 February - 1 March 2005, Southampton, UK. = A szabad hozzáférésről szóló Berlini Nyilatkozat megvalósitása/ (ford.) Koltay Tibor. In: Tudományos és Müszaki Tájékoztatás vol. 52. iss. 9. pp. 430-433. 2005. http://bit.ly/3toXZzk

- Varga Máté: A tudomány publikációs válsága (és egy lehetséges kiút). In: sciencemeetup.444.hu 2016. április 4. https://bit.ly/3bMqKA2

- Világok harca - Kutatók vs. Elsevier. In: criticalmass.blog.hu 2012.02.12. https://bit.ly/2Q5yViI

- Xianwen Wang, Chen Li, Wenli Mao, Zhichao Fang: The open access advantage considering citation, article usage and social media attention. In: Scientometrics vol. 103. iss. 2 . pp. 555-564. 2015. https://bit.ly/30NRNog

\subsection{Bevezetés}

Az előző leckéből egyértelműen kiderült, hogy a hagyományos folyóirat-kiadás modelljének egyes elemei reformálásra szorultak. A lehetőségek széles tárházát biztosító internet egyre komolyabban befolyásolta a szerzők és a kiadók publikálási tevékenységét. Ezeket a potenciálokat felismerve és megragadva kezdte el a tudományos közösség megfogalmazni a változás iránti igényeit. Az Open Access Mozgalom 
meglehetősen összetett néhány mondatban nehezen definiálható témakör, ugyanakkor nagyon fontos része a tudományos kommunikáció paradigmaváltásának. Olyan eszmeiséget követ, ami egészen új alapokra helyezi a kutatók közötti együttmüködést és a publikációk közlését.

\subsection{Az Open Access Mozgalom célja}

Az Open Access Initiative (OAI) vagyis a Nyílt Hozzáférés Kezdeményezés kimondja, hogy az internetnek köszönhetően nincs technikai akadálya annak, hogy a tudományos ismereteket korlátozás nélkül szabadon elérhetővé tegyék. Ez alapvetően megváltoztatja a tudományos közlések terjesztésének gyakorlatát, ami megköveteli új publikálási modellek létrejöttét.

További céljai közt szerepel a kutatási eredmények „közös vagyonként" történő kezelése. A tudás megosztásával az esélyegyenlöség megteremtése és a tudományos diskurzusok felélénkítése, ezáltal a tudomány gyorsabb fejlődésének elérése a végcél.

Az idealistának nevezhető alapelvek megfogalmazása mögött néhány „open access élharcosnak” természetesen az sem kerülte el a figyelmét, hogy az új publikálási modellek változást idézhetnek elö a folyóirat-kiadásban és megszorongathatják a monopolhelyzetben lévő kiadókat.

„Az OA a tudás demokratizálását jelenti, és a tudás terjesztésének egy társadalmilag felelős útját jelöli ki. Ugyanazt a tudást és információt teszi elérhetővé a gazdag, fejlett országok tudósai, a fejlődő világ, valamint a harmadik világ kutatói számára egyaránt. Az OAI és a nyílt hozzáférésủ archívumok léte annak a világszerte meglévő igénynek a bizonyítéka, hogy méltányos, igazságos és demokratikus legyen az információforrások elosztása/terjesztése. S akik adójukkal a kutatást támogatják, jussanak hozzá az előnyeihez ingyen, további költségek fizetése nélkül."

1 Kristin Yiotis: The Open Access Initiative: A new paradigm for scholarly communications = A nyílt hozzáférés kezdeményezés: a tudományos kommunikáció új paradigmája (ford.) Bánhegyi Zsolt. In: Tudományos és Müszaki Tájékoztatás vol. 53.iss. 3.pp. 141-142. 2006. http://bit.ly/3bPxux2 


\subsection{Az Open Access Mozgalom híres úttöröi és fontosabb állomásai}

\section{Paul Ginsparg, fizikus}

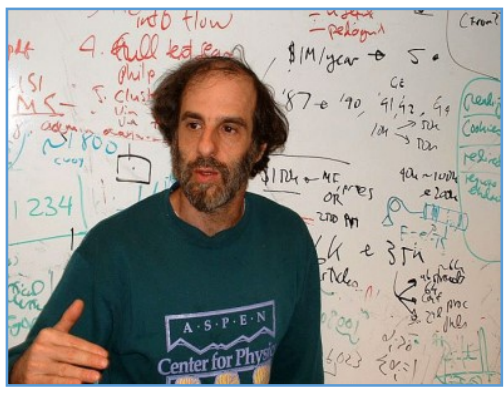

1. kép-Paul Ginsparg

A legtöbben Paul Ginsparget (1. kép) emlegetik az open access mozgalom atyjának. Ginsparg és szerző társai körében már az 1980-as években bevett gyakorlat volt a publikálásra szánt kéziratok megosztása. Eleinte emailben továbbították egymásnak a tudományos eredmények közlésre szánt szövegeit. A könnyebb tárolás, elérhetőség, valamint visszakereshetöség érdekében 1991-ben a Los Alamos National Laboratory falai között Ginsparg létrehozta az akkor még xxx-re (xxx.lanl.gov) keresztelt archívumot vagy, ahogy ma az open acces szakirodalom hívja: repozitóriumot. 2001-ben Ginsparg a Cornell Egyetem munkatársa lett és „tovább vitte” magával a ma már jól ismert, arXiv-re keresztelt preprint-szervert (arXiv.org). Az arXiv-ra kezdetben fizikai, később csillagászati, matematikai, számítástechnikai, biológiai, pénzügyi és statisztikai témájú publikációk lektorálás nélküli változatai kerültek fel. Tudományos lektorálási munkát ugyan nem végeznek az oldal üzemeltetői, de moderátorként igyekeznek kiszürni az oda nem illö, nem tudományos közleményeket. A repozitóriumban egyaránt helyet kapnak azok a publikációk, amelyek a feltöltést követően lektorálva is megjelentek neves szaklapokban, és azok a kéziratok is, melyek sosem kerültek kiadói gondozásba. ${ }^{2}$

\section{Harold E. Varmus, sejtbiológus, virológus (2. kép)}

Nevéhez füződik az orvosbiológia és az élettudományok területén ismert PubMed Central (PMC) repozitórium és a Public Library of Science (PloS) kiadó létrejötte. Ö kezdeményezte azt is, hogy kötelező legyen a National Institute of Health $(\mathrm{NIH})$ által támogatott kutatásokat a PubMed Central-on nyílt hozzáférésủvé tenni. A PMC 018.

2 arXiv.org. In: konyv.guru http://bit.ly/2Q86pNp; Holl András: A nyílt hozzáférés nemzetközi és hazai áttekintése. In: Könyv és nevelés vol. 15. iss. 2. pp. 2328. 2013. https://bit.ly/3tiNRbu; Bánhegyi Zsolt: Nyílt Hozzáférés Kezdeményezés (Open Access Initiative) - Kitekintés és körkép. In: Tudományos és Müszaki Tájékoztatás vol. 50. iss. 6-7. pp. 236-249. 2003. http://bit.ly/3tm4bs5 


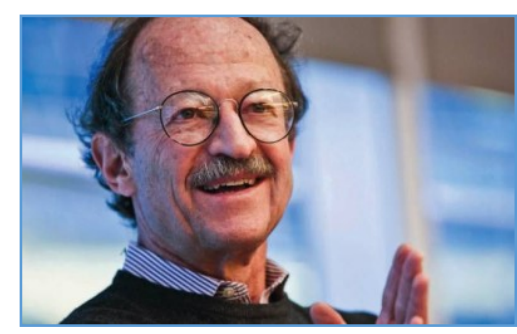

májusi adatai szerint mintegy 4,9 millió cikk érhető el teljes szöveggel szabadon. A PloS kiadó pedig az egyik legismertebb és legsikeresebb open access kiadó. ${ }^{3}$

\section{2. kép - Harold E. Varmus}

Az Amerikai Egyesült Államokban 2009 óta törvény szabályozza, hogy az U. S. National Institute of Health által finanszírozott kutatások eredményeként született publikációkat a megjelenésüket követően elérhetővé kell tenni a PubMed Central-ban. ${ }^{4}$

\section{Stevan Harnad, a kognitív tudományok professzora (3. kép)}

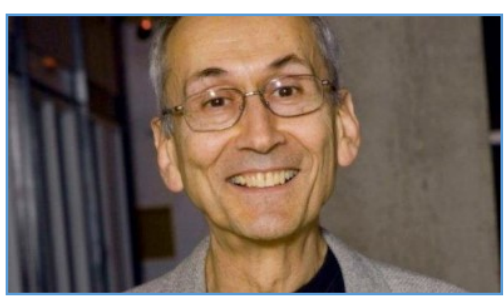

3. kép - Stevan Harnad

Alapítója és főszerkesztője volt az 1990-2002 között müködő Psycholoqy open access folyóiratnak. 1997ben hozta létre a kognitív tudományok repozitóriumát, a Cognitive Sciences Eprints Archive-ot, amit Cogprints-ként lehet megtalálni a világhálón. Az önarchiválás támogatásának egyik legnagyobb élharcosa volt. Véleménye szerint minden lektorált tudományos folyóiratcikk teljes szövegéhez állandó és ingyenes hozzáférést kell biztosítani. Harnad azt is szorgalmazta, hogy a szerző a kiadóhoz való jogátruházás helyett megtarthassa a szerzői jogot. Törekvéseinek megítélése szélsőséges, egyesek szerint ezzel csak az volt a célja, hogy a monopolhelyzetben lévő kiadók folyóirataiba minél kevesebben publikáljanak. ${ }^{5}$

3 Holl András: A nyílt hozzáférés nemzetközi és hazai áttekintése. In: Könyv és nevelés vol. 15. iss. 2. pp. 23-28. 2013. https://bit.ly/3tiNRbu

4 Bajomi Bálint: Hagyományos versus Open Access publikálás. In: Ökológiai Blog - Az MTA Ökológiai Kutatóközpont blogja http://bit.ly/2Q5SO9n

5 Kristin Yiotis: The Open Access Initiative: A new paradigm for scholarly communications = A nyílt hozzáférés kezdeményezés: a tudományos kommunikáció új paradigmája/ (ford.) Bánhegyi Zsolt. In: Tudományos és Müszaki Tájékoztatás vol. 53. iss. 3.pp. 141-142. 2006. http://bit.ly/3bPxux2; Koltay Tibor, Tóth Erika: A tudományos publikációkhoz való szabad hozzáférés irodalma Magyarországon. In: Tudományos és Müszaki Tájékoztatás vol. 53. iss. 3. pp. 128-132. 2006. http://bit.ly/3bNGqTZ 


\section{A Santa Fe Konvenció}

Az Open Archives Initiative, melynek alapító tagjai között volt Paul Ginsparg és kollégái Rick Luce, valamint Herbert Van de Sompel 1999-ben Santa Fe-ben szervezte meg azt a két napos találkozót, melynek keretében a résztvevők egyhangúan elfogadták az interoperabilitás elvét és véglegesítették az OAI Protocol for Metadata Harvesting, OAI-PMH metaadatgyüjtő modellt. A résztvevők mindegyike olyan intézményt képviselt, ami az arXiv-hoz hasonló preprintszervert üzemeltetett, tervezte bevezetését, vagy szolgáltatásuk nyílt hozzáférésủ archívumokra épült. ${ }^{6}$

\section{A Budapest Open Access Initiative (BOAI)}

Az Open Society Institute támogatásával 2001-ben, Budapesten szervezték meg azt a konferenciát, amely egyesítette az open access kezdeményezéseket és megfogalmazta az Open Access Mozgalom alapelveit. A 2002-ben kiadott manifesztum magyar nyelven is elérhető. Ez a dokumentum valójában megfogalmazta, hogy mit is jelent a teljes szövegü dokumentumok nyílt hozzáférése, valamint javaslatot tett a nyílt közzététel megvalósítási lehetőségeire is.

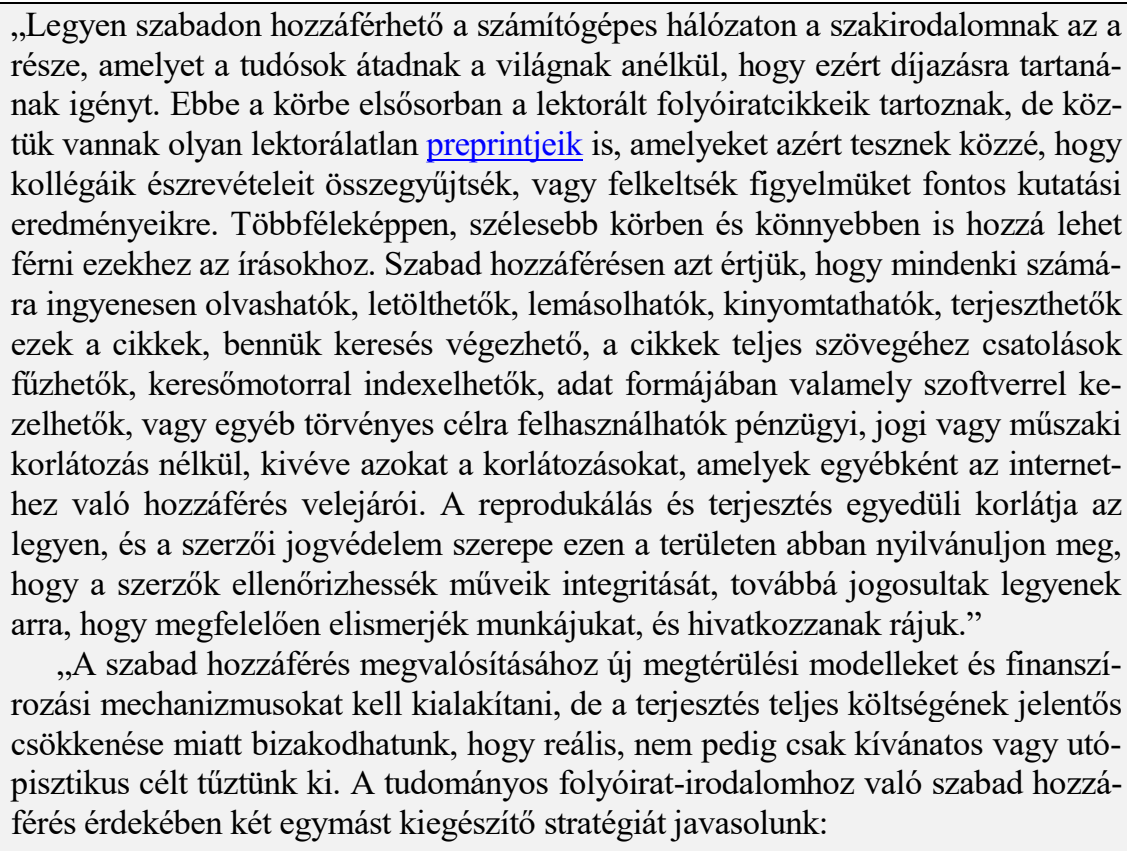
része, amelyet a tudósok átadnak a világnak anélkül, hogy ezért díjazásra tartanának igényt. Ebbe a körbe elsősorban a lektorált folyóiratcikkeik tartoznak, de köztük vannak olyan lektorálatlan preprintjeik is, amelyeket azért tesznek közzé, hogy kollégáik észrevételeit összegyüjtsék, vagy felkeltsék figyelmüket fontos kutatási eredményeikre. Többféleképpen, szélesebb körben és könnyebben is hozzá lehet férni ezekhez az írásokhoz. Szabad hozzáférésen azt értjük, hogy mindenki számára ingyenesen olvashatók, letölthetők, lemásolhatók, kinyomtathatók, terjeszthetők ezek a cikkek, bennük keresés végezhető, a cikkek teljes szövegéhez csatolások füzhetők, keresőmotorral indexelhetők, adat formájában valamely szoftverrel kezelhetők, vagy egyéb törvényes célra felhasználhatók pénzügyi, jogi vagy müszaki korlátozás nélkül, kivéve azokat a korlátozásokat, amelyek egyébként az internethez való hozzáférés velejárói. A reprodukálás és terjesztés egyedüli korlátja az legyen, és a szerzői jogvédelem szerepe ezen a területen abban nyilvánuljon meg, hogy a szerzők ellenőrizhessék műveik integritását, továbbá jogosultak legyenek arra, hogy megfelelően elismerjék munkájukat, és hivatkozzanak rájuk.'

„A szabad hozzáférés megvalósításához új megtérülési modelleket és finanszírozási mechanizmusokat kell kialakítani, de a terjesztés teljes költségének jelentős csökkenése miatt bizakodhatunk, hogy reális, nem pedig csak kívánatos vagy utópisztikus célt tüztünk ki. A tudományos folyóirat-irodalomhoz való szabad hozzáférés érdekében két egymást kiegészítő stratégiát javasolunk:

6 the Santa Fe Convention for the Open Archives Initiative http://bit.ly/30NZH0U 
I. Saját archiválás: A tudósoknak elöször is eszközökre és támogatásra van szükségük lektorált folyóiratcikkeik nyílt elektronikus archívumokban való elhelyezéséhez; ezt szokták saját archiválásnak nevezni. Ha ezek az archívumok megfelelnek a Nyílt Archívumok Kezdeményezés (Open Archives Initiative) szabványainak, a keresőmotorok és más eszközök közösen tudják lekérdezni őket. A használóknak nem is kell tudniuk, milyen archívumok léteznek, és hol találhatók, hogy megtalálhassák és használják a tartalmukat.

II. Alternatív folyóiratok: A tudósoknak emellett eszközökre van szükségük olyan új generációs, a megszokottól eltérő folyóiratok indításához, amelyek elkötelezettek a szabad hozzáférés mellett, illetve ahhoz, hogy segítsék a meglévő folyóiratok áttérését a szabad hozzáférésre. Mivel a folyóiratcikkeket a lehető legszélesebb körben kívánjuk terjeszteni, ezek az új folyóiratok már nem támaszkodnak majd a szerzői jog elöírásaira annak érdekében, hogy korlátozzák az általuk publikált dokumentumok elérhetőségét és használatát. Ehelyett a szerzői jogot és más eszközöket arra használják majd, hogy tartósan szabad hozzáférést biztosítsanak az általuk publikált cikkek mindegyikéhez. Mivel a magas ár is akadálya lehet a hozzáférésnek, ezek az új folyóiratok nem számítanak fel előfizetési vagy hozzáférési dijat, hanem más módszerekkel fedezik kiadásaikat. Erre a célra sokféle egyéb pénzügyi forrás áll rendelkezésre, köztük kutatást támogató alapítványok és kormányok, a kutatókat foglalkoztató egyetemek és laboratóriumok, az egyes tudományágakban vagy intézményekben müködő alapítványok, a szabad hozzáférés eszméjének támogatói, a szövegek mellett megjelenő hirdetések stb. profitja, továbbá azok a pénzösszegek, amelyek a korábbi, előfizethető vagy az elérésért díjat kérő folyóiratok megszünésével felszabadulnak, vagy akár maguknak a kutatóknak a hozzájárulásai. E megoldások egyikét sem kell előnyben részesíteni a többivel szemben a tudományágak vagy országok mindegyikében, és nincs szükség arra sem, hogy most már ne keressünk újabb, kreatív megoldási lehetőségeket.

Az a célunk, hogy a lektorált folyóirat-irodalom szabadon hozzáférhető legyen. Ezt a célt a saját archiválással (I.) és a szabadon hozzáférhető alternatív folyóiratok új generációjával (II.) érhetjük el." ${ }^{, 7}$

\section{A Bethesda Nyilatkozat}

2003-ban a Howard Hughes Egészségügyi Intézet központjában, Maryland-ben újabb találkozót szerveztek, melynek eredményeképpen a résztvevők megfogalmazták és aláírták a Bethesda Nyilatkozatot, melynek elsődleges célja az volt, hogy diskurzust eredményezzen az orvosbiológiai kutatásokkal foglalkozó közösségen belül arról, hogy hogyan lehet a lehető leggyorsabban szabad hozzáférést biztosítani a szakterületük elsődleges tudományos eredményeihez. Megállapodtanak továbbá azokban a lényeges és konkrét lépésekben, melyeket a résztvevő intézmények mindegyike megtehet, hogy segítse az átállást a nyílt hozzáférésü publikációkra.

7 Budapesti felhívás a szabad hozzáférés érdekében http://bit.ly/3tkdGrz 
A nyilatkozat definiálja a nyílt hozzáférésü közlemények két fontos követelményét, melynek első pontja a publikációk szabad megosztására, második pontja a repozitóriumi közzétételre helyezi a hangsúlyt. A dokumentum további részében a finanszírozó intézmények, a könyvtárak és kiadók, valamint a tudományos közösségek gyüjtik össze az open access megvalósulásához szükséges teendők listáját. ${ }^{8}$

\section{A Berlini Nyilatkozat}

Nem sokkal a Bethesda Nyilatkozat után, ugyancsak 2003-ban került sor a Berlini Nyilatkozat megfogalmazásra és elfogadásra. A kiáltvány aláírásával több száz kutatási intézmény és egyetem csatlakozott az open access mozgalomhoz. Tartalmát tekintve a manifesztum nem sokban különbözik elödeitől. Bevezetőjében hivatkoznak a korábbi nyilatkozatokra (A Budapesti Nyílt Hozzáférés Kezdeményezés [Budapest Open Access Initiative], a Bethesda Nyilatkozat a Nyílt Hozzáférésű Publikálásról [Bethesda Statement on Open Access Publishing]). A célok természetesen számos pontban összhangban voltak és megegyeztek az előző dokumentumokban megfogalmazottakkal, vagyis, hogy az aláírók kötelességüknek érzik az információk, a tudományos eredmények és a kutatáshoz kapcsolódó dokumentumok széles körben történő terjesztését, melynek eszközeként egyértelmüen az internetet említik. A nyílt hozzáférésủ publikációknak ugyanaz a két feltétele olvasható benne, mint a Bethesda Nyilatkozatban. Míg a budapesti manifesztumban többnyire a célok és alapelvek szerepelnek, a bethesdaiban az aláíró intézmények igyekeztek röviden állást foglalni a rájuk váró feladatokról, addig a Berlini Nyilatkozatban inkább a mozgalom támogatásához csatlakotnak az aláírók.

„Az open access publikálás fogalma

A nyílt elérhetőség valójában akkor valósítható meg, ha a tudományos ismeretek minden egyes szerzője és a kulturális örökség minden egyes birtokosa ennek aktív elkötelezettje. A nyílt hozzáférésű publikációk körébe eredeti tudományos kutatási eredmények, nyers adatok, metaadatok, forrásanyagok, festészeti és grafikai anyagok digitális ábrázolásai, multimédiás tudományos anyagok tartoznak.",9

8 Bethesda Statement on Open Access Publishing https://bit.ly/3bNZ261

9 Berlini Nyilatkozat a tudomány nyílt eléréséröl https://bit.ly/38Fqotf 
Az Európai Unió 2008 óta támogatja a nyílt hozzáférést. A 2011-ben publikált tudományos cikkek 50\%-a elérhetővé vált OA formában is. Az EU döntése alapján a cél, hogy a közpénzből finanszírozott kutatások eredményeiből született publikációkat 2020-tól mindenki számára ingyenesen elérhetővé kell tenni. Az Open Access Mozgalom mellett történő elköteleződés bizonyítékaként érdemes megismernünk két fontosabb és még ma is tartó projektet. ${ }^{10}$

\section{OpenAIRE}

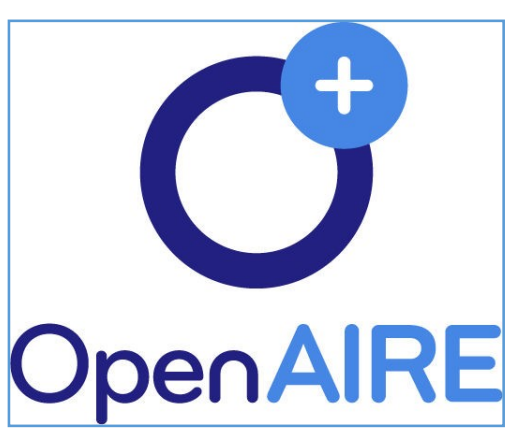

1. ábra-OpenAIRE

„Az OpenAIRE (1. ábra) (Open Access Infrastructure for Research in Europe) az európai országok összefogásában létrejött Open Access projekt. A projekt fö célja az Open Access program támogatása, amit az Európai Bizottság 2008 augusztusában indított. Ez a három éves ambiciózus kezdeményezés 27 európai országból 38 partner intézmény közreműködésével indult és a 7. keretprogram által finanszírozott projekt. A résztvevő kutatók vállalják, hogy a meghatározott kutatási témákban (Egészségügy, Energia, Információs és kommunikációs technológiák, Környezetvédelem, Társadalomgazdaságtan és humán tudományok, Kutatási infrastruktúrák, Tudomány a társadalomban) publikációikat nyílt hozzáférésü intézményi repozitóriumokba töltik fel, és ehhez az OpenAIRE projekt biztosítja az alapfeltételeket és Helpdesk szolgáltatást, továbbá vállalja egy európai repozitóriumi hálózat e-infrastruktúrájának kiépítését."11

10 Börzsönyi Nóra: Hozzáférhető tudomány: Az open access és az értéknövelt publikációk világa a könyvtári gyakorlat tükrében. https://bit.ly/2Oyqb43; Kovács Kármen: A nyílt hozzáférés (open access) publikálás néhány bizonytalan következménye. In: Magyar Tudomány vol. 178. iss. 1. pp. 71-79. 2017. https://bit.ly/38CY3Uk

11 Open Access - tudástár. Nemzeti Kutatási, Fejlesztési és Innovációs Hivatal https://bit.ly/2OysSmj 


\section{P7 GOLD OA PILOT}

„Az Európai Tanács finanszírozásában és az OpenAIRE program keretében útjára indult a Gold OA Pilot (arany utas nyílt hozzáférésü publikálást támogató kezdeményezés), amely lehetőséget biztosít a lezárult FP7 projektek számára, hogy nyílt hozzáféréssel publikálják tudományos eredményeiket OA folyóiratokban. A kezdeményezés az OpenAIRE2020 projekt kontextusában került kidolgozásra, így az OpenAIRE által kialakított európai infrastruktúra és támogatási rendszer keretében lesz lebonyolítva. A pilot projektnek kettős célja van: (1) támogatja az FP7-es keretprogramban finanszírozott kutatások eredményeinek nyílt hozzáférésủ publikálását, (2) európai szinten felmérést készít a tudományos publikálási szokásokról.”12

\section{Magyarország csatlakozása az Open Access Mozgalomhoz}

Az OTKA (Országos Tudományos Kutatási Alapprogramok) 2008-ban írta alá a 2018-ban világszerte közel 500 tagot számláló Berlini Nyilatkozatot, mellyel elkötelezte magát a nyílt hozzáférés mozgalma mellett.

A Magyar Tudományos Akadémia (MTA) 27/2012. (IX.24.) számú hivatalos elnöki határozata elöírja, hogy 2013. január 1-jétől az Akadémia kutatói által közétett publikációkat elektronikus formában szabadon elérhetővé kell tenni.

„A Hungarian Open Repositories (HUNOR) konzorciumot a magyar felsőoktatási intézmények és az MTA Könyvtára hozta létre a nyílt hozzáférés $(\mathrm{OA})$ hazai gyakorlatának kialakítása céljából. A HUNOR tagjai a magyar tudomány hazai és nemzetközi elismerésének javítását a tudományos eredmények hatékony disszeminációjával kívánják elérni, nevezetesen nyílt elérésü repozitóriumok országos infrastrukturális hálózatának kialakításával, módszertani központ létrehozásával, a külföldi know-how és nemzetközi szabványok hazai alkalmazásával, a tudományos kommunikáció komplementer csatornáinak meghonosításával, nemzetközi kapcsolatrendszer kiépítésével."13

\footnotetext{
12 Open Access - tudástár. Nemzeti Kutatási, Fejlesztési és Innovációs Hivatal https://bit.ly/2OysSmj

13 Uott.
} 


\subsection{Fogalom magyarázatok}

A történeti háttér bemutatását követően érdemes összegeznünk néhány eddig elhangzott és folyamatosan használt fogalom jelentését.

\section{Open access}

Az open access vagyis nyílt hozzáférés több jelentéstartalommal bír. Egyrészt a tudományos publikálás világában minden olyan mozgalom, kezdeményezés vagy intézmény nevében és/vagy eszmeiségében fellelhető kifejezés, ami a tudományos eredmények szabad, térítésmentes, állandó hozzáférésének a biztosítására utal a világon élő összes ember számára.

Másrészt jelenti azokat a dokumentumokat, melyek ennek az irányelvnek és a Creative Commons által meghatározott licencek mentén az internetről szabadon letölthetők, kinyomtathatók, szerkeszthetők, továbbíthatók, keresés végezhető bennük, magyarázatok és jegyzetek füzhetők hozzájuk, nem rendelkeznek szigorú terjedelmi korlátokkal, kereső motorokkal indexelhetők, kereszthivatkozások találhatóak bennük és repozitóriumba feltölthetök.

\section{Repozitórium}

„A repozitórium egyetemeken és kutatási intézményekben müködő dokumentumszerver, amely tudományos anyagok archiválására és világszerte díjmentes hozzáférhetővé tételére szolgál. Intézményi és diszciplináris repozitóriumokat különböztetünk meg.

Intézményi repozitóriumnak azokat a dokumentumszervereket nevezzük, amelyeket intézmények (föleg egyetemi könyvtárak vagy kutatási szervezetek) üzemeltetnek, és tagjaik számára lehetővé teszik a digitális publikálást és az önarchiválást.

A diszciplináris, másnéven tudományterületi repozitóriumok túllépnek az intézményi kereteken, és a kutatók számára tematikailag gyüjtik össze, bocsátják rendelkezésre a publikációkat és az archiválás lehetőségét.

Az intézményi és a diszciplináris repozitóriumokban rendszerint dijmentes a tudományos publikációkhoz való hozzáférés a felhasználók számára, illetve a tudományos publikálás a szerzők számára.

Aki ma tudományos információt keres, annak nem kell a különböző repozitóriumokat egyesével átkutatnia. Az OAI kezdeményezés keretében létrehozott OAI-PMH (Open Archives Initiative - Protocol for Metadata Harvesting), ami egy XML-protokoll, a metaadatok le- 
kérdezésével és átvitelével lehetővé teszi a repozitóriumok együttes kereshetőségét."14

A repozitóriumokat tartalmuk szerint is megkülönböztethetjük. Léteznek például adatrepozitóriumok, ahol a kutatási adatokat, valamint a kutatáshoz tartozó bővítményeket és függelékeket nyílt vagy korlátozott hozzáféréssel lehet tárolni. Általában az egyetem intézményi repozitóriumainak részét képzik a szakdolgozati, a disszertációs, valamint a belső dokumentumok őrzését biztosító modulok.

\subsection{Az Open Access Mozgalom hatásai a publikálás világára: a tudományos kommunikáció forradalma}

Az Open Access Mozgalom irányelvei tulajdonképpen reakciók voltak a hagyományos publikálási modell negatív komponenseire. Sokan, sokféleképpen igyekeztek megragadni a lényegét, de végül a közös nevező mindig a tudományos eredményekhez történő szabad hozzáférés igényét jelentette. A megvalósítására törekvő kezdeti szárnypróbálgatások következtében bekövetkeztek és jelenleg is zajlanak olyan változások, melyek némelyike egyelőre beláthatatlan következményekkel befolyásolhatja a tudományos kommunikációt. Ebben a fejezetben a teljesség igénye nélkül gyüjtöttük össze, azokat a folyamatokat, melyeket közvetlenül vagy közvetett módon az Open Access Mozgalom hatásaiként is felismerhetünk.

\section{A publikálás módja}

A folyóiratokban történő publikálás hagyományos útja, mikor a publikálásra szánt kéziratot a szerző eljuttatja a választott folyóirat szerkesztőbizottságához, akik a befogadást és a szakmai lektorálást követően a folyóirat valamelyik évfolyamának, valamelyik számában megjelentetik azt. A szerző(k)nek a cikk megjelentetésért nem kell fizetnie, helyettük az olvasó közvetlenül vagy közvetett módon (általában könyvtári szolgáltatásként), előfizetés vagy az adott folyóiratszám/cikk megvásárlása útján elektronikusan vagy nyomtatott formában fér hozzá a teljes szövegü tartalomhoz.

A folyóiratokban történő open access publikálás a hagyományos modell ellentéte. A publikáció kiadásával járó költségeket nem a felhasználónak kell finanszíroznia, hanem a szerzőnek. A szerző fizeti ki a lektorálást és a cikk kiadási költségeit. A felhasználó (aki lehet a

14 Repozitóriumok. Openscience.hu https://bit.ly/2OVQWzv 
folyóirat olvasója vagy szolgáltatója, például a könyvtár) a cikk megjelenését követően szabadon (vagyis: ingyen) online, elektronikus vagy nyomtatott formában bárhol olvashatja azt.

Article Processing Charge-nak, magyarul közzétételi dijjnak vagy publikálási
költségnek nevezik azt az összeget, amit a szerzök fizetnek a közlemény megje-
lentetésért. Kiadónként és folyóiratonként eltérö árazásról beszélhetünk. A szer-
zöknek érthetö módon nem áll rendelkezésükre annyi egyéni forrás, hogy önálló-
an fizessék ki ezeket a díjakat. Éppen ezért többnyire az egyetemek, kutatóintéze-
tek költségvetésébe építik be az open access költségeket. Az egyetemek gyakran
open access publikálási alapot különítenek el, melyekkel az intézmény és a ki-
adók között kötött szerzödés keretében segítik a szerzök open access úton történő
publikálását. A szerződések koordinálói általában az egyetemi könyvtárak, akik a
kiadókkal történö kapcsolattartásért, a szerzők informálásáért felelösek. Egyre
több pályázat keretében is számolnak el open access publikációs költségeket, s
léteznek kifejezett támogatói intézmények, mint a Wellcome Trust, amelyek te-
vékenységi körükbe építették az open access cikktámogatást.
Vannak olyan felsöoktatási intézmények, melyek úgy döntöttek, hogy saját
maguk hoznak létre open access kiadót, ezáltal biztosítva oktatóiknak az open
access módon történő publikálást.
Az open access folyóiratokban megjelent cikkek esetében a szerzői jog nem
kerül a kiadóhoz. A kiadóknak csak a publikációkra vonatkozó közlési és felhasz-
nálási engedélye lesz. A közleményeket Creative Commons licensszel látják el,
ami meghatározza, hogy az olvasó milyen további módon használhatja a cikkeket.
„A nyílt hozzáféréssel közölt publikációk felhasználását a szerzö(k) és a ki-
adó közötti megállapodás rögzíti (,,license policy”). Az egyik leggyakoribb ilyen
licensz-csomag a Creative Commons (CC) által használt „CC BY”, melyet pél-
dául az Elsevier is használ. A licenszek megszabják az adott közlemény további
felhasználásának lehetőségeit.”ls

Az open access díjfizetős publikálásnak eltérő módjai lehetnek.

Platinum open access: amikor a folyóirat és a benne megjelent cikkek a szerző és felhasználó számára egyaránt ingyenesek.

Gold open access: a szerző (vagy az intézménye) közzétételi díjat fizet a folyóiratnak, ezáltal a kiadónak, a felhasználó viszont ingyenes jut hozzá a folyóirathoz.

Léteznek olyan kezdeményezések, melyek célja összegyüjteni az open access folyóiratokat és cikkeiket, valamint a kiadók és a folyóiratok szerzői archiválásra vonatkozó feltételeit:

DOAJ - „A Directory of Open Access Journals (DOAJ) egy nonprofit szervezet, amelynek legfontosabb szolgáltatása az az index, amely több mint 9000 lektorált, tudományos Open Access (OA) folyóirat adatait, illetve az ott megjelent cikkek metaadatait tartalmazza. A DOAJ által jegyzett folyóiratok mindegyike elbíráláson (https://doaj.org/application/new) esik át, mielőtt felkerülhetne a

15 Open Access - Tájékoztató a kutatási témapályázatot elnyert kedvezményezettek számára https://bit.ly/2OCtyHf 
listára. A DOAJ, a bevételeit kizárólag támogatásokból szerzi. A támogatók között 2018-ban több mint 100 egyetem és könyvtár, illetve 15 könyvtári konzorcium 26 országból. (https://doaj.org/members) Magyarországról egyelöre egyedül az MTA KIK tagja a szervezetnek."16

Sherpa/Romeo (Rights Metadata for Open archiving): http://www.sherpa.ac.uk/romeo/index.php

„A folyóiratok és a kiadók archiválási politikájára vonatkozó adatok gyüjtőoldala. Tartalmazza a kiadók politikájának összefoglalását, ideértve azokat az információkat is, hogy a cikk milyen verzióját, hova és milyen feltételek mellett lehet feltölteni." 17

Gold megjelentetés hibrid folyóiratban: a szerző a cikk ingyenes közzétételéért előfizetéses folyóiratoknak fizet.

Hibrid folyóirat - A szakirodalom "double dipping" néven is emlegeti ezt a fajta gazdasági magatartást. A folyóirat alapvetően az előfizetéses üzleti modellt használja, de lehetőséget ad az egyes cikkek nyílt hozzáférésű publikálására, ha a szerző azt megfizeti. A kiadók kétszer számolják fel az adott cikk előállítási költségeit: egyszer az előfizetési díj beszedésével, másodszor az opcionális nyílt hozzáférés díjával. A hibrid modell átmeneti módszernek tekinthető az előfizetéses és az open access kiadás között. Néhány kiadó enged a folyóirat előfizetési árából, amennyiben az open access opciót igénybe vevő cikkek százaléka elér egy bizonyos határt. ${ }^{18}$

\section{A szerzői archiválás (self-archiving) típusai}

\subsection{Az open access green útja}

A kézirat különböző fajtáinak vagy a megjelentett publikációnak az intézményi vagy tudományterületi repozitóriumba történő feltöltését jelenti. Ez történhet mechanizált folyamatokon keresztül, mikor egy létező adatbázisból emelik át a rekordot a repozitóriumba vagy történhet manuálisan, mikor a repozitórium regisztrált felhasználója, aki lehet szerzői vagy adatfeltöltő státuszban a szükséges mezők kiegészítését követően menti az adatokat. A kiadói politikák meghatározhatják, hogy a publikációt a megjelenésével egyidejüleg vagy az embargó idő lejárta után, utólag teheti nyilvánossá a szerző. Mivel a repozitóriumok elektronikus archívumok, ezért a szerző a publikáció megjelenési adatait bármikor nyilvánossá teheti a repozitóriumban is.

16 Információk a DOAJ tagságról: http://bit.ly/2OCx2tj

17 Sherpa/Romeo: GYIK - Kiadói copyright szerződések és szerzői archiválás https://bit.ly/2NjdQjI

18 A hibrid modell. Openscience.hu https://bit.ly/30Ijyi3 
A kiadók csak a teljes szöveg nyilvánossá tételében szabhatnak meg korlátozásokat.

A repozitóriumokkal szembeni egyik kritika szerint túlnyomó részt lektorálatlan
kéziratokat töltenek fel rájuk, melyek közül a legtöbb a későbbiekben sem esik át
szakértői bíálaton. Ugyanakkor az is tény, hogy sok olyan értékes dokumentu-
mot is megtalálhatunk rajtuk, melyek a repozitóriumok hiányában, hagyományos
nyomtatott formában vagy az internetre valamilyen ellenőrizetlen, hektikusan
müködő oldalra feltöltve kallódnának.
Repozitóriumokat a következő helyeken lehet keresni:
- OpenDOAR - Directory of Open Access Repositories http://www.opendoar.org/
- ROAR - Registry of Open Access Repositories http://roar.eprints.org/
- A Pécsi Tudományegyetem repozitóriuma a Pécsi Egyetemi Archívum (PEA).
A repozitórium üzemeltetése a PTE Egyetemi Könyvtár és Tudásközpont (PTE
EKTK) openaccessbutton.orgfeladata. http://pea.lib.pte.hu/

\subsection{A szürke út}

A repozitóriumokat sokszor kizárólagosan csak az open access mozgalom által megfogalmazott elektronikus archívumokként azonosítják, melyek a zöld (green) publikálási modell helyszínei. Elfelejtik, hogy a repozitóriumok valójában dokumentumszerverek, amelyek képesek más jellegü elektronikus dokumentumok tárolására is. A szürke út a szürke irodalom rendelkezésre bocsátását jelenti. A dokumentumok költségmentes használata a kiadók, illetve folyóiratok részvétele nélkül történik. Nem foglal magában sem utólag, sem elözetesen vagy egyidejüleg folyóiratban vagy kiadónál történő megjelenést. Az írásokat az elfogadott, lektorált kéziratokhoz vagy már kiadott publikációkhoz hasonlóan intézményi vagy tudományterületi repozitóriumba töltik fel a szerzők.

\section{A kiadók}

\section{A cikkek megjelentetésre és archiválásra vonatkozó kiadói open access politikák jellemzői}

A nagy múltra visszatekintő, elismert nemzetközi kiadók tisztában voltak azzal, hogy sikeres fennmaradásuk érdekében meg kell változtatniuk kiadói politikájukat, alkalmazkodva a nyílt hozzáférés kezdeményezés elveihez. A legtöbb vezető nemzetközi kiadó egészen 
hamar elkezdett open access publikációkat, később pedig folyóiratokat kiadni. A kiadók mindegyike igyekszik a saját és szerzőik érdekeit egyaránt figyelembe venni. Ám ennek következtében a több ezer folyóirat kiadásával foglalkozó vállalatok némi túlzással, de szinte mindegyik kiadványukra eltérő politikát, más-más árakat és jogi korlátozásokat határoznak meg.

A kiadók általában három: az arany, a zöld és a hibrid kategóriába sorolható kiadványt különböztetnek meg, amelyek többnyire párhuzamba vonhatók a vállalat kiadói politikájával. Az arany, vagyis gold publikációk esetében a felhasználó szemszögéböl egyértelmüen a teljes, térítésmentes, azonnali hozzáférésről beszélhetünk. A szerzők számára a cikk megjelentetése költségekkel jár, viszont az arany út biztosítja a pre- és posztprintek, valamint a kiadói változatok teljes szövegü archiválását is.

A kiadók a zöld úttal általában a publikációk egyes fázisaiban elérhető dokumentumok felhasználási jogait korlátozzák a szerzők számára. A legtöbb kiadó green publikálási politikája (amit ők gyakran self-archiving-nak neveznek) az elöfizetésen alapuló folyóiratok esetében érdekes. A self-archiving policy rendszerint engedélyezi a preprintek szabad felhasználását, míg a posztprintek esetében bizonyos embargóidőt határoznak meg. Vegyünk néhány példát. Az Oxford University Press 12 hónap embargóidőt határoz meg a tudományos, technológiai és orvostudományi, 2 év embargóidőt a bölcsészettudományi cikkekre vonatkozóan. A Springer Open hagyományos előfizetésen alapuló folyóiratai esetében például a pre-, valamint a posztprintek 12 hónappal a publikálást követően archiválhatók. Az Elsevier honlapján feltüntetett kiadói politikája engedélyezi a preprintek teljes szövegü archiválását a repozitóriumokban, a posztprintek is archiválhatók nullától egészen harminchat hónapig terjedő embargóidőn belül, folyóirattól függően.

A hibrid kiadványok esetében több ezer folyóiratról beszélünk, melyek egyszerre biztosítják szerzőik számára az open access és a hagyományos publikálás lehetőségétegyazon folyóiratban. Ezek a folyóiratok igen kedveltek a kiadóknál, hiszen duplán tudják értékesíteni őket. Egyrészt azáltal, hogy a szerzők vállalják a publikációs költségeket, másrészt azáltal, hogy az intézmények elöfizetnek a teljes tartalomra. ${ }^{19}$

19 Fekete Rita: Open access és a felsőoktatási könyvtárak feladatai. In: Tudományos és Müszaki Tájékoztatás vol. 62. iss. 5. pp. 171-176. 2015. http://bit.ly/3vu1TJ6 
A kiadók a gold cikkek közzétételért az elöfizetéses modellhez hasonlóan (open access) szerződéseket ajánlanak az intézményeknek. A szolgáltató gyakorlatától függ, hogy mit tartalmaznak ezek az ajánlatok. A szerződésben például meghatározhatják azokat a folyóiratokat, ahol az intézmény szerzői publikálhatnak. A szerződés tartalmától függ, hogy korlátlan vagy meghatározott cikkmennyiséget küldhet be a szerződő fél, vagyis az adott intézmény szerzői. Olyan lehetőség is van, ahol az intézmény fiókot nyit magának a kiadónál - mint egy bankszámlaszámot - vagy tagsági szerződést köt és a „feltöltött” pénzösszegekböl gazdálkodva biztosítja a szerzők open access publikálását. Magyarországon az Elektronikus Információs Szolgáltató Nemzeti Program (EISZ) a 2018-as évre két Read\&Publish jellegü szerződést kötött. A megállapodások keretében az előfizetéses tartalmak használata mellett bizonyos mennyiségü open access cikk publikálása is lehetséges. További tájékozódási lehetőség: http://bit.ly/3cxIKgL

\section{Az előfizetők ébredése}

Mindezidáig nem igazán tudott érvényesülni az open access mozgalom koncepciója és megint csak a kiadók jöttek ki jól a helyzetböl, hiszen továbbra is ök diktálnak. A hagyományos folyóiratok előfizetései (melyek árai ugyanúgy emelkednek) mellett a kiadók modelljébe bekerültek az APC-díjak is (melyek a hibrid folyóiratok esetében folyamatosan nőnek). Továbbra is az államilag támogatott intézmények fizetnek akár duplán is a hozzáférés biztosításáért. Ráadásul a kiadók még feltételeket is szabnak az elviekben szabad archiváláshoz.

Az igazsághoz az is hozzátartozik azonban, hogy évről évre emelkedik az open access folyóiratok száma. Az open access folyóiratok száma 2014-ben 39\%-al több volt, mint 2013-ban. Ezzel szemben a hagyományos előfizetésen alapuló folyóiratok száma 14\%-os csökkenést mutatott. Létezik olyan tudományterület, ahol a kiadói open accessnek egészen jól müködő gyakorlata van. A részecskefizikában a SCOAP3 projektnek köszönhetően az elöfizetéses folyóiratokról szinte teljesen áttértek a nyílt hozzáférésü periodikákra. ${ }^{20}$

2015-ben a Max Planck Digital Library azt vizsgálta, hogy globálisan hogyan lehet megvalósítani a kiadói open accessre történő átállást. Kutatási eredményeik alapján megállapították, hogy az előfizetésekre szánt összegek fedeznék a szerzők APC-díjait.. ${ }^{21}$

20 Holl András, Bilicsi Erika: Az Open Access és a sárgaköves út. In: Tudományos és Müszaki Tájékoztatás vol. 63. iss. 9. pp. 340-343. 2016. http://bit.ly/3bMFfUA

21 Holl András: Beszéljünk nyíltan a nyílt hozzáférésről!: Gondolatok Kovács Kármen A nyílt hozzáférésű (open access) publikálás néhány bizonytalan következménye címü cikke nyomán. In: Magyar Tudomány vol. 178. iss. 2. pp. 224-227. 2017. https://bit.ly/3bN0CFm 
„Az APC-alapú finanszírozás tudja megteremteni a folyóiratok közötti valódi versenyt, melyben a közlési díj nagysága a folyóirat által biztosított láthatóságtól, a várható idézettségtől függ."22

2018-ban eddig négy olyan európai konzorciumról tudunk, akik felbontották valamelyik nagy nemzetközi kiadóval kötött szerződésüket és megszüntették a hagyományos előfizetéses modellben müködő folyóirat előfizetéseiket. 2016-ban a német DEAL Projectben résztvevő több mint 60 nagy kutatóintézet volt az első, akik az Elsevierrel kötött előfizetésüket mondták le, ami 440 folyóirat teljes szövegü elérhetöségének végét jelentette. A résztvevő intézmények abban állapodtak meg, hogy ha a kutató számára nélkülözhetetlen egy adott cikk azt az intézménye megvásárolja neki. Nem kell mást tennie, mint a könyvtárnak jeleznie, hogy szüksége van a cikkre. Az Elsevier azóta is tárgyalásokat a folytat a konzorciummal és továbbra sem szüntette meg a teljes szövegü tartalmak hozzáférését. Két évet kellett várni arra, hogy további három ország is megtegye ezt a lépést. 2018-ban a Hollandiában müködő Association of Universities in the Netherlands (VSNU) lépett vissza a Royal Society of Chemistry Publishinggel kötött szerződéstöl, a svéd Bibsam Consortium az Elsevier, a francia Couperin a Springer Nature kiadókkal tette ugyanezt. ${ }^{23}$

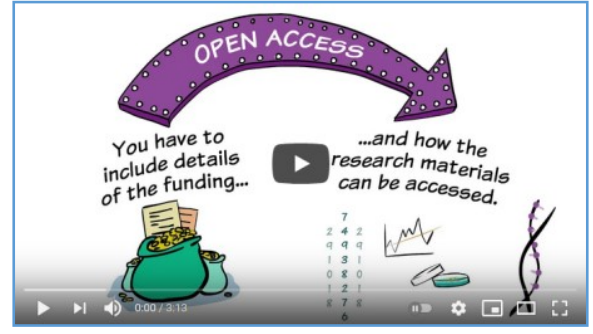

Forrás: https://youtu.be/cic3EVbekMk

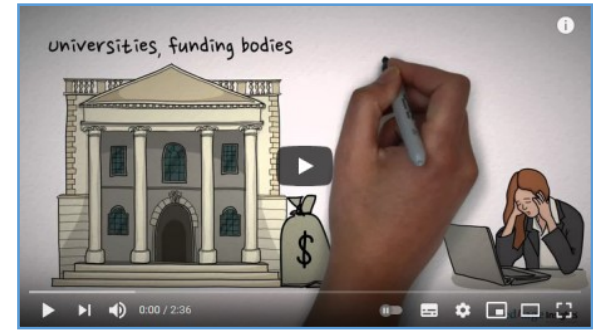

Forrás: https://youtu.be/o2HMouOV-Lg

22 Holl András, Bilicsi Erika: Az Open Access és a sárgaköves út. In: Tudományos és Müszaki Tájékoztatás vol. 63. iss. 9. pp. 341. 2016. http://bit.ly/2OSXCOH

23 Holly Else: Europe's open-access drive escalates as university stand-offs spread. In: Nature 2018. május 17. https://go.nature.com/3qPFWka; Joseph Esposito: Libraries Face a Future of Open Access. In: Scolarly Kitchen 2018. május 23. http://bit.ly/2Nn3kbi; Horváth Bence: Fellázadtak a német egyetemek és könyvtárak a szabad tudásért. In: 444.hu 2016. december 22. https://bit.ly/2OV1SgM; FÁK: Merész német bojkott a helyzetével visszaélő kiadó ellen. In: Index 2016.12.17. https://bit.ly/3qPxiCg 


\section{Sci-Hub a legismertebb kalózoldal}

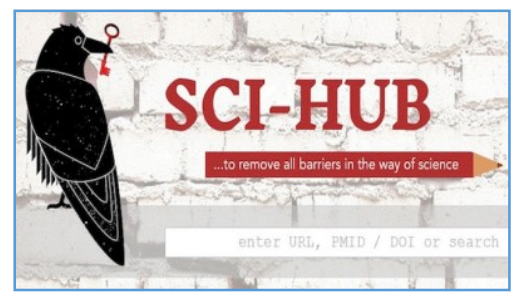

2. ábra $-\mathrm{Sci}-\mathrm{Hub}$

Sajnos a kiadók töretlen nyomulása a tudományos eredmények közreadásának torzulásához vezetett. Megjelentek a tudományos publikációk kalózoldalai, melyek illegális úton több millió cikkhez biztosítanak teljes szövegü hozzáférést. Alexandra Elbakyan, egy fiatal kazah származású hallgató - akit „a tudomány Robin Hoodja”-ként szoktak emlegetni - 2011-ben keltette életre a Sci-Hub nevü oldalt.

Az Elsevier kiadó 2015-ben a New Yorki bíróságon beperelte a kazah lányt. A vád nemzetközi kalózhálózat üzemeltetése, amivel 750-150000 dollár értékü kárt okozott a kiadóvállalatnak. habár a New Yorki bíróság megszüntette az oldalt Elbakyan folyamatosan változtatva annak domain nevét újra és újra elérhetővé teszi a SciHubot a világhálón.

Az oldalnak már 2016-ban is naponta több százezer látogatója volt a világ minden tájáról.

„2016 márciusáig félévnyi adathalmazt kaptak meg a cikkhez, ebböl pedig kiderült, hogy ennyi idő alatt több mint 28 millió dokumentumot töltöttek le az oldalon keresztül. A legnépszerübbek épp az Elseviernél megjelent publikációk voltak, ezekböl több mint félmilliót töltöttek le egyetlen hét alatt. [...] A félév alatt beérkező 28 millió letöltési kérelem hárommillió egyedi IP-címről érkezett, de a felhasználók ennél jóval többen lehetnek a Science becslése szerint is, mivel sok kérelem érkezhetett egyetemi IP-címekröl."24

„A 2015 szeptemberétől fél éven át zajló letöltések adatait megnézve az hamar kiderült, hogy az a gyakori állítás, hogy főleg a fejlődő országok diákjai és kutatói használják a Sci-Hubot, nem fedi pontosan a valóságot. A letöltések negyede 34 OECD-tagállamból jött, az ötödik legnagyobb letöltő ország pedig az USA volt, ahol az egyetemek többségén elérhetők lettek volna ezek az anyagok legálisan is." ${ }^{25}$

Elbakyan elismerte, hogy illegális tevékenységet folytat, ugyanakkor abszurdnak tartja, hogy egyetlen cikk akár 25-35 dollárba (7-10.000 forint) is kerülhet. Nem véletlenül döntött a Sci-Hub létrehozása mellett, hiszen hallgató társaival együtt nem fértek hozzá a kutatásaikhoz szükséges fontos szakirodalmi forrásokhoz. Elbakyan az ENSZ Em-

24 Horváth Bence: Fél év alatt Budapeströl 70 ezren töltöttek le tanulmányokat a legnagyobb tudományos kalózoldalról. In: 444.hu 2016. április 30. 25 http://bit.ly/3bN1AkY 
beri Jogi Nyilatkozatának 27-es pontjára hivatkozva (mindenkinek joga van szabadon részt venni közössége kulturális életében, élvezni a művészet és tudomány eredményeit) amellett is kiáll, hogy mindenkinek joga van hozzáférni a tudományos eredményekhez. ${ }^{26}$

Az idealista álmok megvalósítására törekvő Sci-Hub nem jelent megoldást. Az információk felelős és etikus felhasználásának kritériumaiba nem tartozik bele a kalózoldalak tevékenységének támogatása, éppen emiatt a használatuk nem is bátorítandó. Előbb-utóbb hasonlóan negatív következményei lehetnek, mint a kiadók agresszív profitorientált viselkedésének.

Abban az esetben, ha nagy szükségünk lenne egy cikkre, de az intézményünknek
nincs elöfizetése az adott folyóirathoz, és emiatt nincs teljes szövegü hozzáféré-
sünk nem kell kétségbe esnünk. Szerencsére léteznek alternatív - és mindenek-
elött legális! - megoldások is.
Unpaywall — https://unpaywall.org/
Az unpaywall a nonprofit Impactstory projekt ingyenes böngésző pluginja, ami
kiadók és repozitóriumok nyilvános és szabadon elérhető tartalmai között keres.
Openaccessbutton.org — https://openaccessbutton.org/
Online vagy a böngésző bővítményeként is használható ingyenes szolgálta-
tás. Elsősorban repozitóriumokba feltöltött tartalmakban keres.
EndNote Click — https://click.endnote.com/
A plugin repozitóriumokban és az intézményi előfizetésekben egyaránt ke-
res. A regisztrációt követően tárhelyet is biztosít, ahová lementhetők a cikkek.
Hagyományos módszereket tekintve még mindig maradhatunk a könyvtár-
közi kölcsönzéseknél. A következő módszernek jogilag ugyan vannak megkérdö-
jelezhető aspektusai, mégis sok helyen bevett gyakorlata van a kutatói közösségi
oldalak (ResearchGate, Academia.edu) használatának, ahol akár a szerzőtől is el
lehet kérni a publikációt.

\subsection{A lecke ismeretlen fogalmainak magyarázatai}

\section{Creative Commons}

A Creative Commons egy nonprofit szervezet, ami számos CC licenc fajta kiadásáért felelős. Használatukkal a szerzőnek megmaradnak a jogai miközben másoknak a licenc által meghatározott feltételek mentén bizonyos fokú szabad felhasználást biztosít. Ilyen például a másolatok készítése, a mủvek nem kereskedelmi célú terjesztése feltüntetve a cikk tulajdonosát, aki maga a szerző. A licenc amellett, hogy megvédi a szerzői jogokat lehetőséget teremt a cikk szabad fel-

26 LICA: A tudósok is kénytelenek kalózkodni. In: index.hu 2016.02.15. http://bit.ly/3bNH43B 
használására. A folyóirat szerkesztőségek lehetőséget biztosítanak a szerzőnek a licenc kiválasztására. ${ }^{27}$

\section{Elektronikus Információs Szolgáltató Nemzeti Program (EISZ)}

Konzorciális keretek között müködő program, amely a magyarországi elektronikus tartalomszolgáltatásért felelős. Tagjai államigazgatási intézmények, egészségügyi intézmények, felsőoktatási intézmények, közkönyvtárak, levéltárak, a Magyar Tudományos Akadémia, múzeumok, nonprofit kutatóintézetek és szakkönyvtárak. A Nemzeti Program állami támogatása mellett a résztvevő intézményeknek is vállalniuk kell bizonyos önrészt az adatbázis előfizetésekből.

\section{Embargó idő}

Embargó időnek nevezzük azt az időszakot, amíg egy kézirat vagy publikáció egyáltalán nem vagy csak egy zárt felhasználói kör számára válik szabadon felhasználhatóvá.

\section{Interoperabilitás elve}

„A különböző informatikai rendszerek együttmüködésre való képessége. Az együttműködés különböző szinteken valósulhat meg. Technikai interoperabilitásról akkor beszélünk, ha a rendszerek között fizikailag lehetséges az adatcsere, és az egyik rendszerből a másikba eljuttatott információ a rendszert használó ember számára értelmezhető. A szemantikus interoperabilitás szintjén nemcsak fizikailag lehetséges az adatcsere, hanem a rendszerek egymás adatait „értelmezni” is tudják. Ez azt jelenti, hogy a küldő rendszerben keletkezett adat olyan módon kerül át a fogadó rendszerbe, hogy a fogadó rendszer ugyanolyan müveleteket tud rajta végezni, mintha az adat a fogadó rendszerben keletkezett volna, és a rendszer felhasználók is ilyen módon tudják az adatot használni." ${ }^{28}$

\section{Kiadói szerzödés}

Kiadói szerződés alapján a szerző köteles a müvet a kiadó rendelkezésére bocsátani, a kiadó pedig jogosult azt kiadni, valamint forga-

27 Racskó Réka: Virtuális könyvtárak. Eszterházy Károly Főiskola. Tankönyvtár https://bit.ly/3bNhnA5

28 Interoperabilitás. In: Egészségtudományi Fogalomtár. http://bit.ly/3bOBApr 
lomba hozni és köteles a szerzőnek díjat fizetni. A kiadói szerződés a felhasználási szerződés egyik típusa, melyben a szerző engedélyt ad mủvének felhasználására a kiadó számára. ${ }^{29}$

\section{Levelezö szerzö}

A levelező szerző (aki lehet az első vagy az utolsó szerző is) az a személy, aki a cikk benyújtásától egészen a megjelentetéséig vállalja és egyben felelös is a folyóirat szerkesztőségével történő kapcsolattartásért. ${ }^{30}$

\section{Megjelenési adatok}

A könyvtártudományi szaknyelvben összegzően csak megjelenési adatoknak nevezzük a kiadvány megjelenésének a helyét, a kiadó nevét, az oldalszámot, a kiadás évét, a dokumentumtípushoz tartozó azonosítókat.

\section{Metaadat}

„Az adatról szóló információt metaadatnak nevezzük. A metaadat legegyszerübb definíciója: adat az adatról. Pontosabban, a metaadat írja le az adatot, azaz olyan információkkal szolgál, mint típus, hos-szúság, szöveges leírás és más jellemzők. Ez a meghatározás az elektronikus információforrások megjelenésével lépett életbe, és kezdetben azokban a szabványokban tủnt fel, amelyek az elektronikus információforrások azonosításában, leírásában és megtalálásában voltak hasznosak. A fogalom egyre inkább elterjedt, mivel számos, ún. nem hagyományos dokumentumformátumra alkalmazták, aminek eredményeképpen a metaadatsémák sokasodni kezdtek.

Bár a kifejezést először digitális információkkal kapcsolatban használták, jelentése azóta általánossá vált és kibővült, így magában foglalja az információforrások valamennyi szabványos leírását - beleértve a nem digitális dokumentumokét is. Példák lehetnek erre könyvtári katalógusok, referáló és indexelő szolgáltatások, valamint levéltári keresőeszközök." 31

29 1999. évi LXXVI. tv. 42.§ (1) és 56.§ (1) bek. https://bit.ly/30M8uRe

30 Braunitzer Gábor: A tudományos közlemények szerzöségének néhány etikai és jogi vonatkozásáról. In: Magyar Orvosi Nyelv vol. 15 iss. 1. pp. 21-28. 2015. http://bit.ly/3tmp7Pz

31 Vágner Anikó, Juhász István: Adatbázis-adminisztráció. Digitális Tankönyvtár. https://bit.ly/3qTfRkm; Magda El-Sherbini, George Klim: Metadata and cata- 


\section{Önarchiválás/szerzői archiválás}

„Az önarchiválásnak vagy szerzői archiválásnak nevezik a publikációk egyéni, nem szabványos módon történő megőrzését/tárolását és megjelenését jelenti például egy tanszék, intézmény vagy a szerző saját honlapján. Az open access szakirodalomban elsősorban az intézményi repozitóriumba való feltöltésre vonatkozik."32

\section{Preprint}

„A preprint a digitális korszak elött kialakult tipikus szürkeirodalom: kisebb példányszámban nyomtatott, szükebb körben terjesztett, az új eredményeket a hagyományos kiadást megelőző - vagy elkerülő -, gyors tájékoztatási forma. Tulajdonképpen a cikk első benyújtott (unrefereed), még nem elfogadott és nem lektorált változata(i). A bírálati folyamat során keletkező javított, módosított változatok még preprintek, egészen a kiadói szerkesztésre benyújtottig (final accepted draft)."33

\section{Posztprint}

„Postprint (posztprint): a hivatalosan is elfogadott, helyesebben a referensek véleménye alapján módosított, a kiadói szerkesztésre benyújtott kézirat; továbbá minden más, a kiadási folyamatban keletkezett változat a kiadottal megegyező másolatokig terjedően; ezeken túl, az utólagos módosításokkal közzétett szövegekig valamennyi változat." ${ }^{\text {34 }}$

\section{Read\&Publish megállapodások}

A nemzetközi terminológiában read\&publish-nak nevezték el azt a szerződés típust, melynek keretében az előfizetéses tartalmak használata (vagyis olvasása (read)) mellett a kiadó folyóirataiban bizonyos mennyiségü open access cikk publikálása is lehetséges az előfizető intézmények szerzői számára.

loguing practices $=$ Metaadatok és katalogizálási gyakorlatok (ford.) Berke Barnabásné. In: Tudományos és Müszaki Tájékoztatás vol. 53. iss. 2. pp. 77-88. 2006. http://bit.ly/3rOEsbi

32 A jogi felelősség veszélyei önarchiválás során. Openscience.hu https://bit.ly/3vuOuAz

33 Dudás Anikó: A tudományos kiadási eljárás kéziratváltozatainak terminológiája. In: Tudományos és Müszaki Tájékoztatás vol. 60. iss. 10-12. pp. 469 és 473474. 2016. http://bit.ly/3vqTFkZ

34 Uott. 


\section{Repozitórium}

„A repozitórium egyetemeken és kutatási intézményekben müködő dokumentumszerver, amely tudományos anyagok archiválására és világszerte díjmentes hozzáférhetővé tételére szolgál. Intézményi és diszciplináris repozitóriumokat különböztetünk meg." ${ }^{35}$

\section{SCOAP3 projekt}

Az Európai Nukleáris Kutatási Szervezet (CERN) által indított program, amely vállalja a részecskefizika területén született publikációk open access közlését. Az APC, vagyis a publikációs díjak költségét egy könyvtárakból és finanszírozó testületekből álló nemzetközi konzorcium vállalja. Magyarországon az Elektronikus Információs Szolgáltató Nemzeti Program (EISZ), illetve az MTA Open Access alapja $50-50 \%$ arányban állja a SCOAP3 tagdíjat. A projekt első fázisa 2014-2016 között volt, míg a második 2017-től 2019-ig tartott. ${ }^{36}$

\section{Szerzői jog}

Jogterület, mely a polgári jog sajátos, önálló része. A szerzői jog a szellemitulajdon-védelem területén belül főleg az irodalom, müvészet és tudomány körébe tartozó egyéni, eredeti alkotások (művek) szerzőit ösztönzi az alkotásra és védi azok szerzők jogait, azaz biztosítja számukra a személyhez füződő és a vagyoni jogok összességét. A szerzői jog célja, hogy egyensúlyt teremtsen a szerzők, a felhasználók és a társadalom érdekei között. ${ }^{37}$

\section{Szürke irodalom}

„Tudományos szürkeirodalomnak tartjuk - a teljes terjedelmű írásmüveknek csupán néhány jellegzetesebb fajtáját említve - a konferenciák résztvevőin kívül mások számára nem terjesztett kötetet

35 Repozitóriumok. Openscience.hu https://bit.ly/2OVQWzv

36 Gaálné Kalydy Dóra, Molnár Andrea, Vas Viktória (összeállította): A Magyar Tudományos Akadémia Könyvtárának 2016. évi beszámoló jelentése https://bit.ly/3qQQWht

37 Hargitai József: Jogi Fogalomtár. Budapest: Magyar Hivatalos Közlönykiadó 2005. pp. 1393., Hepp Nóra, Fejesné Lőrincz Anna: Szerzői jog. Budapest: Szellemi Tulajdon Nemzeti Hivatal 2012., Tattay Levente, Pintz György, Pogácsás Anett: Szellemi Alkotások Joga. Budapest: Szent István Társulat Az Apostoli Szentszék Könyvkiadója 2017. 
(nyomtatvány, CD, DVD), a disszertációkat, a kutatási jelentéseket, a müszaki dokumentációt, a be nem jegyeztetett, nemzetközi szabványos azonosítók (ISBN, ISSN, DOI) nélküli kiadványokat; a könyvtári hálózatban körülményesen elérhető vagy a kereskedelembe és a szolgáltatásokba be sem kerülő, az indexelő-referálóknál nem nyilvántartott dokumentumokat; a preprinteket és az egyéb efemer dolgozatokat. Szürkeirodalom a nem lektorált publikáció, a szerzői kiadású mű és valamennyi, a tudományos kiadás normáinak betartása nélkül közreadott közlemény - például a kiadatlan, ám interneten valahol publikussá tett cikk, a weboldalra, szakmai blogra feltöltött tanulmány stb. Ezek a dokumentumok tudományos érték szempontjából is „szürkék”, a tudományos teljesítményi követelményrendszerekből is kitetszik, hogy szakmai súlyuk lényegesen kisebb, mint a bibliotékákban és a tudományos indexelő és tartalomszolgáltatóknál hozzáférhető, lektorált, referált, ISBN-nel, ISSN-nel, kiadói impresszummal ellátott formális publikációké."’38

\section{Tudományos lektorálás}

„A tudományos lektorálás folyamata során a tanulmányt más, megfelelő szakértelemmel rendelkező kutatók értékelik. A tudományos lektorálás több lépcsőben és változatos módon zajlik. E folyamat közös eleme a közlésre benyújtott írás alapos vizsgálata előre megállapított tartalmi és formai kritériumok alapján (mint például a téma időszerüsége, a tudományos kutatás minősége, a szöveg tudományos nyelvi stílusa, a hivatkozások megfelelő volta stb.). A lektorálási szempontok alapvetően két kérdésre keresik a választ: mennyiben járul hozzá az adott kutatás a szakterület fejlődéséhez, és beleillik-e a közlemény a folyóirat arculatába tartalmilag és formailag." ${ }^{39}$

\subsection{Felhasznált irodalom}

1. Kristin Yiotis: The Open Access Initiative: A new paradigm for scholarly com-munications $=$ A nyílt hozzáférés kezdeményezés: a tudományos kommuni-káció új paradigmája (ford.) Bánhegyi Zsolt.

Dudás Anikó: A tudományos kiadási eljárás kéziratváltozatainak terminológiája. In: Tudományos és Müszaki Tájékoztatás vol. 60. iss. 10-12. pp. 463-479. 2016. http://bit.ly/3vqTFkZ

39 Hajnal Ward Judit: Ki szavatol a ...? Helyzetjelentés a tudományos lektorálás állásáról. In: Könyvtári Figyelö vol. 58. iss. 4. pp. 713-714. 2012. https://bit.ly/3cwkbAZ 
In: Tudományos és Müszaki Tá-jékoztatás vol. 53.iss. 3.pp. 141-142. 2006. http://bit.ly/3bPxux2

2. arXiv.org. In: konyv.guru http://bit.ly/2Q86pNp; Holl András: A nyílt hozzáfé-rés nemzetközi és hazai áttekintése. In: Könyv és nevelés vol. 15. iss. 2. pp. 23-28. 2013. https://bit.ly/3tiNRbu; Bánhegyi Zsolt: Nyílt Hozzáférés Kezdemé-nyezés (Open Access Initiative) Kitekintés és körkép. In: Tudományos és Müszaki Tájékoztatás vol. 50. iss. 6-7. pp. 236-249. 2003. http://bit.ly/3tm4bs5

3. Holl András: A nyílt hozzáférés nemzetközi és hazai áttekintése. In: Könyv és nevelés vol. 15. iss. 2. pp. 23-28. 2013. https://bit.ly/3tiNRbu

4. Bajomi Bálint: Hagyományos versus Open Access publikálás. In: Ökológiai Blog - Az MTA Ökológiai Kutatóközpont blogja http://bit.ly/2Q5SO9n

5. Kristin Yiotis: The Open Access Initiative: A new paradigm for scholarly com-munications $=$ A nyílt hozzáférés kezdeményezés: a tudományos kommuni-káció új paradigmája/ (ford.) Bánhegyi Zsolt. In: Tudományos és Müszaki Tá-jékoztatás vol. 53. iss. 3.pp. 141-142. 2006. http://bit.ly/3bPxux2; Koltay Ti-bor, Tóth Erika: A tudományos publikációkhoz való szabad hozzáférés iro-dalma Magyarországon. In: Tudományos és Müszaki Tájékoztatás vol. 53. iss. 3. pp. 128-132. 2006. http://bit.ly/3bNGqTZ

6. the Santa $\mathrm{Fe}$ Convention for the Open Archives Initiative http://bit.ly/30NZH0U

7. Budapesti felhívás a szabad hozzáférés érdekében http://bit.ly/3tkdGrz

8. Bethesda Statement on Open Access Publishing https://bit.ly/3bNZ261

9. Berlini Nyilatkozat a tudomány nyílt eléréséről https://bit.ly/38Fqotf

10. Börzsönyi Nóra: Hozzáférhető tudomány: Az open access és az értéknövelt publikációk világa a könyvtári gyakorlat tükrében. https://bit.ly/2Oyqb43; Ko-vács Kármen: A nyílt hozzáférés (open access) publikálás néhány bizonytalan következménye. In: Magyar Tudomány vol. 178. iss. 1.pp. 71-79. 2017. https://bit.ly/38CY3Uk

11. Open Access - tudástár. Nemzeti Kutatási, Fejlesztési és Innovációs Hivatal https://bit.ly/2OysSmj

12. Open Access - tudástár. Nemzeti Kutatási, Fejlesztési és Innovációs Hivatal https://bit.ly/2OysSmj

13. Uott.

14. Repozitóriumok. Openscience.hu https://bit.ly/2OVQWzv

15. Open Access - Tájékoztató a kutatási témapályázatot elnyert kedvezménye-zettek számára https://bit.ly/2OCtyHf

16. Információk a DOAJ tagságról: http://bit.ly/2OCx2tj

17. Sherpa/Romeo: GYIK - Kiadói copyright szerződések és szerzői archiválás https://bit.ly/2NjdQjI

18. A hibrid modell. Openscience.hu https://bit.ly/30Ijyi3 
19. Fekete Rita: Open access és a felsőoktatási könyvtárak feladatai. In: Tudo-mányos és Müszaki Tájékoztatás vol. 62. iss. 5. pp. 171-176. 2015. http://bit.ly/3vu1TJ6

20. Holl András, Bilicsi Erika: Az Open Access és a sárgaköves út. In: Tudományos és Müszaki Tájékoztatás vol. 63. iss. 9. pp. 340-343. 2016. http://bit.ly/3bMFfUA

21. Holl András: Beszéljünk nyíltan a nyílt hozzáférésről!: Gondolatok Kovács Kármen A nyílt hozzáférésű (open access) publikálás néhány bizonytalan kö-vetkezménye címü cikke nyomán. In: Magyar Tudomány vol. 178. iss. 2. pp. 224-227. 2017. https://bit.ly/3bN0CFm

22. Holl András, Bilicsi Erika: Az Open Access és a sárgaköves út. In: Tudományos és Müszaki Tájékoztatás vol. 63. iss. 9. pp. 341. 2016. http://bit.ly/2OSXCOH

23. Holly Else: Europe's open-access drive escalates as university standoffs spre-ad. In: Nature 2018. május 17. https:/go.nature.com/3qPFWka; Joseph Espo-sito: Libraries Face a Future of Open Access. In: Scolarly Kitchen 2018. május 23. http://bit.ly/2Nn3kbi; Horváth Bence: Fellázadtak a német egyetemek és könyvtárak a szabad tudásért. In: 444.hu 2016. december 22. https://bit.ly/2OV1SgM; FÁK: Merész német bojkott a helyzetével visszaélő kiadó ellen. In: Index 2016.12.17. https://bit.ly/3qPxiCg

24. Horváth Bence: Fél év alatt Budapestről 70 ezren töltöttek le tanulmányokat a legnagyobb tudományos kalózoldalról. In: 444.hu 2016. április 30. http://bit.ly/3bN1AkY

25. Uott.

26. LICA: A tudósok is kénytelenek kalózkodni. In: index.hu 2016.02.15. http://bit.ly/3bNH43B

27. Racskó Réka: Virtuális könyvtárak. Eszterházy Károly Főiskola. Tankönyvtár https://bit.ly/3bNhnA5

28. Interoperabilitás. In: Egészségtudományi Fogalomtár. http://bit.ly/3bOBApr

29. 1999. évi LXXVI. tv. 42.§ (1) és 56.§ (1) bek. https://bit.ly/30M8uRe

30. Braunitzer Gábor: A tudományos közlemények szerzőségének néhány etikai és jogi vonatkozásáról. In: Magyar Orvosi Nyelv vol. 15 iss. 1. pp. 21-28. 2015. http://bit.ly/3tmp7Pz

31. Vágner Anikó, Juhász István: Adatbázis-adminisztráció. Digitális Tankönyvtár. https://bit.ly/3qTfRkm; Magda El-Sherbini, George Klim: Metadata and cata-loguing practices $=$ Metaadatok és katalogizálási gyakorlatok (ford.) Berke Barnabásné. In: Tudományos és Müszaki Tájékoztatás vol. 53. iss. 2. pp. 77-88. 2006. http://bit.ly/3rOEsbi

32. A jogi felelősség veszélyei önarchiválás során. Openscience.hu https://bit.ly/3vuOuAz

33. Dudás Anikó: A tudományos kiadási eljárás kéziratváltozatainak terminológi-ája. In: Tudományos és Müszaki Tájékoztatás vol. 60. iss. 10-12. pp. 469 és 473-474. 2016. http://bit.ly/3vqTFkZ 
34. Uott.

35. Repozitóriumok. Openscience.hu https://bit.ly/2OVQWzv

36. Gaálné Kalydy Dóra, Molnár Andrea, Vas Viktória (összeállította): A Magyar Tudományos Akadémia Könyvtárának 2016. évi beszámoló jelentése https://bit.ly/3qQQWht

37. Hargitai József: Jogi Fogalomtár. Budapest: Magyar Hivatalos Közlönykiadó 2005. pp. 1393., Hepp Nóra, Fejesné Lőrincz Anna: Szerzői jog. Budapest: Szellemi Tulajdon Nemzeti Hivatal 2012., Tattay Levente, Pintz György, Pogá-csás Anett: Szellemi Alkotások Joga. Budapest: Szent István Társulat Az Apos-toli Szentszék Könyvkiadója 2017.

38. Dudás Anikó: A tudományos kiadási eljárás kéziratváltozatainak terminológi-ája. In: Tudományos és Müszaki Tájékoztatás vol. 60. iss. 10-12. pp. 463-479. 2016. http://bit.ly/3vqTFkZ

39. Hajnal Ward Judit: Ki szavatol a ...? Helyzetjelentés a tudományos lektorálás állásáról. In: Könyvtári Figyelő vol. 58. iss. 4. pp. 713-714. 2012. https://bit.ly/3cwkbAZ

\section{8. Összefoglalás}

Az Open Access Mozgalom irányelveinek megfogalmazása jelentős változásokat eredményezett a tudományos publikálásban. A nyílt hozzáférést sokan hajlamosak csak a publikálás módjának változásaival, az open access folyóiratok (gold open access) és a repozitóriumok (szerzői archiválás/green open access) megjelenésével azonosítani. Ez részben a kiadók gyors reagálásának számlájára írható, mivel ahelyett, hogy segítették volna az open access világszintü megvalósulását olyan kiadói politikákat hoztak létre, melyek következtében részben elveszett a nyílt hozzáférés mozgalom eszmeiségének lényege és ismét a kiadók agresszív üzleti politikájával találtuk szemben magunkat. Egyre több országban kezdik felismerni a tarthatatlan állapotokat és inkább vállaljak, hogy nemzeti szintü open access stratégiák mentén szervezik meg a tudományos publikálás közreadását. Az előfizető intézmények mellett a kutatók is elégedetlenségüket fejezik; a Sci-Hub nevü publikációs kalózoldal felhasználóinak száma évről-évre a növekvő tendenciát mutat. Fontos hangsúlyoznunk, hogy a tudományos eredmények és ismeretek közvagyonként történő kezelésének eszméje erősödni látszik az Open Science Mozgalom égisze alatt. 


\section{9. Önellenőrző kérdések}

Melyik az Open Access Mozgalom három legfontosabb és legmeghatározóbb dokumentuma?

A Budapesti Open Access Initiative manifesztuma, a Bethesda Nyilatkozat és a Berlini Nyilatkozat.

A Budapesti Open Access Initiative manifesztum milyen stratégiákat javasol a tudományos folyóirat-irodalomhoz való szabad hozzáférés érdekében?

A válasz a lecke „A Budapest Open Access Initiative (BOAI)” c. bekezdésében található.

Miben különbözik a hagyományos és az open access publikálási modell?

A helyes válasz a lecke „A publikálás módja” c. bekezdésében található.

Mi az a hibrid folyóirat?

A helyes válasz a lecke „A publikálás módja” c. bekezdésében található.

Milyen célt szolgál az embargó idő?

Elsősorban a kiadók védik ezzel az előfizetéses tartalmaikat. Az embargó idő meghatározásával korlátozzák a cikk a nyilvános és szabad elérhetőségét, ezzel elérve, hogy a felhasználó kénytelen legyen megvásárolni vagy elöfizetni a teljes tartalomra.

Melyik projekt biztositja a részecskefizikában, hogy az elöfizetéses folyóiratokról áttérjenek a nyilt hozzáférésü periodikákra?

\section{SCOAP3}

Milyen legális források segítségével keresne kéziratokat vagy teljes szövegü lektorált publikációkat?

DOAJ, Unpaywall, openaccessbutton.org, Kopernio 


\subsection{Tesztkérdések}

\section{Mi az Open Access Mozgalom célja?}

[ ] Költségek nélkül mindenki ingyenesen férjen hozzá a tudományos tartalmakhoz.

[•] Korlátozás nélkül, szabadon elérhetővé tenni a tudományos ismeretek.

[ ] Megtörni az Elsevier nemzetközi kiadó hatalmát.

[ ] Minél több online archívum létrehozása.

2. Melyik dokumentum fogalmazta meg elöször az Open Access Mozgalom alapelveit?

[ ] A Budapest Konvenció

[ ] A Bethesda Nyilatkozat

[•] A Budapest Open Access Initiative (BOAI)

[ ] A Budapest Open Access Institute (BOAI)

3. Mi az a repozitórium?

[ ] XML-protokoll

[ ] Metaadat gyüjtő szerver

[ ] Elektronikus könyvtár

$[\bullet]$ Dokumentumszerver

\section{Mi a repozitóriumok célja?}

[•] A tudományos anyagok archiválása és díjmentes hozzáférhetővé tétele

[ ] A tudósok levelezéseinek összegyüjtése

[ ] A természettudósok kéziratainak közös szerveren történő tárolása

[ ] Az egyetemi oktatók cikkeinek díjmentes hozzáférését szolgáló szerver legyen

\section{Mik azok a nyílt hozzáférésü dokumentumok?}

[ ] A könyvtárak által előfizetett, de a felhasználók számára ingyenes tartalmak

[•] A felhasználók számára díjmentesen hozzáférhető tudományos ismeretek

[ ] A repozitóriumba feltöltött publikációk

[ ] A lektorálás előtti kéziratok 


\section{Mi az Article Processing Charge?}

[ ] A szerzők ennek az összegnek a kifizetésével vásárolják vissza a szerzői jogot

[ ] Az open access cikkekre elkülönített összeg

[ ] Közzétételi dij, amit a szerző azért fizet, hogy a cikkét elfogadja a folyóirat

[•] Az open access publikációkért fizetett közzétételi díj

\section{Hogyan lehet open access módon publikálni?}

[•] Open access vagy hibrid folyóiratokban és szerzői archiválás útján

[ ] Csak Article Processing Charge ellenében

[ ] Csak repozitóriumban

[ ] Csak folyóiratban

\section{Mi az a Creative Commons?}

[ ] Nonprofit intézmény, ami olyan licencek kiadásáért felelős, amelyek feltétel nélküli szabad felhasználást biztosítanak a felhasználóknak.

[•] Nonprofit intézmény, ami olyan licencek kiadásáért felelős, melyek meghatározott feltételek mentén biztosítják a publikációk szabad felhasználását úgy, hogy közben megmaradnak a szerzők jogai.

[ ] Nonprofit intézmény, ami olyan licencek kiadásáért felelös, amelyek lehetővé teszik a cikkek kereskedelmi célú terjesztését.

[ ] Nonprofit intézmény, ami olyan licencek kiadásáért felelös, amelyek a rendelkezésére álló szerzői jogokkal szabályozza a cikkek a terjesztésére vonatkozó feltételeket. 


\section{PREDÁTOR KEZDEMÉNYEZÉSEK}

\section{Bevezetö gondolatok}

A tananyag válogatott szakirodalom feldolgozásával mutatja be az Open Access Mozgalom egyik negatív hatásaként jelentkező predátor kezdeményezéseket; ismerteti a kifejezés jelentését, valamint összegzi a predátor tevékenységek legfontosabb típusait és jellemzőit. A hallgató a lecke tanulása közben megismeri a szélhámosok által használt módszereket és trükköket, melyek figyelmen kívül hagyásával a szerző áldozatául eshet a predátor törekvéseknek. Végül, olyan jó gyakorlatokra találhatnak példát a hallgatók, melyek segítségükre lehetnek a predátor kezdeményezések felismerésében.

\section{Célok, megszerezhetö kompetenciák}

A leckében található ismeretanyag (a predátor tevékenységek típusai és jellemzői) elsajátítása képessé teszi a hallgatót arra, hogy a későbbiekben önállóan is képes legyen (1) felismerni a tudományos tevékenyégének megítélésére veszélyt jelentő kiadókat, folyóiratok, mutatószámokat, valamint konferenciákat, fórumokat; (2) felismerni és használni azokat a forrásokat, amelyek segíthetik őt abban, hogy bizonytalan felkeresések és hirdetések esetén a számára legkedvezőbb döntést hozza meg. A lecke tehát mindenekelött a résztvevő kritikai gondolkodásmódját kívánja fejleszteni.

\section{Szükséges eszközök, források}

Jól működő asztali vagy hordozható számítógép és internetkapcsolat, melyek segítségével a hallgató megnézheti azoknak a kampányjellegü projekteknek a weboldalát, ahol útmutatásokat és jó gyakorlat talál arra vonatkozóan, hogy hogyan tudja azonosítani és elkerülni a predátor megkereséseket.

\section{Feldolgozási idö}

- 90 perc

\section{Témakörök}

- Bevezetés

- Fogalom magyarázatok

- A predátor folyóirat-kiadás jellemzői és árulkodó jelei 
- „Hijacked journals”, avagy a megtévesztő folyóiratok

- „Misleading metrics”, avagy a félrevezető mutatószámok

- Predátor konferenciák

- A predátor kezdeményezések ,áldozatai”: a veszélyeztetettek

- Következmények

- Lehetőségek

\section{Irodalmak}

- Carolyn Yucha: Predatory Publishing: What Authors, Reviewers, and Editors Need to Know. In: Biological Research for Nursing. Vol. 17. Iss. 1. pp. 5-7. 2015. https://bit.ly/2Q77c17

- Hajnal Ward Judit: A tudomány élősködői. Denveri beszélgetés Jeffrey Beall-lel. In: Könyv, könyvtár, könyvtáros. vol. 25. iss. 9. pp. 916. 2016. https://bit.ly/3qP2wd0

- Hajnal Ward Judit: Vétkesek közt: parazita folyóiratok, kiadók és konferenciák. In: Orvosi Könyvtárak vol. 15. iss. 1. pp. 14-21. 2018. https://bit.ly/38KM2MO

- Jacqueline K. Owens: Predatory Publishing Practices: More Trend sin Predatory Publishing Practices. In: Nurse Author \& Editor vol. 25. iss. 1. Paper NAE-2015-25-1-3-Owens, 2015. https://bit.ly/3qRBmlD

- Jeffrey Beall: Criteria for Determining Predatory Open-Access Publishers. Manuscript https://bit.ly/38GHGpZ

- Jeffrey Beall: Dangerous Predatory Publishers Threaten Medical Research. In: Journal of Korean Medical Science vol. 31. iss. 10. pp. 1511-1513. 2016. https://bit.ly/3eKEleq

- Jeffrey Beall: Essential Information about Predatory Publishers and Journals. In: International Higher Education iss. 86. pp. 2-3. 2016. https://bit.ly/38JO93h

- Jeffrey Beall: Writer's Forum-Predatory journals, peer review, and education research. In: New Horizons in Adult Education \& Human Resource Development vol. 29. iss. 1. pp. 54-58. 2017. https://bit.ly/2Q6fmqy

- Martin Paul Eve, John Willinsky: Open access in humanities and social sciences: Visions for the future publsihing. In: College \& Research Libraries News vol. 76. iss. 2. pp. 88-91. 2015. https://bit.ly/3vqq7Ec

- Matti Myllykoski: Open access in the eyes of its sharpest critic: an interview of Jeffrey Beall. In: Journal of EAHIL vol. 12. iss. 2. pp. 20-24. 2016. https://bit.ly/38GI73B

- Monica Berger, Jill Cirasella: Beyond Beall's List: Better understanding predatory publishers. In: College \& Research Libraries News vol. 76. iss. 3. pp. 132-135. 2015. https://bit.ly/31kLGBx

- Pooja Dewan, Dheeraj Shah: A Writer's Dilemma: Where to Publish and Where not to? In: Indian Pediatrics vol. 53. pp. 141-145. 2016. https://bit.ly/3eKEBsC 


\subsection{Bevezetés}

Az előző lecke végén elkezdtünk foglalkozni az Open Access Mozgalom hatásaival és következményeivel. A tananyag ezen fejezete külön tárgyalja a tudományos kommunikáció forradalmában kialakult predátor kezdeményezéseket, melyek kialakulását kétségkívül az Open Access Mozgalom idézte elő. A tudományos életben megjelenő szélhámosok leginkább a tudományos ismeretek és a kutatási eredmények pénzért történő közzétételében véltek felfedezni potenciált. Míg korábban a felhasználó fizetett az elöfizetésekért, az open access publikációk megjelentetésért a szerzőknek kell fizetniük. Ez jó alapot biztosított ahhoz, hogy a cikkek befogadását követően, de még a kiadásuk előtt nagyobb összeget kérjenek el a gyanútlan, sokszor tapasztalatlan szerzőktől anélkül, hogy a folyóiratok szerkesztőségei bármilyen érdemi munkát fel tudnának mutatni. Az idők során egyre kifinomultabb érdekek és motivációk kezdték hajtani a csalókat. Ilyen volt például predátor folyóiratokban publikált cikkekkel történő státusz-szerzés.

\subsection{Fogalom magyarázatok}

\section{Predátor kezdeményezés}

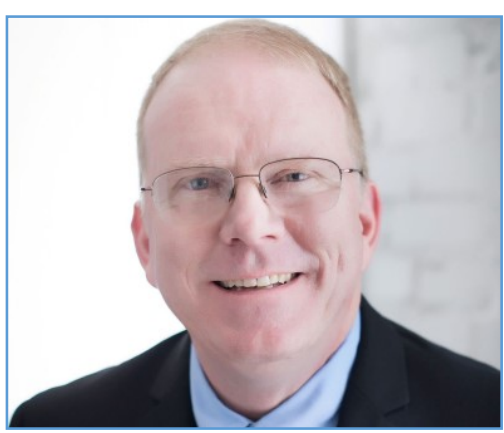

1. kép - Jeffrey Beall

Azoknak a kiadóknak, folyóiratoknak, konferenciáknak és egyéb tudományos vagy áltudományos tevékenység köré épülő szerveződéseknek az összefoglaló megnevezése, melyek valamilyen érdek mentén próbálják rávenni a gyanútlan szerzőket a publikálásra vagy konferencia-részvételre. A kezdetben elsősorban anyagi haszon miatt létrejött kiadók és folyóiratok mára sokkal kifinomultabb szempontokat vesznek figyelembe megalakulásukkor. Létezik folyóirat, melynek szerkesztőbizottsági tagjai minél gyorsabban szeretnének előléptetéshez jutni, emiatt létrehoztak egy olyan folyóiratot, ahol szerzőtársaikkal egymást hivatkozzák. S olyan esetről is tudhatunk, mikor az emberek egészségével játszadozva eredmények hamisításával próbáltak új gyógyszert bevezetni, eladhatóvá tenni. A mára intézményesült csoportosulások tevékenységeinek számos jellemzői vannak, melyek ismeretében bárki elkerülheti, hogy áldozatául essen nekik. 
Jeffrey Beall a predátor folyóirat-kiadás névadója 2000-től 2018 márciusáig a University of Colorado Denver, Auraria Library docense és könyvtárosa volt. Elmondása alapján 2008-2009 között figyelt fel először a predátor kezdeményezésekre, mikor a habilitálására készült. Ebben az időszakban mindamellett, hogy tudatosan kutatta a potenciális folyóiratok címeit, ahol publikálhat, számos kéretlen spam üzenetet kapott kétes eredetü folyóirat-szerkesztőségektől. Beall hasonlóságot és tendenciát vélt felfedezni az e-mailekben, melyeket hamar elkezdett archiválni. 2009-ben létrehozott blogján, - ahol a „potenciális, lehetséges és valószínűleg predátor folyóiratokat és kiadókat" - gyüjtötte kezdetben csak 18 folyóirat szerepelt, melyek száma alig néhány év alatt 923-ra emelkedett. A 2017 januárjában megszünt blogon predátor kiadók és folyóiratok, megtévesztő folyóiratok (hijacked journal) és félrevezető mutatószámok (misleading metrics) szerepeltek. Az időközben megszünt blogjának címe és URL címe: Scholarly Open Access (Tudományos nyílt hozzáférés) scholarlyoa.com. A frissített tartalom jelenleg itt érhető el: Beall's List of Predatory Journals and Publishers https://beallslist.net/

\section{Predátor vagy parazita?}

Az angol nyelvű szakirodalomban a Jeffrey Beall által használt predátor megnevezés terjedt el, viszont a hazai szakirodalomban gyakran találkozhatunk a szinonimájaként használt parazita kifejezéssel. Mindkét szó elsősorban az élővilágban használatos jelentéstartalommal bír. Míg előbbi a ragadozókra jellemző támadásra utal, utóbbi az élősködő magatartásra helyezi a hangsúlyt. Magyarországon mindkét terminus technicus elfogadott és használt, azonban a nemzetközi fórumokon ne lepődjünk meg, ha kezdetben nem értik mikor parazita folyóiratokról beszélünk.

\subsection{A predátor folyóirat-kiadás jellemzői és árulkodó jelei}

Jeffrey Beall gyüjtötte össze és publikálta elöször a predátor folyóirat-kiadás áltanos ismertetőjegyeit. Lényegében a témával kapcsolatos legtöbb közlemény öt ismétli, mikor összegzi ezeket a tulajdonságokat, amiket itt is sorra vesszünk.

\section{Spam üzenetek}

Ahogy a kitekintésben is olvasható, Jeffrey Beall is spam üzenetek kapcsán figyelt fel a gyanús próbálkozásokra. 
- Bevett szokás, hogy a kiadó vagy folyóirat kéretlen emailekkel keresi meg a szerzőket cikkért folyamodva, és csak később a cikk megjelentetése után szólnak, hogy fizetni kell.

- Általában a periodika első évfolyamának első lapszámába invitálják a szerzőt.

- Az e-mail címeik ingyenes szolgáltatók neveire végződnek: yahoo.com, gmail.com

Remek és kifejező példákat olvashatunk Hajnal Ward Judit cikkében arról, hogy hogyan építik fel üzeneteiket a megszólítástól egészen az aláírásig1:

A címzettek megszólítása korántsem illeszkedik a hivatalos levélváltás követelményeihez:

Mélyen tisztelt Dr. XY! Drága kutató! Drága tudós! Drága nagyrabecsült professzor!

A kezdősorok még szórakoztatóbbak. Íme egy csokor:

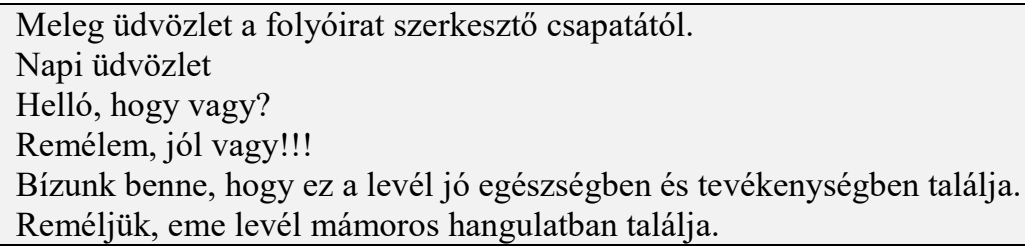

A levél rendre behízelgő és dicsérő hangvételü. A levélíró gyakorta inkább az egekbe magasztalja a címzettet, hol diszkrétebb, hol pedig kevésbé ízléses módon:

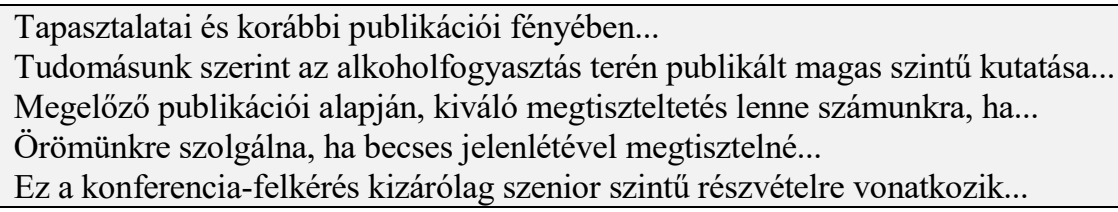

Egyértelmüen kiderül, hogy nem az angol az anyanyelvük, de még az is, hogy gépi fordítást alkalmaznak. Meg-megesik az is, hogy az angol nyelv kötött szórendjének ismerete hiányában nem világos, hogy a szerzőt avagy inkább önmagukat dicsérik, így egy füst alatt letudják

1 Hajnal Ward Judit: Parazita lapok - tudomány élősködői. In: Könyv, könyvtár, könyvtáros. vol. 25. iss. 9. pp. 17-25. 2016. https://bit.ly/3qPdWgL 
mind a kettőt. A levelekből később aztán kiderül, a füst nagyobb, mint a láng.

Nagy megtiszteltetés és kiváltság számunkra, hogy egy ilyen eminens szerzőt
kérhetünk fel...
Felkérjük, hogy csatlakozzon köztiszteletnek örvendő szerkesztőbizottságunkhoz,
és segítsen abban, hogy lapunk kirobbanó siker legyen...
Ebben az ünnepi szezonban ajándékozza meg önmagát a tudományos előrejutás
örömével...
Egy pillantást vetettünk kutatómunkájára, ami igen lenyűgözte rangos folyóira-
tunk kiváló szerkesztőségét...

Jókívánságaik felettébb mulattatóak is lehetnek. A záró sorok interkulturális változatossága egyszerüen lenyügöző. A szelídebbek szakmai és egyéni sikereket kívánnak korra, nemre és vérmérsékletre való tekintet nélkül:

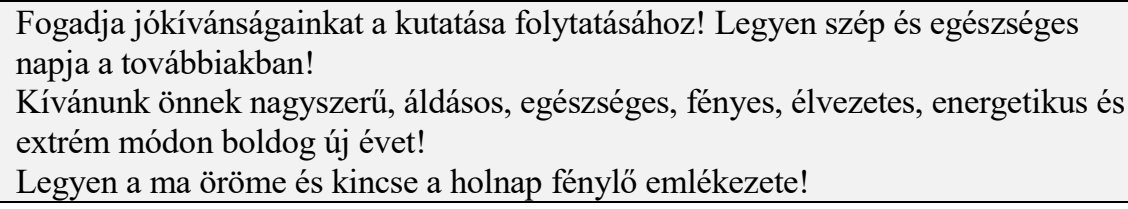

\title{
S végül a szerkesztő biztosság tagjai:
}

\begin{abstract}
Nem maradhat el a változatos szerkesztői névsor. Természetesen nevekkel nem szolgálunk; legyen elég annyi, hogy leggyakrabban ázsiai neveket láttunk. A kreatívabbak (vagy szellemesebbek?) további trükkökhöz folyamodván inkább nyugati neveket választottak. Végül is álnév, nem mindegy? Kedvencünk a két nyugati keresztnév rendes vezetéknév nélkül (mint Mária Magdolna), a nyugati keresztnév és ázsiai vezetéknév kombinációja (mondjuk, Jessica Yu), és, ha hiszik, ha nem: Sophia Loren, mint a meghívót küldő tudományos folyóirat szerkesztője! Az igazsághoz tartozik, hogy a neves müvésznő nem diszkriminált. Intézetünk minden egyes tagja kapott tőle legalább egy felkérő levelet, beleértve a titkárnőt és a kisegítő személyzetet is.
\end{abstract}

\section{Nyelvhelyesség}

- A spam üzeneteikre és a honlapjaikra egyaránt jellemző a szegényes nyelvhasználat és az angol nyelvtudás hiánya vagy pontatlan használata.

- Sokszor gépi fordítással készítik el az üzenetek és a honlapok szövegezését is. 


\section{Hamis telephelyek}

- Az általuk megadott címek általában bérházakhoz, lakóházakhoz, építkezési területekhez és bevásárlóközpontokhoz vezetnek.

- Többnyire nyugati székhelyet tüntetnek fel, de ténylegesen a fejlődő országokban müködnek.

\section{A kiadványok címe}

- A folyóirat címe rendszerint nincs összhangban a folyóirat küldetésével.

- A kiadó székhelye, amit a címben megadnak, nem illeszkedik a folyóirat nevéhez („Canadian”, „Swiss”, „American”).

- Nagyon hasonló egy nagy presztízsü folyóiratéhoz.

- Túl általános és túl nagy tudományterületet jelölnek (pl. Journal of Education), hogy minél több cikket tudjanak megjelentetni.

- Szerepel benne az open szó (utalva az open access-re), ami angolul furcsa jelentéstartalommal ruházza fel a folyóiratot: Open Heart Failure Journal (mintha a nyitott szív elégtelenül funkcionálna a zárthoz képest) lásd: Hajnal W. Judit

- Szerepel benne a „global” vagy „universal” kifejezés.

- Össze nem illő tudományterületeket kombinálnak: International Journal of Business, Humanities and Technology

- Másik, már létező folyóirat területét fedik le.

\section{Szerkesztő bizottság}

- Ugyanaz a szerkesztő bizottság szerepel több folyóiratnál.

- Nem tüntetnek fel elérhetőséget.

- Szerkesztőbizottságuk kicsi.

- Nincs bizonyíték arra, hogy a szerkesztők a tudományterület elismert kutatói.

- Hamis vagy nem létező intézményéket társítanak a bizottsági tagok nevei mellé.

- Engedély és hozzájárulás nélkül tüntetik fel az adott szakterület neves tudósainak nevét és arcképét.

- Nemek szerinti részrehajlás.

- Kicsi vagy nem létező földrajzi távolság a tagok között, holott a folyóirat megnevezésében szerepel az ,international” kifejezés.

- Sehol nem található publikált írása a tagoknak.

- Kitalált, nem létező vagy félrevezető mutatók használata: 
- Azt állítják, hogy a folyóiratnak van Impakt faktor száma, de a Clarivate Analytics által szolgáltatott Journal Citation Reports-ban nem található.

- További, nem létező mutatószámokat tüntetnek fel a honlapjukon. (Ezekről a kitalált, nem létező és félrevezető mutatókról a lecke további részében még lesz szó.)

\section{Rosszul karbantartott honlap}

- A honlapjaikon nem müködő linkek, rengeteg hirdetés, feltünő elírások és nyelvhelyességi hibák találhatóak.

- Olyan szolgáltatók logóit helyezik el a weboldalon, akikkel nincs is kapcsolatuk. Belefuthatunk az EBSCOhost, a Scopus, a Directory of Open Access Journals (DOAJ) és még számos más szolgáltató cégjelzésébe.

- A honlapon általában nem találunk leírást:

- a szerkesztői bizottságról,

- a publikálás folyamatáról,

- a formai és tartalmi követelményekröl,

- a lektorálási eljárásról,

- a korábbi számokról,

- a publikálási díjról és a számlázásról,

- a kiadói open access politikáról,

- a kiadó digitális megőrzésre vonatkozó gyakorlatáról és politikájáról.

- Helytelenül vagy rosszul használnak olyan nemzetközi azonosítókat, mint a DOI vagy az ISSN.

- A kiadó nevében benne van a network, association, institute, de a név nincs összhangban az intézmény non-profit jellegével.

\section{Lektorálás}

- A cikkeket válogatás és előzetes bírálás nélkül gyorsan fogadják el.

- A szakmai lektorálás minimális vagy nem létező; mellőzése nélkül pedig szinte azonnali megjelentetésre lehet számítani.

- Az elv: aki fizet, annak megjelenhet a cikke.

A cikkek tartalmi minösége

- A publikált tartalmak nem felelnek meg a tudományosság kritériumainak. 
- A folyóiratban megjelent cikkek tartalomban eltérnek a folyóirat tudományterületétől.

\section{Referálásuk, indexelésük}

A folyóiratokat nem referálja egyetlen nagyobb adatbázis sem. Ahogy korábban említettük vigyázni kell a honlapon megjelenő logókkal is. Sajnos az sem jelent garanciát, ha bizonyos adatbázisokban mégis megtaláljuk a folyóiratot. Remek példát olvashatunk ezekről Hajnal Ward Judit interjújában, amit Jeffrey Beall-el készített²:

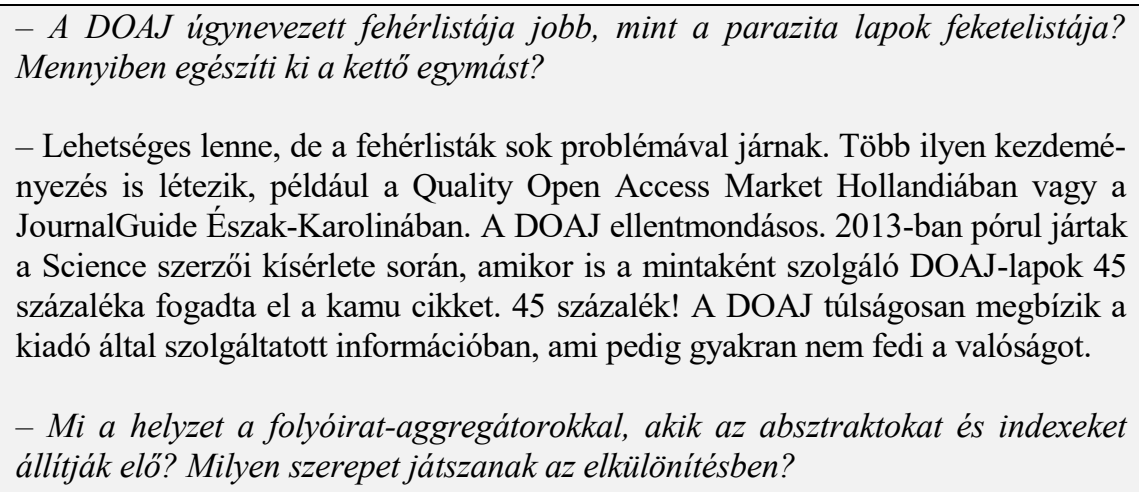

- Lehetséges lenne, de a fehérlisták sok problémával járnak. Több ilyen kezdeményezés is létezik, például a Quality Open Access Market Hollandiában vagy a JournalGuide Észak-Karolinában. A DOAJ ellentmondásos. 2013-ban pórul jártak a Science szerzői kísérlete során, amikor is a mintaként szolgáló DOAJ-lapok 45 százaléka fogadta el a kamu cikket. 45 százalék! A DOAJ túlságosan megbízik a kiadó által szolgáltatott információban, ami pedig gyakran nem fedi a valóságot.

- Mi a helyzet a folyóirat-aggregátorokkal, akik az absztraktokat és indexeket állitják elö? Milyen szerepet játszanak az elkülönitésben?

- A probléma részeseivé váltak. Ott vagyunk a könyvtáros konferencián, elmegyünk az EBSCO-ebédre, nézzük a diákat, ahogy büszkén mutogatják, milyen sok folyóirat tartozik hozzájuk. Nekik az az érdekük, hogy minél több lapot tehessenek be az adatbázisukba. Hogy elmondhassák, nekünk több van, mint a Scopusnak, és a Scopus azt mondhassa, nekünk több van, mint az EBSCO-nak. Érdekük, hogy minél nagyobb legyen az adatbázis. És mivel nagy a verseny az indexek között, a parazita lapok is bekerülnek.

- Komolyan? Akkor, ha mondjuk, az Academic Search Premierben keresgél az ember, belebotlik esetleg?

- Nem az a legrosszabb, de van néhány olyan cím benne, aminek nem lenne szabad ott lennie. Egyébként meg szinte mindegyik parazita lap honlapján ott díszeleg az EBSCO címere.

- Mi a helyzet az amerikai állami pályázati pénzekböl finanszírozott kutatás ingyeneses hozzáférhetővé tételével? Közpénz, tehát mindenki számára legyen elérhetö?

- Aki a pénzt adja, joggal szabhat feltételeket. Viszont a PubMed és PubMed Central adatbázisokat fenntartó National Center for Biotechnology Information nem végez valami jó munkát a parazita folyóiratok kigyomlálása terén. Teljes

2 Hajnal Ward Judit: A tudomány élősködői. Denveri beszélgetés Jeffrey Beall-lel. In: Könyv, könyvtár, könyvtáros. vol. 25. iss. 9. pp. 9-16. 2016. https://bit.ly/3qP2wd0 
csőd az egész. És a probléma egyre növekszik. Ami rendkívül veszélyes, mivel szoros kapcsolatban állnak a kutatásokat finanszírozó intézményekkel. Nem a legjobb üzenet a tudósok számára. Amikor mi könyvtárosok azt mondjuk, hogy abban a folyóiratban mégsem kéne publikálni, akkor a tudós jogosan mondhatja, hogy... De hát benne van a PubMedben! A PubMed nem fehérlista, és nem lenne szabad fehérlistaként használni. Csak a MEDLINE-t szabad fehérlistaként használni. De próbáld meg erről meggyőzni a tudósokat! A MEDLINE egy alaposan karbantartott gyüjtemény.

(részlet az interjúból)

DOAJ 2015-ben felülvizsgálta és szigorította azokat a kritériumokat, amik alapján a folyóiratok felkerülhettek a listájára. A rá következő évben azonban még ezt követően is a folyóiratok közel $10 \%$-a szerepelt Beall listáján. ${ }^{3}$

$\mathrm{Az}$ is gyanús jelenség, ha nem található meg egyetlen nagyobb könyvtár online katalógusában sem a folyóirat.

További megerősító érv lehet a túl sok önhivatkozás, ha a PDF tartalma nem másolható vagy szerkeszthetö, illetve ha a cikkek szerzöi jogát (copyright) a kiadók maguknak tartják meg. Hiszen az utóbbi két példa meröben ellent mond az open access mozgalom alapelveinek.

\section{4. „Hijacked journals”, avagy a megtévesztő folyóiratok}

A predátor és a megtévesztő folyóiratok között kevés különbség van. Mindkét lapnak ugyanaz a célja: megkörnyékezni a gyanútlan szerzőket. Azonban míg a predátor kiadók teljesen új folyóiratokat találnak ki, addig a megtévesztő folyóiratok tulajdonképpen lemásolnak, „klónoznak” egy már létező folyóiratot. Az eredeti (1. ábra) folyóiratcímhez hasonló vagy teljesen megegyező címeik vannak. Lemásolják a folyóirat logóját, színvilágát és képi megjelenését, de még a szerzői útmutatókat (author guideline) is képesek egészében átemelni a saját honlapjukra. Marketing kifejezéssel élve a folyóirat teljes „brand”-jét átveszik. (2. ábra)

3 Matti Myllykoski: Open access in the eyes of its sharpest critic: an interview of Jeffrey Beall. In: Journal of EAHIL vol. 12. iss. 2. pp. 20-24. 2016. https://bit.ly/38GI73B 


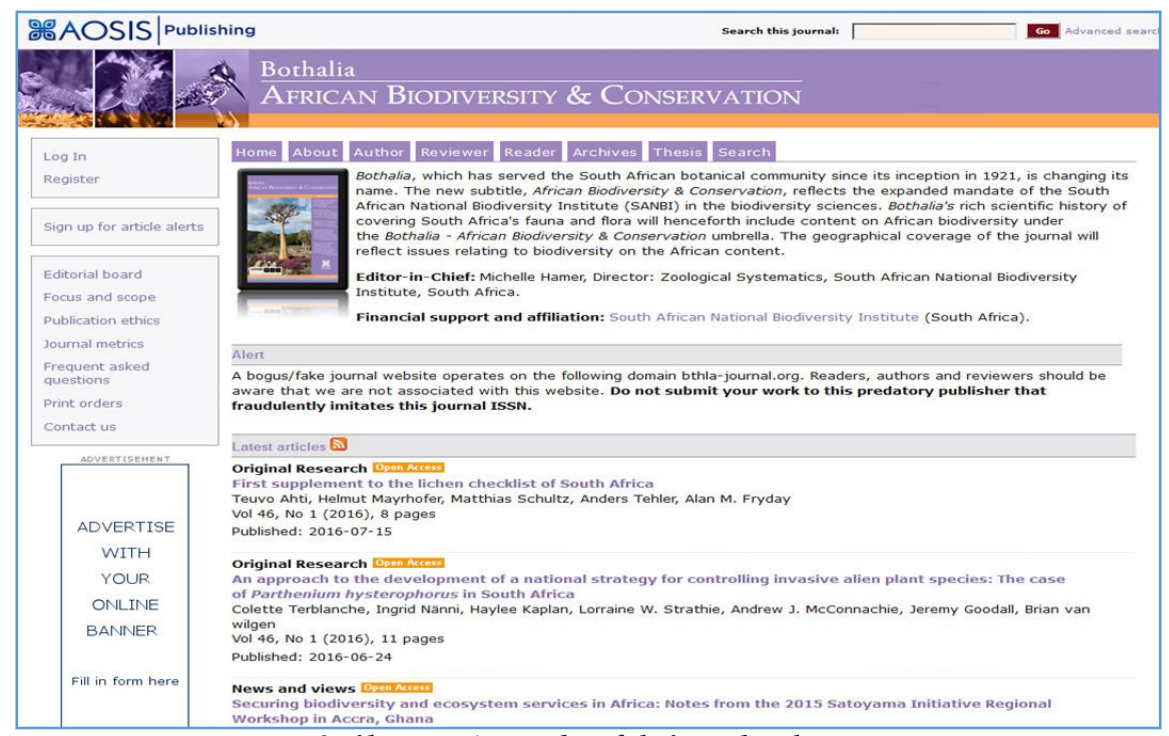

\section{1. ábra - Az eredeti folyóirat honlapja}

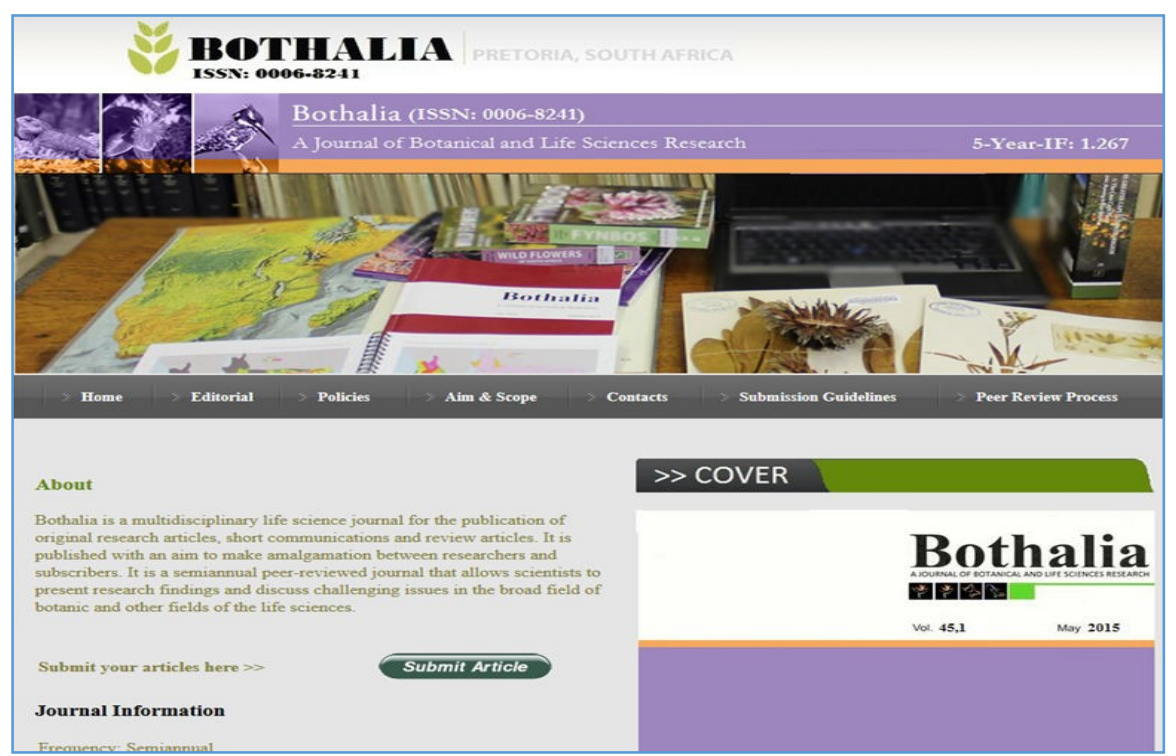

2. ábra - A hijacked folyóirat honlapja

\section{5. „Misleading metrics”, avagy a félrevezető mutatószámok}

A folyóiratokban történő publikálás fontosságának megítélése tudományterületenként eltérö, ahogy annak jelentősége is, hogy milyen periodikában jelentetik meg a szerzők a közleményeiket. Léteznek úgynevezett tudománymetriai mutatók, amik az időszaki kiadványok adott szakterületekre gyakorolt hatását mérik. Napjainkban több teljesítményérté- 
kelő módszer létezik, a teljesség igénye nélkül felsorolva néhány ismertebb mutatót: Impakt faktor, Eigenfactor, Scimago Journal Rankings (SJR), Citescore. A predátor kiadók jelentős része ismeri azokat a tudományterületeket, ahol a folyóiratoknak meghatározó szerepük van. Tisztában vannak azzal is, hogy a publikálási kényszer hatására mekkora nyomás nehezedik a szerzőkre. Éppen ezért nagyon sokan feltüntetik a honlapjukon a Clarivate Analytics által szolgáltatott Impakt faktort vagy az Elsevier tulajdonában lévő SJR értékeket. Jellemző, hogy hamis méröszámokat találnak ki, amiknek neve gyakran tartalmazza az „impact”, a „factor” vagy az ,impact factor” kifejezéseket. Lásd: Universal impact factor, Global impact factor. A mutatókat szolgáltató cégekről általában kevés vagy semmilyen információ nem áll rendelkezésre, a folyóiratokat nem az előre meghatározott kritériumok és a kidolgozott metodika alapján, hanem pénzösszeg ellenében veszik fel a listájukra. A metrika, már ha létezik egyáltalán, átláthatatlan, a számítási módszer nem eredeti vagy tudománytalan, ezenkívül az sem ritka, hogy a folyóiratok értékei évröl-évre növekvő tendenciát mutatnak.

\subsection{Predátor konferenciák}

A tudományos közlés fórumainak egészét behálózták a csalók. A kiadók, folyóiratok és metrikák mellett predátor konferenciákat is regisztrálnak. (3. és 4. ábra) Az egyik legnagyobb veszélyt a predátor folyóirat-kiadáshoz hasonlóan az anyagi károkozás jelenti.

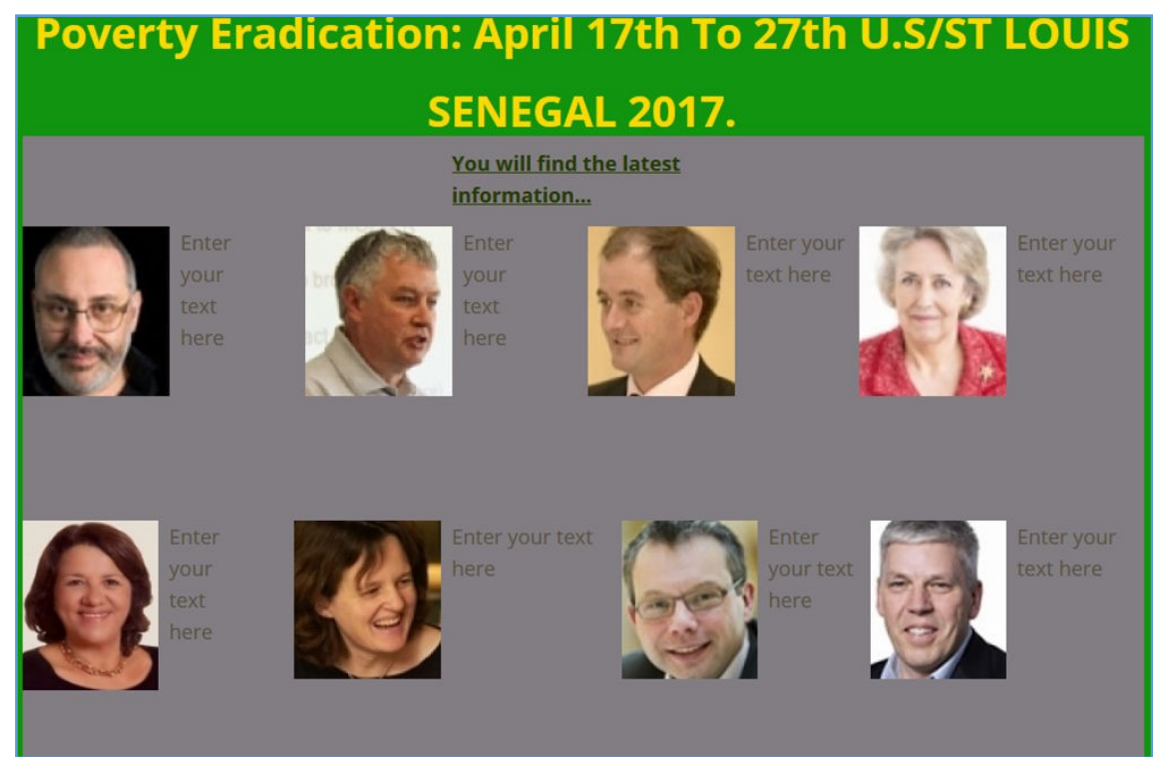

3. ábra - Egy predátor konferencia honlapja 


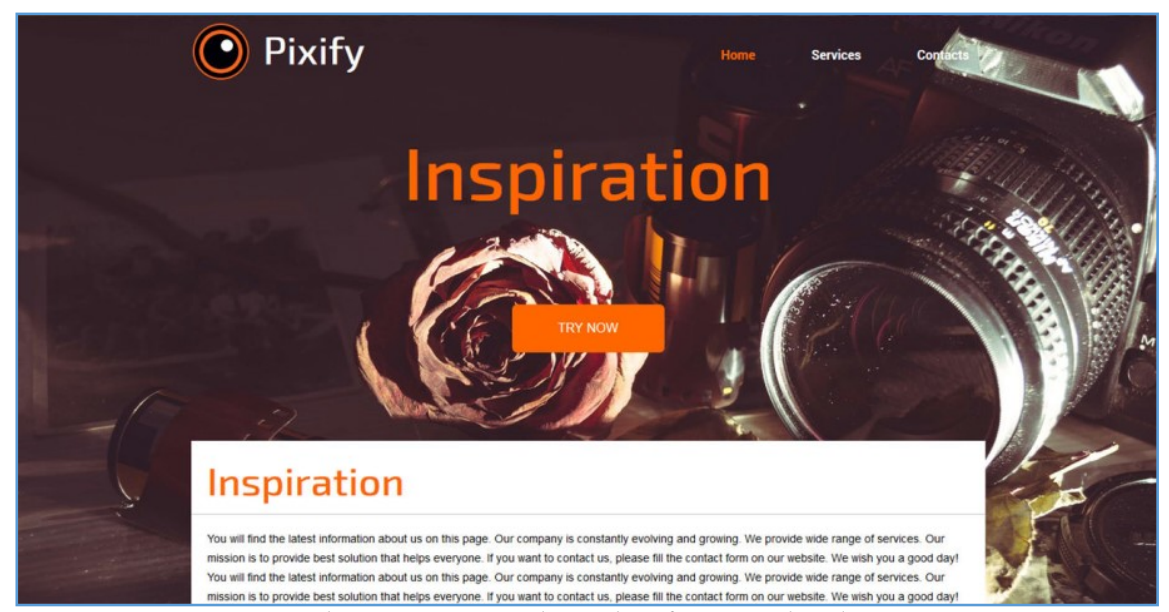

4. ábra - Egy predátor konferencia honlapja

Sajnos számolnunk kell azzal a lehetőséggel, hogy a meghirdetett rendezvény időpontját visszavonják, viszont a résztvevők által befizetett összeget nem utalják vissza. A konferenciákat gyakran maguk a predátor kiadók szervezik. Néhány konferenciaszervező és kiadó megállapodást köt arról, hogy a konferencián elhangzott előadások a kiadó predátor lapjában fognak megjelenni. Van, hogy ugyanazon hotelben egy időpontban több konferenciát tartanak teljesen különböző tudományterületek témáiban. Szintén bevett gyakorlat, hogy a tudtuk nélkül a szakterületek neves professzorainak a neveit tüntetik fel előadóként vagy a szekciók vezetöiként.

Mi magunk is bármikor áldozatul eshetünk egy ilyen felhívásnak. A PTE Neveléstudományi Doktori Iskola egyik hallgatója kereste fel könyvtárunkat, továbbítva a következő konferencia felhívást:

Dear Colleagues,

It is a great pleasure to invite you to the International conference on Rural Development, children's Rights In Education And Poverty Eradication (R.D.R.I.E.P.E 2017) which will be held from April 17th to 20th 2017 in New York United States of America and from 23rd to 27th 2017 in St Louis Senegal. This conference is one of the most highly acclaimed meetings in Rural Development \& Child's Rights.

This conference will provides opportunities for the delegates to exchange new ideas and application experiences face to face,to establish business or research relations and to find global partners for future collaboration. Earlier we had conferences held at London (UK),Singapore, Kuala Lumpur, Penang, Jakarta, Bali, Batam, Bangkok etc.

The organizing committee is gearing up for an exciting and informative conference program including plenary lectures, symposia, workshops on a variety of topics, poster presentations and various social programs for over 3,000 participants from around the world.

The conference welcomes paper presentation from any interested participants 


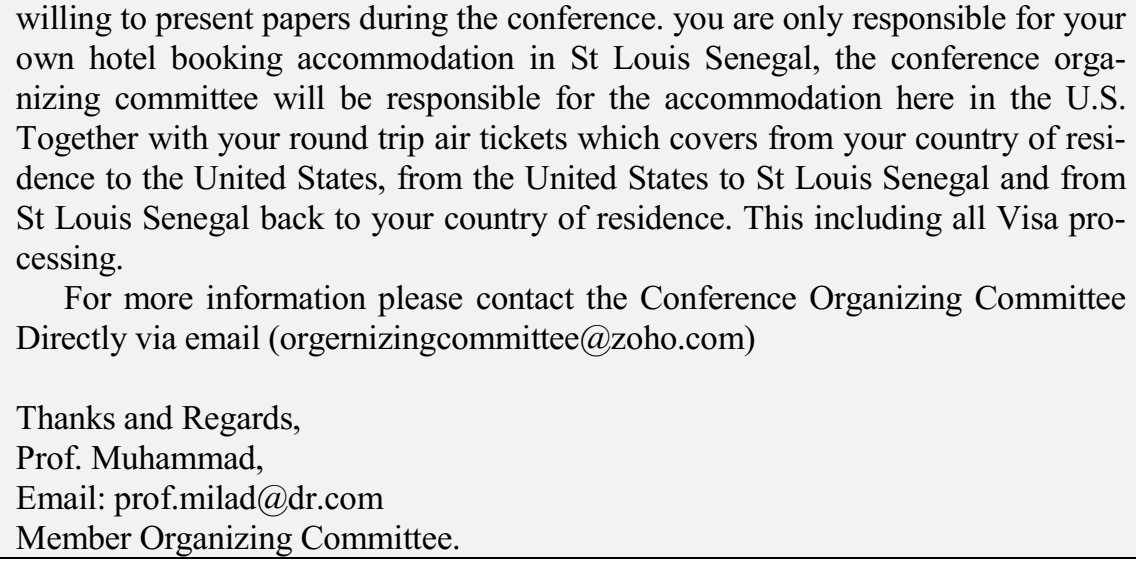
own hotel booking accommodation in St Louis Senegal, the conference organizing committee will be responsible for the accommodation here in the U.S. Together with your round trip air tickets which covers from your country of residence to the United States, from the United States to St Louis Senegal and from St Louis Senegal back to your country of residence. This including all Visa processing.

For more information please contact the Conference Organizing Committee Directly via email (orgernizingcommittee@zoho.com)

Thanks and Regards, Prof. Muhammad, Email:prof.milad@dr.com Member Organizing Committee.

A hallgató egyedül nem tudta eldönteni, hogy jelentkezzen-e a konferenciára. A konferenciának akkor még müködő honlappal a következő URL címen lehetett utánanézni: http://rdcriepe.org/ Az interneten keresgélve nem találtunk utalást arra vonatkozóan, hogy az előző években rendeztek volna konferenciát. Sem szervezőként, sem támogatóként nem állt mögötte nagyobb tudományos köztestület vagy akadémiai intézmény. A Bizottság tagjai a képeken láthatóan európai és észak-amerikai arcvonásokkal rendelkeztek. 2017. február 15-én még arab hangzású nevek voltak a képek mellé írva. Február 28-án már nem volt mellettük név. A megadott e-mail címek is furcsák voltak: prof.milad@dr.com, orgernizingcommittee@zoho.com

A hallgatónak azt javasoltuk, hogy ne vegyen részt a konferencián. Alig néhány hét leforgása alatt, még bőven a rendezvény meghirdetett időpontja előtt szépen lassan megszünt az oldal és eltünt, mintha soha nem is létezett volna. Azóta sem találtunk róla több információt, mint amennyit ennek a honlapnak a megnyitásával láthatunk: https://uia.org/content/22921 


\subsection{A predátor kezdeményezések ,áldozatai”: a veszélyeztetettek}

Módszereikkel tulajdonképpen azt lehet mondani, hogy bárkit megkörnyékezhetnek, aki a tudományos kommunikáció szereplöje. Kutató, oktató vagy $\mathrm{PhD}$-hallgató szerzői státuszban és konferenciarésztvevőként, de ugyanilyen eséllyel találnak meg aktív és lelkes asszisztenseket, valamint ápolókat, akik rendszeres látogatói a konferenciáknak. Némi egyszerüsítés árán, de a szakirodalmi példák alapján az alábbi néhány nagyobb csoportba sorolhatóak a potenciálisan veszélyben lévő személyek:

1. azok a szerzők, akiknek nem az angol az anyanyelvük

2. a pályakezdő kutatók, akik számára még ismeretlen a publikálás rendszere; sokszor a behízelgő e-maillel győzik meg őket

3. az, aki pályázati forrásból publikál; a predátorok pontosan tudják, hogy a pályázati pénzek jelentős részét publikálásra és konferencia részvételre kell fordítani

4. a fejlődő országokban élő kutatók

Nem egy cikkben lehet olvasni arról, hogy korábban még mentséget jelentett a tájékozatlanságra és a jóhiszemüségre hivatkozni azoknak a szerzőknek, akik áldozatául estek a csalóknak. Manapság azonban már elég sok fórumon esik szó a predátor kezdeményezésekről ahhoz, hogy valakinek a figyelmét teljesen elkerülje a jelenség. Egyre többen vannak, akik úgy vélekednek, hogy némely szerzők szándékosan hagyják figyelmen kívül a figyelmeztetéseket, és az előre jutás érdekében vállalják cikkük megjelentetését egy-egy predátor kiadványban.

\subsection{Következmények}

A predátor kezdeményezések hatásait mérhetjük az egyének és a tudományos közösségek szintjén is. Előbbi esetében minden kétséget kizáróan az egyik legkomolyabb problémát a szerzők anyagi kizsákmányolása jelenti. Ugyanakkor ne feledkezzünk el arról sem, hogy a szerző a saját hírnevének megítélését is ronthatja azáltal, hogy a neve szóba kerül ilyen szélhámos cselekedetek/tevékenységek/akciók kapcsán. A kezdő kutatók számára is rossz ajánlólevél egy lektorálatlan publikáció kiadása. Arról nem is beszélve, hogy a predátor folyóiratban megjelent cikket már nem lehet tudományos, nívós periodikában publikálni. Végül, de nem utolsó sorban a szakmai bírálat hiánya és 
az áltudományos tézisek terjedése súlyosan károsíthatják az adott tudományterület fejlődését.

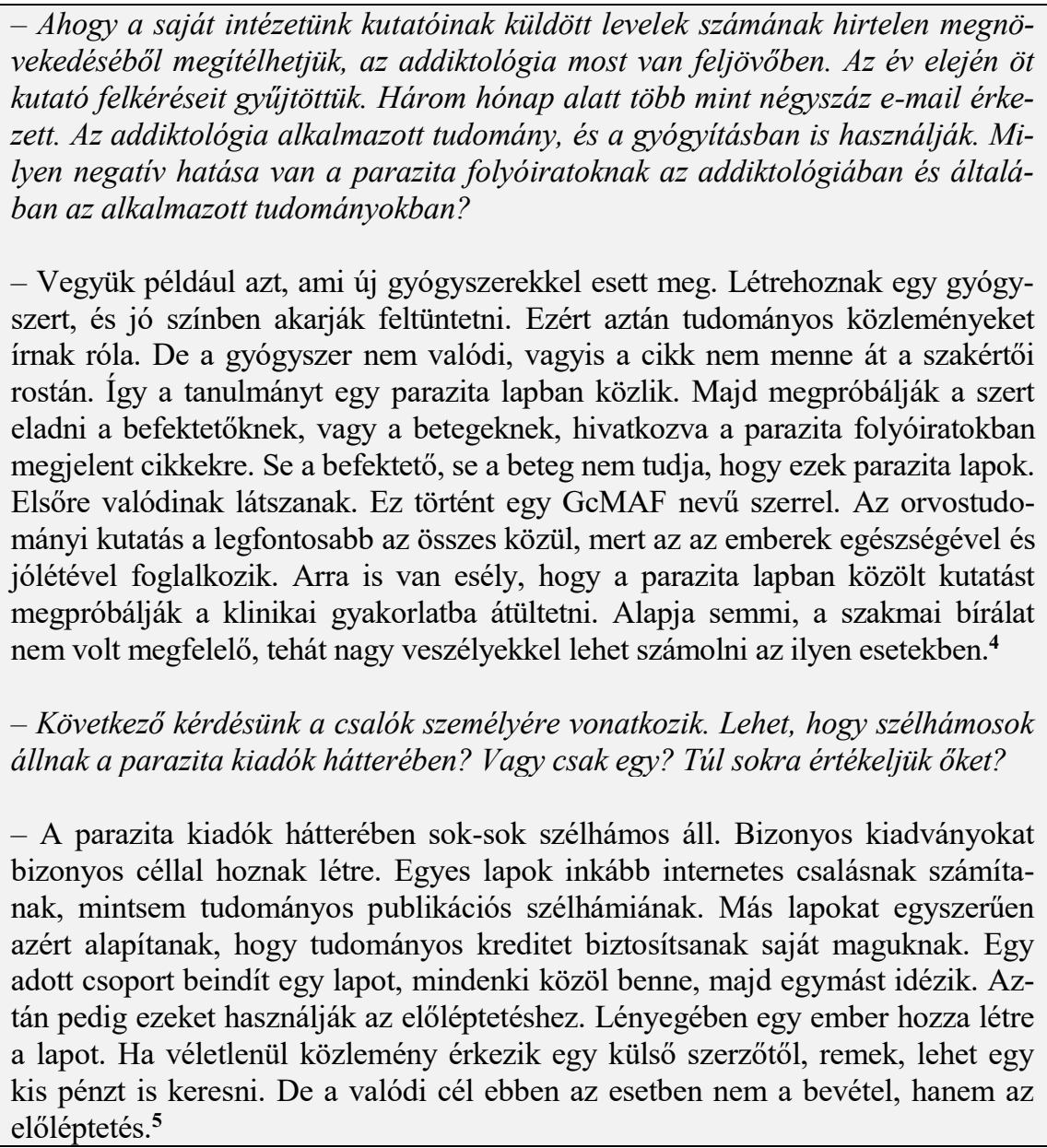

\subsection{Lehetőségek}

Egyetlen módja van megakadályozni azt, hogy a predátor kezdeményezések ne érjenek célba: felkészülten és tudatosan kell kezelnünk a „támadásokat”. Jeffrey Beall feketelistái a kiadókról, folyóiratokról és metrikákról megadják a kezdő lendületet a további ingyenes és fizetős szolgáltatásoknak, amikből néhányat itt is felsorolunk.

4 Hajnal Ward Judit: A tudomány élősködői. Denveri beszélgetés Jeffrey Bealllel. In: Könyv, könyvtár, könyvtáros. vol. 25. iss. 9. pp. 11., pp. 15. 2016. https://bit.ly/3qP2wd0

5

Uott. 


\section{Think.Check.Submit}

A Think.Check.Submit (https://thinkchecksubmit.org/) elnevezésü kampány célja és lényege, hogy a megfelelö kérdések feltevésével és megválaszolásával segítsen a szerzőknek felismerni a predátor kiadókat és folyóiratokat. A kampány második projektje a Thik.Check.Attend https://thinkcheckattend.org/ a konferenciákat állítja a középpontba.

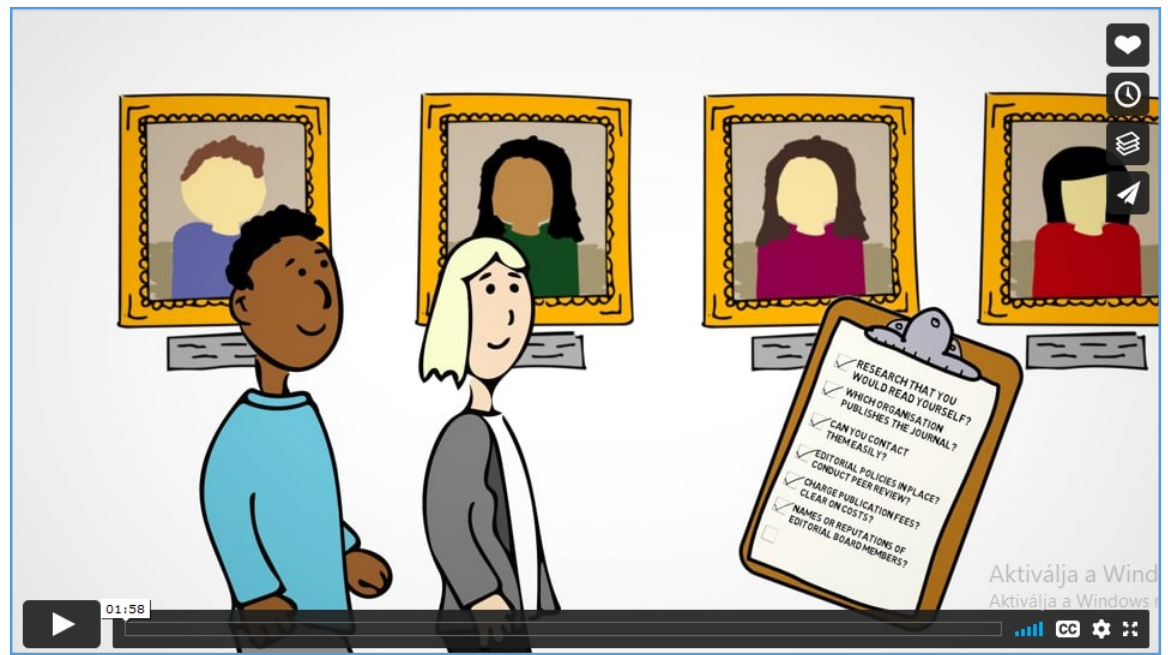

Forrás: https://vimeo.com/151882443

Könyvtári LibGuide-ok

Nagyon sok felsőoktatási könyvtár választotta azt a megoldást, hogy szoftveralkalmazás megvásárlását követően LibGuide-kat hoznak létre a honlapjukon, ahol az open access és a predátor publikálás gyakorlati ismereteire irányuló segédanyagokat állítanak elő és forrásokat gyüjtenek össze. Némelyik honlapon elérhetőek például azok az URL-címek is, melyek Jefferey Beall listáinak archivált változataihoz vezetnek.

A teljesség igénye nélkül emelem ki a New Jersey állami egyetem Rutgers Egyetem Könyvtárának weboldalát http://bit.ly/3eljxTu, ahol a könyvtári szolgáltatás egyik fejlesztő könyvtárosa, Hajnal Ward Judit, az open access és predátor kezdeményezések egyik jeles kutatója, aki egy egész cikket szentelt a platform szolgáltatásai bemutatásának. ${ }^{6}$

6 Hajnal Ward Judit: Vétkesek közt: parazita folyóiratok, kiadók és konferenciák. In: Orvosi Könyvtárak vol. 15. iss. 1. pp. 14-21. 2018. https://bit.ly/38KM2MO 
Ugyanilyen figyelemreméltó a Georg Washington University Himmelfarb Health Sciences Library http://bit.ly/2OZuR2J vagy a University of the Witwatersr and Johannesburg http://bit.ly/38IoSXm honlapjai is.

\section{Más megközelitések}

Nem muszáj mindig „gyanúperrel” élni és eleve negatív oldalról megközelíteni egy-egy folyóiratot. Néhány cikkben remek ötleteket gyüjtöttek össze arra vonatkozóan, hogy mire figyeljünk a folyóiratok kiválasztásakor. (5. és 6. ábra)

\begin{tabular}{|c|c|c|}
\hline Question & What to look for & Red flags \\
\hline $\begin{array}{l}\text { Who is the editor in charge of journal } \\
\text { content? }\end{array}$ & $\begin{array}{l}\text { - A person who has a reputation in the discipline } \\
\text { Direct contact information for the editor is } \\
\text { provided }\end{array}$ & $\begin{array}{l}\text { - You cannot find any evidence of the editor's } \\
\text { standing in the discipline } \\
\text { - There is no contact information provided for } \\
\text { the editor }\end{array}$ \\
\hline $\begin{array}{l}\text { What is the journal's process for } \\
\text { assuring quality of content? }\end{array}$ & $\begin{array}{l}\text { - A clear description of the process for review of } \\
\text { manuscripts prior to publication is stated } \\
\text { - The names and duties of the editorial, advisory, } \\
\text { or review panel members are listed }\end{array}$ & $\begin{array}{l}\text { - A promise of rapid review and publication } \\
\text { (quality reviews take time) } \\
\text { - Mystification of those who are involved in the } \\
\text { review process }\end{array}$ \\
\hline $\begin{array}{l}\text { Does the journal have sound business } \\
\text { and publishing practices? }\end{array}$ & $\begin{array}{l}\text { - The journal and its publisher are members of the } \\
\text { COPE } \\
\text { - The journal is in the INANE/NA\&E Directory of } \\
\text { Nursing Journals } \\
\text { - If the journal shows an impact factor, it is } \\
\text { verifiable in the journal Citation Reports (Web of } \\
\text { Science) }\end{array}$ & $\begin{array}{l}\text { - The publisher/journal is on Beall's list of } \\
\text { predatory publishers at Scholarly Open } \\
\text { Access } \\
\text { - The journal name or other information is } \\
\text { suspiciously like that of another, established } \\
\text { journal } \\
\text { - The journal/publisher solicits manuscript } \\
\text { using excessively complimentary e-mails }\end{array}$ \\
\hline Are there author processing charges? & $\begin{array}{l}\text { - Information about APC, if any, is clear and easily } \\
\text { accessible }\end{array}$ & $\begin{array}{l}\text { - Information about processing charges is not } \\
\text { readily accessible or is unclear }\end{array}$ \\
\hline $\begin{array}{l}\text { Is the journal associated with a } \\
\text { professional organization? }\end{array}$ & $\begin{array}{l}\text { - Association with a known professional } \\
\text { organization is clearly stated }\end{array}$ & $\begin{array}{l}\text { - The association, if any, is completely } \\
\text { unknown to you }\end{array}$ \\
\hline $\begin{array}{l}\text { Is the journal produced by a long- } \\
\text { standing publisher of scientific } \\
\text { literature? }\end{array}$ & $\begin{array}{l}\text { - The name of the publisher is well known. The } \\
\text { publisher produces other journals that you } \\
\text { respect }\end{array}$ & $\begin{array}{l}\text { - You have never heard of the publisher and } \\
\text { are not familiar with the journals they publish }\end{array}$ \\
\hline
\end{tabular}

5. ábra - Carolyn Yucha: Predatory Publishing:

What Authors, Reviewers, and Editors Need to Know.

In: Biological Research for Nursing. Vol. 17. Iss. 1. pp. 5-7. 2015.

BOX 1. VARIAbles to CONSIDER For CHOOSING A JOURNAL

- Focus/Scope

- Indexing status

- Impact factor

- Peer-reviewed

- Affiliation to scientific societies

- Publication frequency

- Publication fees

- Accessibility

- Time to publication/Early online version

6. ábra - Pooja Dewan, Dheeraj Shah:

A Writer's Dilemma: Where to Publish and Where not to? 


\section{Cabells Scholarly Analytics}

Nem mehetünk el szó nélkül amellett sem, hogy természetesen létezik olyan cég, akinek sikerült fizetős szolgáltatást kiépítenie a predátor publikálás jelensége köré. A cég két folyóiratlistát - Blacklist és Whitelist - tesz elérhetővé előfizetés ellenében. Az egyik lista azokat a folyóiratokat gyüjti, amelyekben nem javasolják a szerzők számára a publikálást. Értelemszerűen ez a Blacklist. A Whitelist azokat a folyóiratokat listázza, amelyekben bátran lehet publikálni. A listák ugyan hasonló elveken alapulnak, mint a Jeffrey Beall által gondozott Scholarly Open Access weboldal, mégsem folytatása annak. A Cabells Scholarly Analytics (http://www2.cabells.com/) csak folyóiratokat gyüjt, ellenben Beall-el, aki a periodikák mellett a kiadókról és a félrevezető mérőszámokról is listát vezet. Továbbá igyekeznek objektíven és megkérdőjelezhetetlen kritériumok alapján vizsgálni a folyóiratokat. (2018-ban 65 pontban határozták meg ezeket a feltételeket.) A két listát külön-külön is elő lehet fizetni. A honlapjukon nem tüntetnek fel árlistát, mert ajánlatkérést követően személyre szabottan állítanak ös-sze egy tervezetet. Az összeg megállapításához például az intézménybe beiratkozott hallgatók számát is figyelembe veszik. A cég további fizetős szolgáltatásai közé tartozik a Cabell's Classification Index és az Author Services, amit az Editage céggel közösen biztosítanak. Előbbi a cég saját folyóirat metrikája, ami normalizált citációs értékeket számít. Utóbbi egy tanácsadó szolgáltatás, elsősorban szerzők számára.

\section{Kérdezzünk}

Amennyiben nincsenek segítségükre az ingyenes segédletek, forduljanak a felsőoktatási könyvtárakhoz. Ha a könyvtártól nem akarnak segítséget kérni vagy ök nem tudnak megfelelö tájékoztatást nyújtani végső soron még mindig érdeklődhetnek a kollégáknál azzal kapcsolatban, hogy ők mit tudnak az adott kiadványról és szerkesztőségéről. S az sem rossz döntés, ha a megadott elérhetőségek valamelyikén a kiadó vagy a folyóirat munkatársait felkészült keresztkérdésekkel keressük fel (már ha elérjük őket), majd a válaszok alapján hozunk döntést. 


\subsection{A lecke ismeretlen fogalmainak magyarázatai}

\section{Citescore}

„A folyóiratok önálló mérőszáma. Az idézésék évét megelőző 3 év adatait számolja - általános vélemény, hogy a hároméves időszakasz jobban kifejezi a hivatkozásokat, mint a kétéves. Például: valamely folyóirat 2015-ös CiteScore értéke egyenlő a 2012-ben, 2013-ban és 2014-ben megjelent közleményekre, 2015-ben kapott hivatkozások számának és a 2012, 2013 és 2014-ben megjelent közlemények számának a hányadosával.

A közlések minden formáját (cikkek, levelek, szerkesztői megjegyzések, vélemények, rendezvényi kiadványok stb.) és az ezekre kapott hivatkozásokat elemzi. Tehát a nevezőben és a számlálóban is ugyanazok vannak. A hatásmutató csak a teljes közleményekkel, de a teljes idézettséggel számol.

A CiteScore a Scopus egyik állandó, összehasonlító, átlátható méröszáma, évente adják meg (https://www.scopus.com/sources)."

\section{Clarivate Analytics}

A Clarivate Analytics egy olyan nemzetközi vállalat, ami a tudományos publikáláshoz köthető különféle szolgáltatások előfizetését biztosítja. Termékei között szerepel bibliográfiai adatbázis, hivatkozáskezelő alkalmazás és folyóirat indexelő adatbázis tudománymetriai mérőszámokkal.

\section{$D O A J$}

„A Directory of Open Access Journals (DOAJ) egy nonprofit szervezet, amelynek legfontosabb szolgáltatása az az index, amely több mint 9000 lektorált, tudományos Open Access (OA) folyóirat adatait, illetve az ott megjelent cikkek metaadatait tartalmazza. A DOAJ által jegyzett folyóiratok mindegyike elbíráláson (https://bit.ly/3lgMyHm) esik át, mielött felkerülhetne a listára. A DOAJ, a bevételeit kizárólag támogatásokból szerzi. 2018-ban több mint 100 egyetem és könyvtár, illetve 15 könyvtári konzorcium 26 országból. (https://doaj.org/members) Magyarországról egyelöre egyedül az MTA KIK tagja a szervezetnek."»

7 Bősze Péter: Tudománymérés (2). In: Magyar Orvosi Nyelv vol. 17. iss. 2. 94. pp., 2017.

8 Információk a DOAJ tagságról: http://bit.ly/2OCx2tj 


\section{DOI azonositó}

A DOI (Digital Object Identifier) az elektronikus dokumentumok körében használt egyedi azonosító rendszer, amit a folyóiratok világszerte alkalmaznak a cikkek interneten elérhető elektronikus változatainak megjelölésére.

A DOI olyan rendszer, amely magát az objektumot azonosítja, nem pedig azt a helyet, amelyen ez momentán megtalálható. DOI-s linkek akkor is a dokumentumra mutatnak majd, ha az eredeti helyéről máshová költözött, tehát a hosszú távú megőrzés biztosított.9

\section{EBSCOhost}

Az EBSCO egy nemzetközi adatbázis-szolgáltató cég. Az EBSCOhost pedig annak a keresőfelületnek a neve, amely biztosítja a multidiszciplináris adatbázisokban történő akár egyidejü keresést. Az adatbázisok termékei: e-folyóiratok, e-könyvek, disszertációk, mühelytanulmányok, kormányzati dokumentumok, konferenciaanyagok. Az alábbi adatbázisok találhatóak meg benne:

- Academic Search Complete - multidiszciplináris

- Business Source Premier - közgazdaságtudomány

- EconLit - közgazdaságtudomány

- ERIC - oktatás

- GreenFILE - környezetvédelem

- Library, Information Science \& Technology Abstracts könyvtár- és információtudomány

- MathSciNet - matematika

- MEDLINE - orvostudomány

- Newswires - hírek

- Regional Business News - üzleti hírek

\section{Eigenfactor}

„Folyóiratokat értékelő mértékszám: azt fejezi ki, hogy a folyóirat mennyire hasznos a tudománytársadalomnak; a folyóirat tekintélyére utal. Az idézettség a Journal Citation Reports adatain alapszik.

Figyelembe veszi, hogy mennyire rangos folyóiratban idézték a cikket. Számítás (eigenfactor.org végzi): A vizsgált folyóiratok ötéves, önidézések nélküli idézettségét egyezteti azoknak a folyóira-

9 Digital Object Identifier: https://bit.ly/3rQk5dV; http://bit.ly/3lrWVbu 
toknak a rangjával, amelyekben az idéző cikkek megjelentek. A kapott összértéket 100-nak tekintik. A folyóiratok az idézettségük arányában részesülnek a százból. Például 2006-ban a Nature kapta a legmagasabb értéket: 1,99. Az eigenfactor tehát nem azonos a folyóiratok ötévi összes idézésének a számával, mivel az idéző „minősége” (milyen rangú folyóiratban idézik) és az önidézések figyelmen kívül hagyása módosítja az értéket."10

\section{Impakt faktor}

„Az impakt faktor (IF) a Clarivate Analytics által indexelt folyóiratok tudományos színvonalának fokmérője: megmutatja, hogy adott folyóirat cikkeit más folyóiratok milyen mértékben idézték. Az IF érték a folyóirat hatásmutatója, melyből a tudományos közösség hajlamos az adott cikk (és szerző) minőségére következtetni, helytelenül. Az IF értékek más, a folyóiratok jellemzésére használt mutatókkal együtt évente kerülnek kiszámításra és a Journal Citation Reports-ban (JCR) jelennek meg.” Számítása: „a folyóirat két egymást követő évfolyamában közölt cikkeinek - a cikkek számával arányosított - átlagos idézettsége a rákövetkező 3. tárgyévben."11

\section{ISSN azonositó}

Az ISSN (International Standard Serial Number) az időszaki kiadványok és egyéb folytatódó dokumentumok nemzetközi szabványos azonosítószáma. Numerikus kód, mely a folytatódó dokumentumok egyértelmü azonosítására szolgál. Az ISSN nyolc számjegyből áll, a numerikus kód elemei - a könyveket azonosító ISBN-től eltérően semmiféle jelentést nem hordoznak, csupán azonosító funkciót töltenek be. Az ISSN alkalmazását az ISO 3297 nemzetközi szabvány, illetve annak honosított változata, az MSZ ISO 3297 írja elő. ${ }^{12}$

10 Bősze Péter: Tudománymérés (2). In: Magyar Orvosi Nyelv vol. 17. iss. 2. 94. pp., 2017.

11 Sasvári Péter, Nemeslaki András: Tudományos folyóiratok méltányos rangsorolása az MTA Gazdasági és Jogi Osztályában: mit mutatnak az adatok? In: Magyar Tudomány vol. 178. iss. 1. pp. 80-91. 2017. https://bit.ly/3tlOqBi

12 Gazdag Tiborné (összeállította): Országos Széchényi KönyvtárMagyar ISSN Nemzeti Központ: ISSN útmutató https://bit.ly/38ILW8q 


\section{Indexelő és referáló adatbázisok}

Szaktudományi vagy interdiszciplináris adatbázisok, amelyek az adott tudományterület(ek) legfontosabb forrásait, elsősorban folyóiratokat és az azokban megjelenő publikációkat dolgozza fel. Léteznek olyan adatbázisok is, melyek a folyóiratokon túl/mellett/helyett más dokumentumtípust (könyv, disszertáció stb.) is tartalmaznak. Az adatbázisok mindenekelőtt bibliográfiai adatokat tartalmaznak a dokumentumból készült összefoglalókkal kiegészítve. Ma már ezek az adatbázisok különböző linkmegoldásokkal kapcsolódhatnak a teljes szövegü szolgáltatást nyújtó rendszerekhez. ${ }^{13}$

\section{Journal Citation Reports}

„A Journal Citation Reports (újabb nevén: Journal and Highly Cited Data, JHCD) a világ vezető tudományos folyóiratainak hivatkozási adatait gyüjti. A tudománymetriai mérőszámok közül megtalálható benne a folyóiratok impakt faktora (IF) is. Az adatbázis 1997-től tartalmaz adatokat."14

\section{Scimago Journal Rankings (SJR)}

„Az SJR komplex mutató, amely az idézések számát súlyozza az idéző folyóiratok idézettségével (,presztízsmutató”). Ez a relatív mutató azt fejezi ki, hogy a vizsgált folyóirat az adott szakterületi kategória kiadványainak mekkora hányadát előzi meg SJR tekintetében.

Módszertanilag ez a közlemények minőségi osztályokba (kvartilisokba) sorolásával történik a közlő folyóiratok saját szakterületükön elfoglalt pozíciói, rangjai alapján:

- Q1: Kiváló folyóiratok, amelyek a szakterületi SJR- (mérőszámalapú) rangsor felső 25\%-ához tartoznak.

- Q2: Jó folyóiratok, amelyek a szakterületi SJR-rangsor 5075\%-a közé tartoznak.

- Q3: Közepes folyóiratok, amelyek a szakterületi SJR-rangsor 25-50\%-a közé tartoznak.

- Q4: Gyenge folyóiratok, amelyek a szakterületi SJR-rangsor alsó $25 \%$-ához tartoznak.

13 Osorio, L. Nestor - Otieno, Andrew W.: A survey of manufacturing engineering databases=Klein Ágnes (ford.) E-tmt - Áttekintés a gyártástechnológiai adatbázisokról. In: Tudományos és Müszaki Tájékoztatás vol. 56. iss. 2. 2009. http://bit.ly/2OAsIuH

$14 \mathrm{http}: / /$ bit.ly/3qLzRpb 
Egy folyóiratot több szakterületen is jegyezhetnek, és elöfordulhat az, hogy az egyik szakterületen „kiváló” besorolást kap a szóban forgó folyóirat, míg a másik szakterületen csak a „közepes” vagy akár a „gyenge” kategóriába kerül."15

\section{Scopus}

„A Scopus az Elsevier kiadó hivatkozáskereső bibliográfiai adatbázisa. A naponta frissülő adatbázis amellett, hogy absztraktok formájában feldolgozza minden tudományterület legfontosabb szakirodalmi forrásait, leginkább tudománymetriai mérések elvégzésére és a szerzői hivatkozások feltárására alkalmas. Az adatbázisban található absztraktokhoz sok esetben tartozik teljes szövegü cikk is, ami a ScienceDirect oldalán olvasható."16

\subsection{Felhasznált irodalom}

1. Hajnal Ward Judit: Parazita lapok - tudomány élösködői. In: Könyv, könyv-tár, könyvtáros. vol. 25. iss. 9. pp. 17-25. 2016. https://bit.ly/3qPdWgL

2. Hajnal Ward Judit: A tudomány élösködői. Denveri beszélgetés Jeffrey Beall-lel. In: Könyv, könyvtár, könyvtáros. vol. 25. iss. 9. pp. 916. 2016. https://bit.ly/3qP2wd0

3. Matti Myllykoski: Open access in the eyes of its sharpest critic: an interview of Jeffrey Beall. In: Journal of EAHIL vol. 12. iss. 2. pp. 20-24. 2016. https://bit.ly/38GI73B

4. Hajnal Ward Judit: A tudomány élősködői. Denveri beszélgetés Jeffrey Beall-lel. In: Könyv, könyvtár, könyvtáros. vol. 25. iss. 9. pp. 11., pp. 15. 2016. https://bit.ly/3qP2wd0

5. Uott.

6. Hajnal Ward Judit: Vétkesek közt: parazita folyóiratok, kiadók és konferenci-ák. In: Orvosi Könyvtárak vol. 15. iss. 1. pp. 14-21. 2018. https://bit.ly/38KM2MO

7. Bősze Péter: Tudománymérés (2). In: Magyar Orvosi Nyelv vol. 17. iss. 2. 94. pp., 2017.

8. Információk a DOAJ tagságról: http://bit.ly/2OCx2tj

9. Digital Object Identifier: https://bit.ly/3rQk5dV; http://bit.ly/3lrWVbu

15 Sasvári Péter, Nemeslaki András: Tudományos folyóiratok méltányos rangsorolása az MTA Gazdasági és Jogi Osztályában: mit mutatnak az adatok? In: Magyar Tudomány vol. 178. iss. 1. pp. 80-91. 2017. https://bit.ly/3tlOqBi

$16 \mathrm{http}: / /$ bit.ly/38F3TEz 
10. Bősze Péter: Tudománymérés (2). In: Magyar Orvosi Nyelv vol. 17. iss. 2. 94. pp., 2017.

11. Sasvári Péter, Nemeslaki András: Tudományos folyóiratok méltányos rangso-rolása az MTA Gazdasági és Jogi Osztályában: mit mutatnak az adatok? In: Magyar Tudomány vol. 178. iss. 1. pp. 80-91. 2017. https://bit.ly/3tlOqBi

12. Gazdag Tiborné (összeállította): Országos Széchényi KönyvtárMagyar ISSN Nemzeti Központ: ISSN útmutató https://bit.ly/38ILW8q

13. Osorio, L. Nestor - Otieno, Andrew W.: A survey of manufacturing engineering databases=Klein Ágnes (ford.) E-tmt - Áttekintés a gyártástechnológiai adat-bázisokról. In: Tudományos és Müszaki Tájékoztatás vol. 56. iss. 2. 2009. http://bit.ly/2OAsIuH

14. http://bit.ly/3qLzRpb

15. Sasvári Péter, Nemeslaki András: Tudományos folyóiratok méltányos rangso-rolása az MTA Gazdasági és Jogi Osztályában: mit mutatnak az adatok? In: Magyar Tudomány vol. 178. iss. 1. pp. 80-91. 2017. https://bit.ly/3tlOqBi

16. http://bit.ly/38F3TEz

\subsection{2. Összefoglalás}

A predátor kezdeményezések mindig valamilyen hátsó szándékkal alakulnak. Az anyagi érdekek mentén történő szerveződés mellett sokszor egy tudományosan megkérdőjelezhető kutatási eredmény jobb színben történő feltüntetése a cél. A csalók általában spam üzeneteken keresztül, behízelgő hangvételü megkeresésekkel érik utol a gyanútlan szerzőket. Az indexelő adtabázisokban és könyvtári katalógusokban nincs nyoma a létezésüknek. A csábító ígéreteik ellenére tevékenységüknek nincs tudományos jellege. A szerkesztő bizottságukat gyakran kitalált tagok alkotják vagy engedély nélkül tüntetik fel a nemzetközileg elismert szerzőket. Annak érdekében, hogy minél meggyőzőbbek legyenek hamis teljesítménymutatókat is kitalálnak. Jelenlétük negatív hatással van a tudományos közösségek és a tudományterületek egészére. Szerencsére kiterjedt szakirodalma van a témának és egyre több ingyenes valamint fizetős szolgáltatás létezik, melyek segítségével a szerzők elkerülhetik a munkásságuk megítélését fenyegető predátor kezdeményezéseket. 


\subsection{3. Önellenőrző kérdések}

Milyen predátor kezdeményezéseket ismer?

Predátor folyóiratkiadás, predátor konferencia, megtévesztő mutatószámok. (Lásd a „Predátor kezdeményezések” címü fejezetet!

Sorolja fel a predátor folyóirat-kiadás föbb ismertetőjegyeit

(A válaszok a lecke „A predátor folyóirat-kiadás jellemzői és árulkodó jelei” címü alfejezetében találhatók.)

Milyen módszerekkel lehet elkerülni a predátor kezdeményezéseket?

(A válaszok a lecke „Lehetőségek” című alfejezetében találhatók.) 


\section{A SZAKMAI LEKTORÁLÁS KIHÍVÁSAI}

\section{Bevezetö gondolatok}

A tananyag válogatott szakirodalom feldolgozásával mutatja be a szakmai lektorálás legfontosabb ismérveit. A szakmai lektorálás a tudományos kommunikáció fontos részét képzi, a hazai szakirodalomban mégis kevés átfogó elemzés foglalkozik vele. A lektorálás folyamatára vonatkozó szabályozás folyóiratonként eltérő, a szerzők erre vonatkozó ismereteiket általában tapasztalati úton szerzik meg. A leckében összegyüjtöttük a lektorálás általános jellemzőit, kitérünk arra, hogy milyen szakaszai és típusai vannak a lektorálásnak, valamint milyen problémák húzódnak meg a változtatása iránti igény megfogalmazásában.

\section{Célok, megszerezhetö kompetenciák}

A tananyag célja, hogy átfogó és általános érvényü ismereteket adjon át a hallgatóknak, melyek megtanulását követően az ismeretlen publikációs környezetben is képes boldogulni. A témához kapcsolódó összegyüjtött alapfogalmak hasznos útmutatásul szolgálnak a publikációs tevékenység során. A lecke mindenekelőtt a résztvevő kritikai gondolkodásmódját fejleszti.

Szükséges eszközök, források

Jól müködő asztali vagy hordozható számítógép és internetkapcsolat.

\section{Feldolgozási idö}

- 90 perc

\section{Témakörök}

- Bevezetés

- Általános tudnivalók a szakmai lektorálásról, a lektorálás gyakorlata

- A lektorálással szemben megfogalmazott kritikák

- A lecke ismeretlen fogalmainak magyarázata 


\section{Irodalmak}

- Alice Meadows: Journals Peer Review: Past, Present, Future. In: Scholarly Kitchen. Sep 14, 2017. https://bit.ly/3eF5fmU

- Debra Dunn: The value and Process of Peer Review. In: AORN Journal. First published: 29 May 2018 https://bit.ly/3lkUMOB

- Fenyvesi Tamás: Kettős vak lektorálás. In: Orvosi Hetilap vol. 143. iss. 5. pp. 245-248. 2002. https://bit.ly/3bR3ocG

- Hajnal Ward Judit: Ki szavatol a ...? Helyzetjelentés a tudományos lektorálás állásáról. In: Könyvtári Figyelő vol. 58. iss. 4. pp. 713-726. 2012. https://bit.ly/3cwkbAZ

- Lisa I. Iezzoni: Explicit Disability Bias in Peer Review. In: Medical Care vol. 56. iss. 4. pp. 277-278. 2018.

- Mark Ware: Peer review: Recent Experience and Future Directions. In: New Review of Information Networking vol. 16. iss. 1. pp. 23-53. 2011. https://bit.ly/3rRrPwe

- Michael Jubb: Peer review: The current landscape and future trends. In: The Association of Learned \& Professional Society Publisher vol. 29. pp. 13-21. 2016. https://bit.ly/3eIguLi

\subsection{Bevezetés}

A folyóirat-kiadás és az Open Access Mozgalom témakörében feldolgozott tananyagok rávilágítottak arra, hogy a tudományos publikálás nehezen megújuló rendszer. A tudományos közösség tagjainak jelentős része még ma is ragaszkodik a hagyományokhoz. A publikálásra vonatkozó új eszmék azonban nem csak a kiadás módjának változására törekszenek. A szerzők egyre hangsúlyosabban kérdőjelezik meg a beküldött kéziratokra vonatkozó szakmai bírálatok, vagyis a lektorálás rendszerét is. Éppen ezért érdemes megismerkedünk a jelenleg érvényben lévő és az újfajta lektorálási gyakorlatokkal.

\section{2. Általános tudnivalók a szakmai lektorálásról, a lektorálás gyakorlata}

\section{A lektorálás folyamata}

Egy publikáció megjelentetése hosszú folyamat, ami tulajdonképpen a kutatási kérdés publikálási szándékának megfogalmazódásával kezdődik. A lektorálás ott kapcsolódik be az eljárásba, amikor az elkészült kéziratot a szerző beküldi az általa kiválasztott folyóirat szer- 
kesztőségébe. Miután a szerző beküldte a kéziratát, a szerkesztőség tagjai különböző szempontok alapján döntenek arról, hogy tovább küldik-e lektorálásra. A kézirattal szemben támasztott általános kritériumok a következők: megfelel-e a folyóirat profiljának és eleget tesz-e a folyóirat által meghatározott formai követelményeknek - ez alatt értjük a megfelelően formázott szöveget és a helyesen összeállított hivatkozásokat, valamint irodalomjegyzéket. Már ezen a szinten magas lehet az elutasított kéziratok száma.

A cikk elfogadását követően értesítést kap a szerző, hogy tanulmánya a lektorálás fázisába került. A folyóirat szerkesztősége egy listából választja ki a két lektort, akik aztán egymástól függetlenül hoznak döntést: javasolják publikálásra vagy visszautasítják az írást. A lektorálásra elfogadott cikket további javításokkal és megjegyzésekkel látják el, amiket a szerzővel is megosztanak, aki jobbára ezen kritikai észrevételek mentén módosítja a cikkét. A cikk abban az esetben kerül publikálásra, ha azt a lektorok egyöntetüen jóváhagyják.

A bírálók feladata a tanulmányok eredetiségének megállapítása és szakmai véleményezése. Ennek része a kutatásmódszertan ellenőrzése, a logikai hibák felismerése, szükség szerint az illusztrációk (képek, táblázatok, diagramok) javítására tett javaslatok a könnyebb értelmezhetőség érdekében, valamint az irodalomjegyzék és a hivatkozások vizsgálata (kurrens irodalmat használ-e a szerzö, a szövegben ténylegesen hivatkozza-e egy cikk tartalmát vagy csak az irodalomjegyzékben tünteti fel, felismerhető ellentmondások).

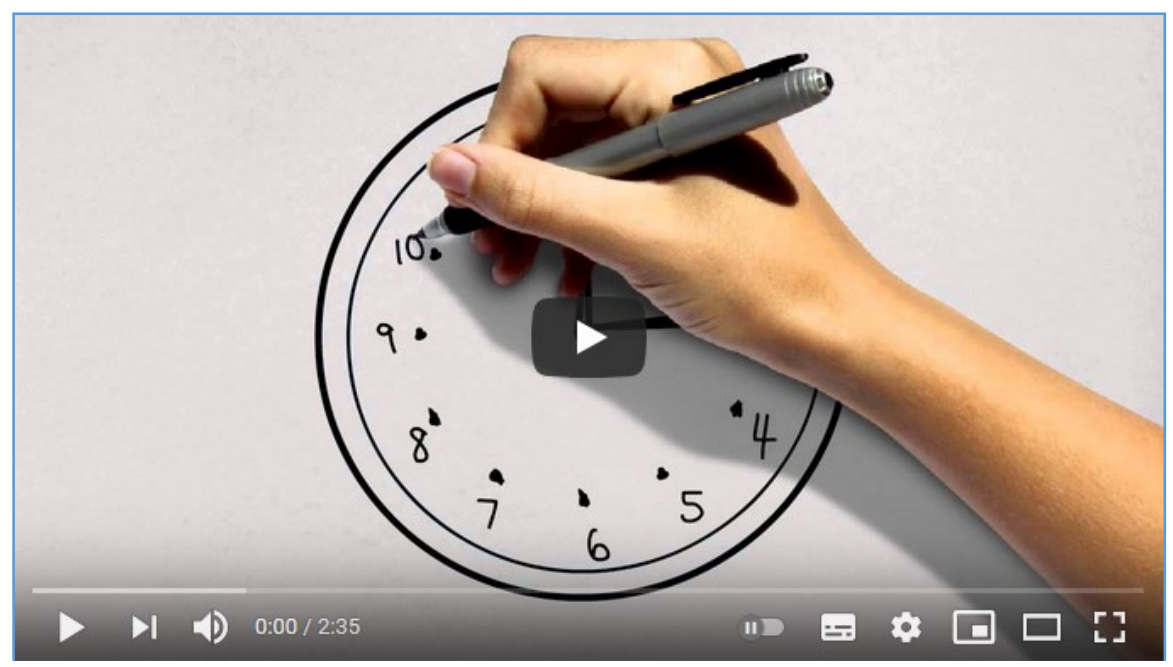

A lektorálás folyamata — Forrás: https://youtu.be/Jc6wr9gYbyk 
A valóságban azonban több tényező is megnehezíti a lektorok feladatát. Az egyik ilyen, hogy a lektori elfoglaltság nem jelent teljes munkaidős állást. A szakmai lektorok általában maguk is az adott tudományterület elismert szakemberei, felsőoktatási vagy kutató intézmények munkatársai fóállásban. Szerzőtársaikhoz hasonlóan ők is aktív kutatói munkát végeznek. Egy másik jelentős szempont, hogy a bírálók nem aktív résztvevői vagy megfigyelői a munkának, úgy próbálják kiszürni a súlyos szakmai tévedéseket, hogy csak a kutatás egyfajta összegzését vizsgálják. Szintén létező problémaként említhetjük a jelentkezők hiányát. Ehhez érdekes adatként szolgálhat, hogy 2012ben a kínai kutatók a tudományos folyóiratcikkek kibocsátásának 18\%-ért voltak felelősek; lektori munkát azonban mindössze $6 \%$ vállalt. A legfontosabb pedig az emberi tényező, hiszen senkitől nem várható el, hogy hiba nélkül dolgozzon. ${ }^{1}$

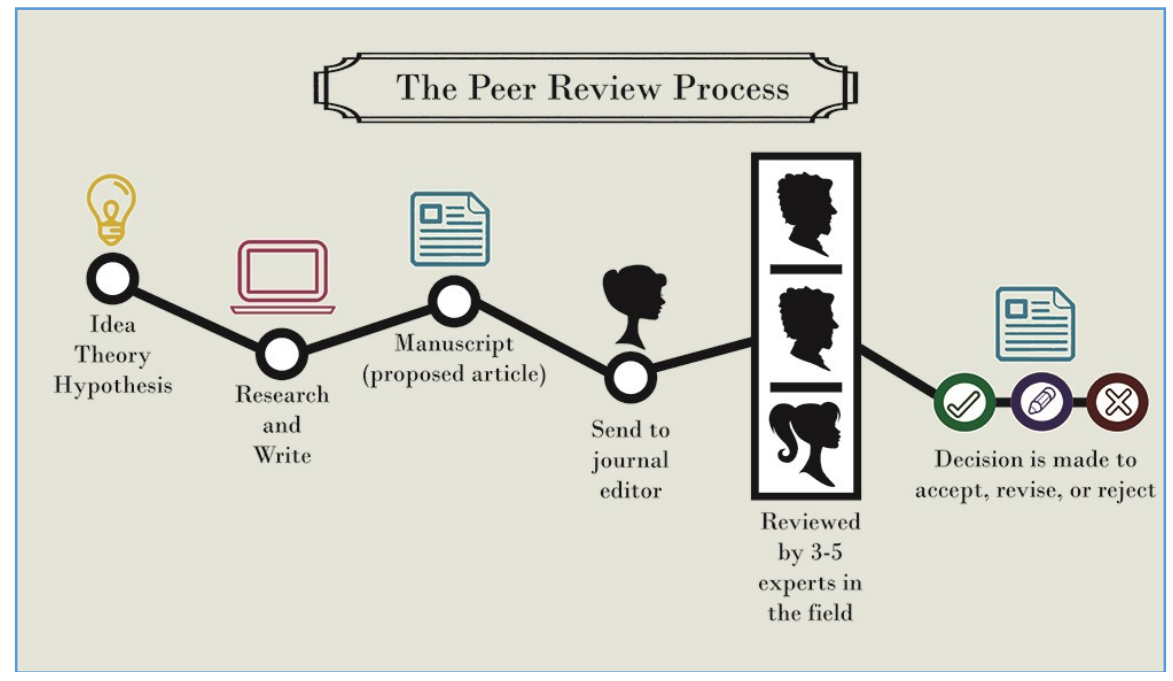

„A Royal Society of London folyóirata, a Philosophical Transactions már 1665ben megkülönböztette a lektorált és nem lektorált közleményeket, és alapvetönek tartotta, hogy legyen közlés elött független értékelés. Ez már a kezdetekkor is számos furcsa tévedést eredményezett. Jenner kéziratát a himlő elleni vaccinatióról ez a maga idejében legnagyobb presztízsü folyóirat elutasította (1796), a szakértő szerint kevés volt a bizonyíték. így, mint azt Lock, a BMJ 1975-1991

1 Hajnal Ward Judit: Ki szavatol a ...? Helyzetjelentés a tudományos lektorálás állásáról. In: Könyvtári Figyelő vol. 58. iss. 4. pp. 716-717. 2012. https://bit.ly/3cwkbAZ; Bodnár János Kristóf, Gajdos Ágoston, Kakuk Péter: A Hvang-botrány következményei és tanulságai. In: Magyar Tudomány vol. 176. iss. 8. pp. 908. 2015. https://bit.ly/3vqXSoW; Michael Jubb: Peer review: The current landscape and future trends. In: The Association of Learned \& Professional Society Publisher vol. 29. pp. 15. 2016. https://bit.ly/3eIguLi 
közötti főszerkesztöje a lektorálásról írt kiváló könyvében leírja, a Royal Society elhatárolta magát a XVIII. század legnagyobb orvosi felfedezésétől, tette ezt annak ellenére, hogy Jenner a jeles társaság tagja volt. Jenner eredményeit magánkiadásban jelentette meg."’2 Krebs közleménye a citromsavciklusról, McClintock kutatása a mobil genetikai elemekről, valamint Berson és Yalow inzulinmeghatározásra kidolgozott radioimmunoassay eljárása mind olyan Nobel-díjas felfedezések, melyeket lektori véleményezés alapján elutasítottak a folyóirat

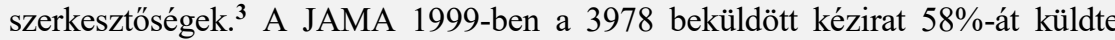
tovább lektoroknak, 38\%-ot még a lektori értékelés elött elutasított a folyóirat szerkesztőség. A felkérésre írt szerkesztőségi cikkeket közvetlenül elfogadta - ez $4 \%$-ot jelentett. A nem felkérésre beküldött kéziratok $9 \%$-át közölték. ${ }^{4}$

\section{A lektorálási gyakorlatok típusai}

\section{II.1. Hagyományos lektorálási gyakorlat}

\section{II.1.1. Zárt lektorálás}

Zárt szakmai bírálati rendszernek nevezzük azt, amikor a szerző és a lektor közül valamelyik fél vagy mindkettő kiléte teljesen titkos marad a kézirat bírálati ideje alatt. A zárt lektorálási rendszernek két fajtáját különböztetjük meg: az egyiket angolul single blind-nak, a másikat double blind-nak nevezzük.

\section{II.1.1.a. Single blind peer review}

Angolul „single-blind”-nak nevezzük azt a lektorálási rendszert, amelyben az egyik fél kiléte ismeretlen. Ennek leggyakoribb megvalósulása, amikor a lektor személye titkos a szerző elött, de a lektor ismeri a szerzőt. A kutatók első számú félelme természetesen az, hogy a lektorok anonimitása felhatalmazást ad a szokatlanul kedves vagy kritikus véleményezésre. A tapasztalatok és a vizsgálatok azt mutatják, hogy a nevüket felvállaló lektorok értékelései udvariasak és

2 Fenyvesi Tamás: Kettős vak lektorálás. In: Orvosi Hetilap vol. 143. iss. 5. pp. 245. 2002. https://bit.ly/3bR3ocG

3 Fenyvesi Tamás: Kettős vak lektorálás. In: Orvosi Hetilap vol. 143. iss. 5. pp. 245., pp. 247. 2002. https://bit.ly/3bR3ocG; Hajnal Ward Judit: Ki szavatol a ...? Helyzetjelentés a tudományos lektorálás állásáról. In: Könyvtári Figyelő vol. 58. iss. 4. pp. 719-720., pp. 716. 2012. https://bit.ly/3cwkbAZ

4 Fenyvesi Tamás: Kettős vak lektorálás. In: Orvosi Hetilap vol. 143. iss. 5. pp. 245., pp. 247. 2002. https://bit.ly/3bR3ocG; Hajnal Ward Judit: Ki szavatol a ...? Helyzetjelentés a tudományos lektorálás állásáról. In: Könyvtári Figyelő vol. 58. iss. 4. pp. 719-720., pp. 716. 2012. https://bit.ly/3cwkbAZ 
konstruktívak, a cikkeket nagyobb arányban javasolják megjelenésére, mint azok a kollégáik, akik anonim módon lektorálnak. ${ }^{5}$

A modell fordítva is müködőképes. Unmasking-nak nevezik azt az eljárást, amiben a szerző előtt felfedik a lektor személyét. Ilyen esetekben viszont azt kérik a szerzőktől, hogy távolítsanak el minden utalást a szövegből (név, cím, e-mail cím, intézményi affiliáció), amivel azonosítani lehet öket. Ennek célja, hogy a kiküszöböljék a korábban említett pozitív vagy negatív irányú bírálói elfogultságokat. Azonban bizonyos szakterületeken, ahol - akár nemzetközi szinten is - kisebb kutatói közösségekről beszélhetünk, nehéz betartani a titoktartást. Erre konkrét példa, hogy az orvos-biológia területén a lektorok 23-42 százalékos arányban azonosítani tudták a szerzőket. ${ }^{6}$

Más vizsgálatok eredményei arra hívják fel a figyelmet, hogy a szerzők adatainak titokban tartására törekvő kezdeményezések 40\%ban megbuktak, ugyanis a szakmai bírálók annyira ismerik a szakterületük vezető kutatóit, a kollégáikat, hogy gyakran a kézirat témájáról és az írás stílusáról is felismerik őket. ${ }^{7}$

\section{II.1.1.b. Double blind peer review}

A nemzetközi szakirodalomban használt double-blind peer review-t magyarul kettős vak lektorálásnak nevezik. Ebben az esetben a szerkesztőbizottság nem fedi fel a szakmai bírálók és a szerzők nevét egyik fél előtt sem. Vagyis a bírálók a szerzők ismerete nélkül ellenőrzik a beküldött kéziratokat, a szerzők pedig nem tudják, hogy ki lektorálja a szövegeiket. Egyre gyakoribb, hogy a folyóiratszerkesztőségek ezt a megoldást preferálják. A Nature Publishing Group 2015 márciusa óta engedélyezi a szerzőknek, hogy ezt a lektorálási típust válasszák. ${ }^{8}$

5 Hajnal Ward Judit: Ki szavatol a ...? Helyzetjelentés a tudományos lektorálás állásáról. In: Könyvtári Figyelő vol. 58. iss. 4. pp. 719-720., pp. 721. 2012. https://bit.ly/3cwkbAZ

6 Uott.

7 Fenyvesi Tamás: Kettős vak lektorálás. In: Orvosi Hetilap vol. 143. iss. 5. pp. 247. 2002. https://bit.ly/3bR3ocG; Debra Dunn: The value and Process of Peer Review. In: AORN Journal. First published: 29 May 2018 https://bit.ly/3lkUMOB

8 Michael Jubb: Peer review: The current landscape and future trends. In: The Association of Learned \& Professional Society Publisher vol. 29. pp. 16. 2016. https://bit.ly/3eIguLi 
„A lektorálás minőségét a titkosság nem biztos, hogy befolyásolja. A szerzők beleegyezésével a BMJ-ben már elfogadott kéziratba utólag 8 hibát helyeztek el a tervezésbe, az analízisbe vagy az interpretációba. Ezeket a megváltoztatott kéziratokat 420 lektornak küldték el. Négy csoport tagjai tudták, hogy egy a lektorálás minőségét vizsgáló kutatás résztvevői, az ötödik csoport a szokásos lektorálási felkérést kapta, nem tudták, hogy egy vizsgálat résztvevői. A kéziratokba szándékosan elrejtett hibák felderítését a szerző vagy a lektor titkossága nem befolyásolta."9 A PeerJ 2014-es felmérése szerint a publikálásra javasolt cikkek esetében a lektorok $50 \%$-a vállalja a nevét, viszont csak $14 \%$ vállalja a nevének nyilvánossá tételét a cikk elutasítását követően. ${ }^{\mathbf{1 0}}$

\section{II.2. Új típusú lektorálási gyakorlatok}

\section{II.2.1. Nyilt lektorálás}

Angolul open peer review-nak nevezik a nyílt lektorálás folyamatát, ahol a szerzők és a lektorok személye nyilvános, a bírálás folyamata átlátható. A nyílt lektorálás az elszámoltathatóságot és az udvariasságot akarja ösztönözni. A fokozottabb elszámoltathatóság célja, hogy alaposabb véleményezésre motiválja a lektorokat. ${ }^{11}$

A leggyakrabban megfogalmazott ellenérvek szerint ez a módszer kevésbé őszinte, és ezért kevésbé merik leírni a kritikai észrevételeiket. Egy másik probléma, hogy a nyitottság neheztelést és ellenségeskedést okozhat a kollégák között.

Annak ellenére, hogy továbbra sem ez a leggyakoribb formája a szerkesztőséghez beküldött kéziratok értékelésének, számos kiadó már régóta alkalmazza ezt a lektorálási technikát, és több folyóiratnál ma is müködő és szilárd alapokon álló rendszerröl beszélhetünk. Ilyen például a British Medical Jounal (BMJ), a Biomed Central, az Elsevier kiadó egyes folyóiratai és a PLoS. ${ }^{12}$

„Az úgynevezett nyílt lektorálásnak több változata lehetséges, a közös vonás a lektor személyének nyílt feltárása és az elbírálási folyamat átáthatósága. A négy legrangosabb orvostudományi folyóirat egyike, a BMJ 1999-ben vezette be a nyílt lektorálási gyakorlatot. Minden lektor nevét adja és aláírja az általa készített bírá-

9 Fenyvesi Tamás: Kettős vak lektorálás. In: Orvosi Hetilap vol. 143. iss. 5. pp. 248. 2002. https://bit.ly/3bR3ocG

10 Michael Jubb: Peer review: The current landscape and future trends. In: The Association of Learned \& Professional Society Publisher vol. 29. pp. 16. 2016. https://bit.ly/3eIguLi

11 Debra Dunn: The value and Process of Peer Review. In: AORN Journal. First published: 29 May $2018 \mathrm{https} / / / \mathrm{bit} . l y / 31 \mathrm{kUMOB}$

12 Fenyvesi Tamás: Kettős vak lektorálás. In: Orvosi Hetilap vol. 143. iss. 5. pp. 247-248. 2002. https://bit.ly/3bR3ocG 
latot. Az igazsághoz tartozik az is, hogy a beküldött kéziratok fele kihullik az első, szerkesztőségi rostán, és csak a másik fele kerül ki lektorálásra egy vagy két bírálóhoz, akik munkájukért ötven font honoráriumban részesülnek. A cikk elfogadásáról vagy elutasításáról egy alkalmi szerkesztőbizottság hozza meg a végső döntést, amelynek tagjai az adott cikkhez rendelt szerkesztőn kívül egy külső tanácsadó és egy statisztikus is. A bizottság tagjai alaposan átolvassák és megvitatják a tanulmányt a szokásos szempontok alapján (a téma jelentősége, eredetisége és a tanulmány minősége). Az írás benyújtásától számítva 8-10 héten belül születik meg a döntés. Ha változtatásra van szükség, a szerzőnek négy hetet adnak a módosított kézirat benyújtására. Végezetül álljon itt egy számadat az eredeti tanulmányok elfogadási arányára, ami mindössze hét százalék (Suls és Martin, 2009).

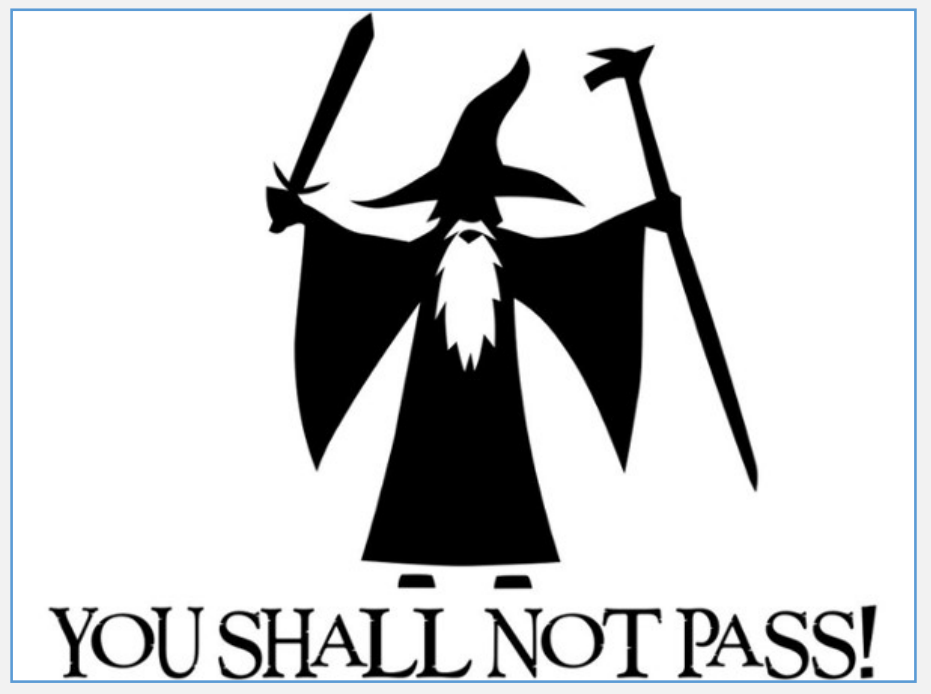

A nyílt lektorálás egy másik példája a PLoS (Public Library of Science) gyakorlata. A PLoS az egyik legjelentősebb propagálója a tudományos eredményekhez való nyílt hozzáférésnek. Az általuk publikált folyóiratok többé-kevésbé ugyanazt a lektorálási gyakorlatot követik. A beérkezett tanulmányt elsőként egy belső szakmai lektor, vagyis a szerkesztőbizottság valamelyik tagja olvassa át, akinek feladata mindössze a kutatás vagy kísérlet lefolytatása és elemzése során esetleg elkövetett durva hibák felfedezése. A tanulmány fontosságáról szóló döntést ezen a ponton kifejezetten ellenzik. Ha a cikk átmegy az első szűrőn, akkor közzéteszik a PLoS oldalán, ahol az olvasók az egyes részeket kommentálhatják, illetve a teljes írást minősíthetik. Mindezt a szerkesztőbizottság figyelemmel kíséri az idézettséggel együtt, majd a jó kritikát kapott és gyakran idézett cikkeket kiemelten ajánlják az olvasói kör figyelmébe. A lektorálási folyamat ezen változatának legnagyobb pozitívuma, hogy szinte azonnal visszajelzést kap a szerző a tanulmányáról, mégpedig meglehetősen széles körből, és ebből az is kiderül, hogy az egyes cikkek fogadtatása nem feltétlenül áll arányban a folyóirat tekintélyével (Suls és Martin, 2009)."

13 Hajnal Ward Judit: Ki szavatol a ...? Helyzetjelentés a tudományos lektorálás állásáról. In: Könyvtári Figyelö vol. 58. iss. 4. pp. 722. 2012. https://bit.ly/3cwkbAZ 


\section{II.2.2. Collaborative peer review}

Akad néhány folyóirat, ahol elkezdtek kísérletezni a collaborative peer review-val. Ennek a típusnak a jellemzője, hogy kettő vagy több lektor dolgozik a kézirat értékelésén. Az ötleteiket és véleményeiket előbb egymással osztják meg, majd egy közösen megfogalmazott álláspontot küldenek el a levelező szerző(k)nek. A lektorok a végső kézirat megjelentetéséig együtt dolgoznak a szerzővel. Elönye, hogy konstruktív, és kevésbé korlátozó. Hátránya, hogy elmosódhatnak a szerepkörök közötti határok és a lektorok átvehetik a szerzők szerepét. ${ }^{14}$

\section{II.2.3. Transferable peer review}

Előfordulhat olyan eset, hogy a kiválasztott folyóirat valamilyen okból nem tudja befogadni a kéziratot és visszautasítja. A Neuroscience Peer Review Consortium kezdeményezésében több mint 60 folyóirat vesz részt, amelyek vállalják, hogy a korábban a konzorciumban résztvevő folyóirat által elutasított kéziratot újra ellenőrzik. Az angol nyelvü szakirodalomban többféleképpen hivatkoznak erre a bírálói típusra: transferable, cascading, portable review. ${ }^{15}$

\section{II.2.4. Post publication peer review}

Ez a bírálói folyamat a digitális kommunikációs eszközök fejlődésének, az online folyóiratok és a közösségi média terjedésének köszönhetően alakult ki. A publikáció kéziratát online, elektronikus változatban tölti fel a folyóirat szerkesztőbizottsága vagy a szerző a megfelelő online platformokra, és engedélyezik az olvasóknak, hogy megjegyzéseket írjanak hozzá. Ez történhet a cikk hagyományos szakmai bírálata előtt vagy után is. Tulajdonképpen vég nélküli folyamatról beszélünk, mert a publikáció véleményezése a közzététele után is folytatódik. Előnye, hogy a cikkek javítására tett javaslatok tükrözik a tudás változó természetét és lehetővé teszik a publikált anyag frissítését, javítását, módosítását. Alkalmas módszer lehet a hagyományos lektorálás kiegészítésére. ${ }^{16}$

14 Debra Dunn: The value and Process of Peer Review. In: AORN Journal. First published: 29 May $2018 \mathrm{https} / / / \mathrm{bit} . l \mathrm{ly} / 3 \mathrm{kUMOB}$

15 Debra Dunn: The value and Process of Peer Review. In: AORN Journal. First published: 29 May 2018 https://bit.ly/3lkUMOB; Michael Jubb: Peer review: The current landscape and future trends. In: The Association of Learned \& Professional Society Publisher vol. 29. pp. 17. 2016. https://bit.ly/3eIguLi

16 Debra Dunn: The value and Process of Peer Review. In: AORN Journal. First published: 29 May $2018 \mathrm{https} / / / \mathrm{bit} .1 \mathrm{y} / 3 \mathrm{kUMOB}$ 
A szerzők általános álláspontja mégis az, hogy a cikkek közzététele után nem szívesen írnak hozzá megjegyzéseket. Egyrészt elfoglaltságra hivatkoznak, másrészt arra, hogy nem kívánnak konfrontálódni a kollégákkal, harmadrészt - ami talán a legnyomósabb érv -, hogy jobban szeretik a helyreigazításaikat és a hozzászólásaikat tudományos publikációként megjelentetni és elismertetni. ${ }^{17}$

\section{II.2.5. Szakmai moderálás}

Az arXiv preprint szerverre például elsősorban fizikai, csillagászati, matematikai, számítástechnikai, biológiai, pénzügyi és statisztikai témájú publikációkat lehet feltölteni. Az oldal üzemeltetői nem végeznek lektorálási munkát, helyette moderátorként szürik az oda nem illő tartalmakat. A repozitóriumban egy kézirat több változata is szerepelhet, a szerző folyamatosan frissítheti a feltöltött anyagokat. Habár a legtöbb kézirat a feltöltést követően lektorálva is megjelenik neves szaklapokban, mégis vannak olyan szerzők, akik szerint a repozitóriumi közzététel hatékonyabb a folyóiratban történő publikálásnál, mert ugyanolyan szinten eléri a megfelelö szakmai közösségeket. ${ }^{18}$

Egyes szakirodalmi cikkek nyílt lektorálásként, mások a közlést megelőző értékelésként hivatkoznak erre a módszerre, a repozitóriumok müfaji sajátossága miatt azonban megkérdőjelezhető, hogy egy kalap alá vehetö-e ez a tevékenység a lektorálással.

\subsection{A lektorálással szemben megfogalmazott kritikák}

\section{Hosszú átfutási idő}

Kimondhatjuk, hogy a többlépcsős lektorálási rendszer időigényes és késlelteti a megjelenést. Arról nem is beszélve, hogy a vezető folyóiratoknál az az idősáv is hosszúnak bizonyul, amíg kiderül, hogy a kézirat befogadásra kerül-e vagy sem. A lektorálás teljes folyamata, beleértve a kézirat beküldését és elfogadását, majd a javításokat és módosításokat követő időszakot egészen a megjelenésig, akár egy

17 Michael Jubb: Peer review: The current landscape and future trends. In: The Association of Learned \& Professional Society Publisher vol. 29. pp. 18. 2016. https://bit.ly/3eIguLi

18 Hajnal Ward Judit: Ki szavatol a ...? Helyzetjelentés a tudományos lektorálás állásáról. In: Könyvtári Figyelő vol. 58. iss. 4. pp. 722-723. 2012. https://bit.ly/3cwkbAZ; 25 éves az Open Access mozgalom élharcosa - az arXiv.org. In: konyv.guru https://bit.ly/2Q86pNp 
évig is eltarthat. Ha figyelembe vesszük, hogy milyen gyorsan változnak egyes szakterületek kutatási eredményei és a tudomány finanszírozása - a versenytársak kutatásairól nem is beszélve - kifejezetten hosszú időnek számít az egy év. ${ }^{19}$

„Jelentős az eltérés a különböző tudományterületeken mind az átfutási idő,
mind pedig a visszautasítások számát illetően, amelynek okai közt említhető a
tanulmányok eltérö terjedelme mellett az is, hogy bizonyos tudományokban a
legfontosabb felfedezések mindössze néhány rangos lapban jelennek meg. Az
elfogadási arány és átfutási idő eltéréseiröl szólva megjegyzendö, hogy ugyan-
azon folyóiraton belül is lehetnek különbségek az egyes müfajokon belül, mint
például az új tudományos eredményeket közlő eredeti tanulmány (original ar-
ticle) vagy a szakirodalmat áttekintö összefoglaló tanulmány (review article)
közreadása között. Egyes cikktípusokat egyáltalán nem is lektoráltatnak, ilyen
például a vezércikk (editorial) vagy az olvasói levél."

\section{Hatékonyság}

A lektorálás után megjelent, majd különböző okokból visszavont cikkek számának emelkedése egyre inkább igazolja azt az állítást, hogy a lektorálás nem nyújt hatásos minőségi ellenőrzést, nem képes megakadályozni a hibás és hiányos kutatások közzétételét, az etikátlan magatartást, az esetleges korrupciót, továbbá nem biztosítja a kísérletek reprodukálhatóságát sem. ${ }^{21}$

\section{Elfogultság}

Akarva-akaratlanul, de az objektív bírálói véleményezés szinte lehetetlen. A nagyobb probléma abban az esetben jelentkezik, amikor a negatív vagy pozitív irányban megfogalmazott kritikák kedvezőtlen hatást gyakorolnak a tudományos publikálásra. Ezen a térenbefolyásoló tényezők a következők lehetnek: a szerzők személye, intézményi, esetleg nemi, etnikai hovatartozása, a származása, a bíráló viszonyulása a kutatott témához, vagy egyéb egyéni érdekeltsége a szerzővel szemben. ${ }^{22}$

Az elfogult értékítélet manipulálhatja a tudományos közéletet. A szakmai lektorálást kutató tanulmányok arról számolnak be, hogy az innovatív, a hagyományos megközelítésektől eltérő írások, vagy a

19 Hajnal Ward Judit: Ki szavatol a ...? Helyzetjelentés a tudományos lektorálás állásáról. In: Könyvtári Figyelő vol. 58. iss. 4. pp. 716-719. 2012. https://bit.ly/3cwkbAZ; Debra Dunn: The value and Process of Peer Review. In: AORN Journal. First published: 29 May $2018 \mathrm{https} / / / \mathrm{bit} . l y / 3 \mathrm{kUMOB}$

20 Uott.

21 Uott.

22 Uott. 
versenytárs kutatóintézet szerzőinek tollából származó kutatások óhatatlanul hátránnyal indulnak azokhoz a kéziratokhoz képest, amelyeket saját intézményének szerzője, vagy azonos kutatócsoportban tevékenykedö kolléga írt. ${ }^{23}$

\section{Szerzői manipulációk}

A szakmai bírálók sincsenek könnyű helyzetben, éppen ezért hiba lenne kizárólag őket felelősségre vonni. A szerzői visszaélések épp olyan gyakoriak, mint a bírálói oldalról elkövetett mulasztások. Csak hogy néhányat említsünk közülük: plagizálás, hivatkozásokkal történő manipuláció, kooperálás a predátor folyóiratokkal, adatok módosítása, szerzői társulások tényleges együttmüködés nélkül. ${ }^{24}$

\section{A lektorok kritikája}

Érdemes a szakirodalomból idézni néhány ismertebb kutatás eredményeit és ismert eseteket, amelyek jól példázzák a fentebb leírt kétségek valóságát.

A Retraction Watch becslése szerint 2015-ben néhány hónap alatt 260 publikációt vontak vissza olyan nemzetközi kiadók, mint az Elsevier, Sage és Springer. Az indok minden esetben az a feltételezés, hogy a szerzők kihasználták a lektorálási rendszer gyengeségeit. ${ }^{25}$ A lektori vélemények szubjektivitásra való hajlamosságát támasztja alá Fiske és Fogg tanulmánya - amire Hajnal Ward is hivatkozik -; ebben 153 cikk négyszáz bírálatát hasonlították össze. Az eredmény szerint csupán 0,44 százalékban találtak egyezéseket ugyanazon cikk bírálatai között. ${ }^{26}$

23 Michael Jubb: Peer review: The current landscape and future trends. In: The Association of Learned \& Professional Society Publisher vol. 29. pp. 15. 2016. https://bit.ly/3eIguLi; Mark Ware: Peer review: Recent Experience and Future Directions. In: New Review of Information Networking vol. 16. iss. 1. pp. 31. 2011. https://bit.ly/3rRrPwe; Hajnal Ward Judit: Ki szavatol a ...? Helyzetjelentés a tudományos lektorálás állásáról. In: Könyvtári Figyelő vol. 58. iss. 4. pp. 719-721. 2012. https://bit.ly/3cwkbAZ

24 Sipos Anna Magdolna: A folyóiratkrízisről. A szakfolyóiratok kiadási modelljének változásairól és áremelkedési tendenciáról könyvtáros szemmel. 1. rész. In: Könyvtári Figyelö vol. 63. iss. 1. pp. 11. 2017. https://bit.ly/3qHyHec

25 Michael Jubb: Peer review: The current landscape and future trends. In: The Association of Learned \& Professional Society Publisher vol. 29. pp. 15-16. 2016. https://bit.ly/3eIguLi

26 Michael Jubb: Peer review: The current landscape and future trends. In: The Association of Learned \& Professional Society Publisher vol. 29. pp. 15-16. 2016. https://bit.ly/3eIguLi 
Ceci és Peters kísérletükben 13 folyóirat lektorálási rendszerét vizsgálták a következő módszerrel. A folyóiratokhoz korábban megjelentetett cikkeket küldtek vissza úgy, hogy azokban módosításokat hajtottak végre. Megváltoztatták a szerzők nevét, az intézményi affiliációt kevésbé rangosra cserélték, kissé átírták az absztraktot vagy a szöveg bevezetőjét. (Csak 12 folyóirattal tudták végrehajtani a kísérletet, mert egy folyóirat időközben profilt váltott.) Az eredmények a következők lettek. 3 folyóirat ismerte fel, hogy korábban általuk közölt kéziratról van szó. Egy folyóirat fogadta el és akarta megjelentetni a publikációt. A maradék 8 a következő szempontokra hivatkozva elutasította a cikkeket: rosszul tervezettség, eredetiség hiánya, rossz statisztikai elemzés. ${ }^{27}$

Vannak szerzők, akik saját tapasztalataikat osztják meg. A Medical Care hasábjain az egyik szerző arról számolt be, hogy kéziratuk egyik bírálója egyértelmüen leereszkedő és becsmérlő hangnemben nyilatkozott a tanulmányukban kutatott fogyatékossággal élők csoportjáról, ezáltal megkérdőjelezve az interjúztatáson alapuló kutatás eredményeit. A folyóirat szerkesztősége elismerte, hogy a lektor stílusa sértő volt és felajánlotta a szerzőknek, hogy a szerkesztőségi rovatban írjanak az esetről. ${ }^{28}$

Hwang Woo-suk, dél-koreai őssejtkutató emberi sejtek sikeres klónozásáról publikált a Science folyóiratban, azonban a kutatási háttéranyagok későbbi felülvizsgálata során kiderült, hogy hamis adatokat felhasználva, a valóságnak nem megfelelő cikkeket írt. A botrány kitörését külföldi kollégája, Gerald Schatten indította el, aki elsőként kérte, hogy töröljék a nevét a publikációk szerzői listáiból. A cikkeket a folyóirat hiteltelenségük miatt visszavonta és létrehozott egy saját ad hoc bizottságot, amely megvizsgálta a publikálási rendszerüket, majd ezt követően szigorította a lektorálás folyamatát. Szintén az össejtkutatás területéröl ismert a STAP-botrány, ahol egy japán-amerikai szerzőpáros cikkeit kellett a Nature folyóiratnak visszavonnia adatok hamisítása és manipulálása miatt. A felelősség természetesen nem hárítható egy az egyben a lektorokra és a folyóiratok szerkesztőségére. A példa sokkal inkább azt érzékelteti, hogy a lektorálás nem jelent biztosítékot a csalók kiszürésére. ${ }^{29}$

27 Fenyvesi Tamás: Kettős vak lektorálás. In: Orvosi Hetilap vol. 143. iss. 5. pp. 248. 2002. https://bit.ly/3bR3ocG; Hajnal Ward Judit: Ki szavatol a ...? Helyzetjelentés a tudományos lektorálás állásáról. In: Könyvtári Figyelő vol. 58. iss. 4. pp. 721. 2012. https://bit.ly/3cwkbAZ

28 Lisa I. Iezzoni: Explicit Disability Bias in Peer Review. In: Medical Care vol. 56. iss. 4. pp. 277-278. 2018.

29 Bodnár János Kristóf, Gajdos Ágoston, Kakuk Péter: A Hvang-botrány következményei és tanulságai. In: Magyar Tudomány vol. 176. iss. 8. pp. 908. 2015. https://bit.ly/3vqXSoW; Rivalizálás lehet az össejtbotrány háttere. In: Index 2014.04.10. http://bit.ly/3lmZ9ZB; Nem úgy csalt az össejtkutató botrányhös. 


\subsection{A lecke ismeretlen fogalmainak magyarázata}

\section{The BMJ - British Medical Journal}

A British Medical Journal egy 1840-ben indított hetente megjelenö, lektorált, nemzetközi szinten elismert és vezető orvostudományi folyóirat. A BMJ 1999-ben vezette be a nyílt lektorálást.

\section{JAMA - The Journal of the American Medical Association}

A JAMA 1883 óta az American Medical Association gondozásában megjelenő, nemzetközi szinten elismert és vezető orvostudományi folyóirat.

\section{Kurrens szakirodalom}

Kurrens szakirodalomnak az éppen aktuálisan megjelenő vagy alig pár éve megjelent, még érvényben lévő kutatási eredményeket tartalmazó kiadványokat vagy publikációkat szokás nevezni.

\section{Lektor}

Adott tudományterület és/vagy szakterület kutatói, szakértői, akik szakmai szempontok alapján bírálják a folyóirat szerkesztőségbe beküldött kéziratokat. A lektor feladata, hogy felismerje ,a kéziratban közöltek eredetiségét" ${ }^{30}$ véleményezze a módszert és az „eredményekből levont következetések helyességét". ${ }^{31}$

\section{Lektorált folyóirat}

„Tudományosan lektorált folyóiratnak nevezzük azokat az időszaki kiadványokat, amelyek cikkeit a főfoglalkozású, szakmabeli és technikai szerkesztőkön kívül az adott szakterület legjavából válogatott szakmai lektorok minősítik, fogadják el közlésre, vagy esetleg utasítják el.”32

In: Index 2014.04.09. http://bit.ly/3rN34RP; Szégyenében öngyilkos lett az őssejtbotrányban érintett kutató. In: Index 2014.08.05. https://bit.ly/3eKR9QD

30 Fenyvesi Tamás: Kettős vak lektorálás. In: Orvosi Hetilap vol. 143. iss. 5. pp. 245. 2002. https://bit.ly/3bR3ocG

31 Tóth Réka: Kié a tudomány, és hogyan szerezzük meg? 2016. február 25. In: http://bit.ly/3cD0ZRX

32 Hajnal Ward Judit: Ki szavatol a ...? Helyzetjelentés a tudományos lektorálás állásáról. In: Könyvtári Figyelő vol. 58. iss. 4. pp. 713. 2012. https://bit.ly/3cwkbAZ 


\section{Public Library of Science - PloS}

Az egyik legkorábbi és legismertebb nemzetközi szinten elismert és vezető open access folyóirat kiadó.

\section{Preprint szerver}

„A preprint a digitális korszak előtt kialakult tipikus szürkeirodalom: kisebb példányszámban nyomtatott, szükebb körben terjesztett, az új eredményeket a hagyományos kiadást megelőző - vagy elkerülö -, gyors tájékoztatási forma. Tulajdonképpen a cikk első benyújtott (unrefereed), még nem elfogadott és nem lektorált változata(i). A szerver ebben a kontextusban az az informatikai eszköz, ami tárolja és szolgáltatja ezeket az összegyüjtött preprinteket." ${ }^{33}$

\section{Referált folyóirat}

„A dokumentációs ágazatokban referált folyóirat az a folyóirat, amelyiket egy másik folyóirat rendszeresen szemléz úgy, hogy közli az új lapszámok cikkeinek referátumát (összefoglalóját, rezüméjét, absztraktját), illetve az a folyóirat, amelyiket valamelyik indexelő szolgáltatás feldolgoz (Abstracting Journal; Indexing \& Abstracting Journal/Service). A referáló folyóirat célja, hogy a szakterületen megjelenő folyóiratok termését áttekinthetővé tegye, és megkönnyítse az új fejlemények, kutatási eredmények követését." ${ }^{34}$

\section{Referálás}

„A referálás azt a folyamatot jelenti, ahogyan az adott folyóirat közleményeit egy közösség számára elérhetővé teszik általában rövidített, kevésbé tudományos nyelven tömörített formában, amolyan izelítöként (ennek angol megfelelöje az abstracting)." ${ }^{{ }^{35}}$

33 Dudás Anikó: A tudományos kiadási eljárás kéziratváltozatainak terminológiája. In: Tudományos és Müszaki Tájékoztatás vol. 60. iss. 10-12. pp. 469 és 473474. 2013. https://bit.ly/3vqTFkZ

34 Uott, 468-469.

35 Hajnal Ward Judit: Ki szavatol a ...? Helyzetjelentés a tudományos lektorálás állásáról. In: Könyvtári Figyelő vol. 58. iss. 4. pp. 714. 2012. https://bit.ly/3cwkbAZ 


\section{Repozitórium}

„A repozitórium egyetemeken és kutatási intézményekben múködő dokumentumszerver, amely tudományos anyagok archiválására és világszerte díjmentes hozzáférhetővé tételére szolgál. Intézményi és diszciplináris repozitóriumokat különböztetünk meg." ${ }^{36}$

\section{Tudományos lektorálás}

„A tudományos lektorálás folyamata során a tanulmányt más, megfelelő szakértelemmel rendelkező kutatók értékelik. A tudományos lektorálás több lépcsőben és változatos módon zajlik. E folyamat közös eleme a közlésre benyújtott írás alapos vizsgálata előre megállapított tartalmi és formai kritériumok alapján (mint például a téma időszerüsége, a tudományos kutatás minősége, a szöveg tudományos nyelvi stílusa, a hivatkozások megfelelő volta stb.). A lektorálási szempontok alapvetően két kérdésre keresik a választ: mennyiben járul hozzá az adott kutatás a szakterület fejlödéséhez, és beleillik-e a közlemény a folyóirat arculatába tartalmilag és formailag." 37

\subsection{Felhasznált irodalom}

1. Hajnal Ward Judit: Ki szavatol a ...? Helyzetjelentés a tudományos lektorálás állásáról. In: Könyvtári Figyelő vol. 58. iss. 4. pp. 716-717. 2012. https://bit.ly/3cwkbAZ; Bodnár János Kristóf, Gajdos Ágoston, Kakuk Péter: A Hvang-botrány következményei és tanulságai. In: Magyar Tudomány vol. 176. iss. 8. pp. 908. 2015. https://bit.ly/3vqXSoW; Michael Jubb: Peer review: The current landscape and future trends. In: The Association of Learned \& Professional Society Publisher vol. 29. pp. 15. 2016. https://bit.ly/3eIguLi

2. Fenyvesi Tamás: Kettős vak lektorálás. In: Orvosi Hetilap vol. 143. iss. 5. pp. 245. 2002. https://bit.ly/3bR3ocG

3. Fenyvesi Tamás: Kettős vak lektorálás. In: Orvosi Hetilap vol. 143. iss. 5. pp. 245., pp. 247. 2002. https://bit.ly/3bR3ocG; Hajnal Ward Judit: Ki szavatol a ...? Helyzetjelentés a tudományos lektorálás állásáról. In: Könyvtári Figyelö vol. 58. iss. 4. pp. 719-720., pp. 716. 2012. https://bit.ly/3cwkbAZ

36 Repozitóriumok. Openscience.hu https://bit.ly/2OVQWzv

37 Hajnal Ward Judit: Ki szavatol a ...? Helyzetjelentés a tudományos lektorálás állásáról. In: Könyvtári Figyelő vol. 58. iss. 4. pp. 713-714. 2012. https://bit.ly/3cwkbAZ 
4. Fenyvesi Tamás: Kettős vak lektorálás. In: Orvosi Hetilap vol. 143. iss. 5. pp. 245., pp. 247. 2002. https://bit.ly/3bR3ocG; Hajnal Ward Judit: Ki szavatol a ...? Helyzetjelentés a tudományos lektorálás állásáról. In: Könyvtári Figyelő vol. 58. iss. 4. pp. 719-720., pp. 716. 2012. https://bit.ly/3cwkbAZ

5. Hajnal Ward Judit: Ki szavatol a ...? Helyzetjelentés a tudományos lektorálás állásáról. In: Könyvtári Figyelő vol. 58. iss. 4. pp. 719720., pp. 721. 2012. https://bit.ly/3cwkbAZ

6. Uott.

7. Fenyvesi Tamás: Kettős vak lektorálás. In: Orvosi Hetilap vol. 143. iss. 5. pp. 247. 2002. https://bit.ly/3bR3ocG; Debra Dunn: The value and Process of Peer Review. In: AORN Journal. First published: 29 May 2018 https://bit.ly/3lkUMOB

8. Michael Jubb: Peer review: The current landscape and future trends. In: The Association of Learned \& Professional Society Publisher vol. 29. pp. 16. 2016. https://bit.ly/3eIguLi

9. Fenyvesi Tamás: Kettős vak lektorálás. In: Orvosi Hetilap vol. 143. iss. 5. pp. 248. 2002. https://bit.ly/3bR3ocG

10. Michael Jubb: Peer review: The current landscape and future trends. In: The Association of Learned \& Professional Society Publisher vol. 29. pp. 16. 2016. https://bit.ly/3eIguLi

11. Debra Dunn: The value and Process of Peer Review. In: AORN Journal. First published: 29 May 2018 https://bit.ly/3lkUMOB

12. Fenyvesi Tamás: Kettős vak lektorálás. In: Orvosi Hetilap vol. 143. iss. 5. pp. 247-248. 2002. https://bit.ly/3bR3ocG

13. Hajnal Ward Judit: Ki szavatol a ...? Helyzetjelentés a tudományos lektorálás állásáról. In: Könyvtári Figyelő vol. 58. iss. 4. pp. 722. 2012. https://bit.ly/3cwkbAZ

14. Debra Dunn: The value and Process of Peer Review. In: AORN Journal. First published: 29 May 2018 https://bit.ly/3lkUMOB

15. Debra Dunn: The value and Process of Peer Review. In: AORN Journal. First published: 29 May 2018 https://bit.ly/3lkUMOB; Michael Jubb: Peer review: The current landscape and future trends. In: The Association of Learned \& Professional Society Publisher vol. 29. pp. 17. 2016. https://bit.ly/3eIguLi

16. Debra Dunn: The value and Process of Peer Review. In: AORN Journal. First published: 29 May 2018 https://bit.ly/3lkUMOB

17. Michael Jubb: Peer review: The current landscape and future trends. In: The Association of Learned \& Professional Society Publisher vol. 29. pp. 18. 2016. https://bit.ly/3eIguLi

18. Hajnal Ward Judit: Ki szavatol a ...? Helyzetjelentés a tudományos lektorálás állásáról. In: Könyvtári Figyelő vol. 58. iss. 4. pp. 722-723. 2012. https://bit.ly/3cwkbAZ; 25 éves az Open Access mozgalom élharcosa - az ar-Xiv.org. In: konyv.guru https://bit.ly/2Q86pNp

19. Hajnal Ward Judit: Ki szavatol a ...? Helyzetjelentés a tudományos lektorálás állásáról. In: Könyvtári Figyelő vol. 58. iss. 4. pp. 716-719. 
2012. https://bit.ly/3cwkbAZ; Debra Dunn: The value and Process of Peer Review. In: AORN Journal. First published: 29 May 2018 https://bit.ly/3lkUMOB

20. Uott.

21. Uott.

22. Uott.

23. Michael Jubb: Peer review: The current landscape and future trends. In: The Association of Learned \& Professional Society Publisher vol. 29. pp. 15. 2016. https://bit.ly/3eIguLi; Mark Ware: Peer review: Recent Experience and Future Directions. In: New Review of Information Networking vol. 16. iss. 1. pp. 31. 2011. https://bit.ly/3rRrPwe; Hajnal Ward Judit: Ki szavatol a ...? Helyzetjelen-tés a tudományos lektorálás állásáról. In: Könyvtári Figyelő vol. 58. iss. 4. pp. 719-721. 2012. https://bit.ly/3cwkbAZ

24. Sipos Anna Magdolna: A folyóiratkrízisröl. A szakfolyóiratok kiadási modell-jének változásairól és áremelkedési tendenciáról könyvtáros szemmel. 1. rész. In: Könyvtári Figyelő vol. 63. iss. 1. pp. 11. 2017. https://bit.ly/3qHyHec

25. Michael Jubb: Peer review: The current landscape and future trends. In: The Association of Learned \& Professional Society Publisher vol. 29. pp. 15-16. 2016. https://bit.ly/3eIguLi

26. Michael Jubb: Peer review: The current landscape and future trends. In: The Association of Learned \& Professional Society Publisher vol. 29. pp. 15-16. 2016. https://bit.ly/3eIguLi

27. Fenyvesi Tamás: Kettős vak lektorálás. In: Orvosi Hetilap vol. 143. iss. 5. pp. 248. 2002. https://bit.ly/3bR3ocG; Hajnal Ward Judit: Ki szavatol a ...? Hely-zetjelentés a tudományos lektorálás állásáról. In: Könyvtári Figyelő vol. 58. iss. 4. pp. 721. 2012. https://bit.ly/3cwkbAZ

28. Lisa I. Iezzoni: Explicit Disability Bias in Peer Review. In: Medical Care vol. 56. iss. 4. pp. 277-278. 2018.

29. Bodnár János Kristóf, Gajdos Ágoston, Kakuk Péter: A Hvangbotrány követ-kezményei és tanulságai. In: Magyar Tudomány vol. 176. iss. 8. pp. 908. 2015. https://bit.ly/3vqXSoW; Rivalizálás lehet az őssejtbotrány háttere. In: Index 2014.04.10. http://bit.ly/31mZ9ZB; Nem úgy csalt az őssejtkutató botrányhős. In: Index 2014.04.09. http://bit.ly/3rN34RP; Szégyenében öngyilkos lett az össejtbotrányban érintett kutató. In: Index 2014.08.05. https://bit.ly/3eKR9QD

30. Fenyvesi Tamás: Kettős vak lektorálás. In: Orvosi Hetilap vol. 143. iss. 5. pp. 245. 2002. https://bit.ly/3bR3ocG

31. Tóth Réka: Kié a tudomány, és hogyan szerezzük meg? 2016. február 25. In: http://bit.ly/3cD0ZRX

32. Hajnal Ward Judit: Ki szavatol a ...? Helyzetjelentés a tudományos lektorálás állásáról. In: Könyvtári Figyelő vol. 58. iss. 4. pp. 713. 2012. https://bit.ly/3cwkbAZ 
33. Dudás Anikó: A tudományos kiadási eljárás kéziratváltozatainak terminológi-ája. In: Tudományos és Müszaki Tájékoztatás vol. 60. iss. 10-12. pp. 469 és 473-474. 2013. https://bit.ly/3vqTFkZ

34. Uott, 468-469.

35. Hajnal Ward Judit: Ki szavatol a ...? Helyzetjelentés a tudományos lektorálás állásáról. In: Könyvtári Figyelő vol. 58. iss. 4. pp. 714. 2012. https://bit.ly/3cwkbAZ

36. Repozitóriumok. Openscience.hu https://bit.ly/2OVQWzv

37. Hajnal Ward Judit: Ki szavatol a ...? Helyzetjelentés a tudományos lektorálás állásáról. In: Könyvtári Figyelö vol. 58. iss. 4. pp. 713-714. 2012. https://bit.ly/3cwkbAZ

\section{6. Összefoglalás}

Egy kutatási eredmény publikálása nem könnyü feladat. A publikáció megírásától a folyóirat kiválasztásán át egészen a publikáció megjelentetéséig számos akadállyal kell szembesülnie a szerzőknek. A tudományos folyóirat-kiadásban végbemenő változások - melyek egy részét az előző leckékben részleteztünk -, a szakmai lektorálást is utolérték. A felhasználói oldalról egyre nagyobb igény fogalmazódik meg az átláthatóság iránt. Ennek okai elsősorban a visszaélésekben és a hatékonyság hiányában keresendőek. A hagyományos értelemben vett zárt lektorálás mellett megjelentek az új szemléletet képviselő módszerek is. A nyílt lektorálás például néhány folyóiratnál már bevett eljárásként van jelen. A szakmai lektorálást ért kritikai észrevételek egyelőre leginkább a lektorálás típusainak differenciálódásához vezettek. Jelenleg azonban még kérdéses, hogy a szakmai közösségek által kiváltott változások hosszútávon milyen hatást tudnak majd elérni.

\section{7. Önellenőrző kérdések}

Sorolja fel a lektorálás típusait!

Zárt lektorálás (single blind, double blind), nyílt lektorálás, collaborative peer review, transferable peer review, post publication peer review, szakmai moderálás

Nevezze meg a két leggyakoribb lektorálási típust!

Single blind peer review, double blind peer review 
Ismertesse a zárt típusú lektorálás két fajtájának jellemzöit!

A válasz a lecke II.1.1.a. Single blind peer review és a II.1.1.b. Double blind peer review címü bekezdésében található.

Ismertesse a nyilt lektorálás jellemzőit!

A válasz a II.2.1. Nyílt lektorálás című bekezdésben található.

Sorolja fel, hogy milyen kritikák fogalmazódtak meg

a lektorálás rendszerével szemben!

A válasz a lecke 4.3. A lektorálással szemben megfogalmazott kritikák címü bekezdésében található.

Ki az a lektor és mi a feladata?

Adott tudományterület és/vagy szakterület kutatói, szakértői, akik szakmai szempontok alapján bírálják a folyóirat szerkesztőségbe beküldött kéziratokat. A lektor feladata, hogy felismerje ,a kéziratban közöltek eredetiségét” véleményezze a módszert és az „eredményekből levont következtetések helyességét".

\section{Mi az a lektorált folyóirat?}

„Tudományosan lektorált folyóiratnak nevezzük azokat az időszaki kiadványokat, amelyek cikkeit a főfoglalkozású, szakmabeli és technikai szerkesztőkön kívül az adott szakterület legjavából válogatott szakmai lektorok minősítik, fogadják el közlésre, vagy esetleg utasítják el.”

\section{Mi az a tudományos lektorálás?}

„A tudományos lektorálás folyamata során a tanulmányt más, megfelelő szakértelemmel rendelkező kutatók értékelik. A tudományos lektorálás több lépcsőben és változatos módon zajlik. E folyamat közös eleme a közlésre benyújtott írás alapos vizsgálata előre megállapított tartalmi és formai kritériumok alapján (mint például a téma időszerüsége, a tudományos kutatás minősége, a szöveg tudományos nyelvi stílusa, a hivatkozások megfelelő volta stb.). A lektorálási szempontok alapvetően két kérdésre keresik a választ: mennyiben járul hozzá az adott kutatás a szakterület fejlödéséhez, és beleillik-e a közlemény a folyóirat arculatába tartalmilag és formailag." 


\subsection{Tesztkérdések}

\section{Melyik a kakukktojás?}

[ ] Kettős vak lektorálás

[ ] Collaborative peer review

[•] Szakmai moderálás

[ ] Transferable peer review

\section{Mi a nyilt lektorálás célja?}

[ ] Hogy a szerző számon tudja kérni a szakmai bírálót, ha elégedetlen.

[•] Átláthatóság, alaposabb véleményezés, fokozottabb elszámolhatóság.

[ ] Az olvasók is hozzá tudjanak szólni.

[ ] Hogy a fiatal bírálók is lehetőséget kapjanak.

\section{Mi a tudományos lektorálás célja?}

[ ] A hivatkozások hitelességének ellenőrzése.

[ ] A tudományos lektorálás megegyezik a szerkesztői munkával.

[ ] A helyesírás és szerkesztési hibák javítása.

[•] A publikációk szakmai szintü, jobbító szándékú véleményezése meghatározott szempontok alapján.

4. Folytassa a definíciót: A tudományosan lektorált folyóirat cikkeit...

[•] ...szakmai lektorok minősítését követően publikálják.

[ ] ...kurrens szakirodalomnak nevezzük.

[ ] ...repozitóriumban örzik.

[ ] ...egy másik folyóirat szemlézi. 